\title{
The Apoptosis-inducing Antiproliferative Activity and Quantitative Phytochemical Profiling of Polyphenol-rich Part of Leea Aequata L. Leaves
}

\section{Md. Golam Mostofa}

University of Rajshahi

\section{A. S.M. Ali Reza}

International Islamic University Chittagong

\section{Zidan Khan}

International Islamic University Chittagong

\section{Toshifumi Tsukahara}

Japan Advanced Institute of Science and Technology

AHM Khurshid Alam ( $\nabla$ khurshid.jaist@gmail.com )

University of Rajshahi

Md Golam Sadik

University of Rajshahi

\section{Research Article}

Keywords: Leea aequata, antioxidant, oxidative stress, free radical, cytotoxicity, anticancer

Posted Date: September 1st, 2021

DOI: https://doi.org/10.21203/rs.3.rs-830741/v1

License: (9) (i) This work is licensed under a Creative Commons Attribution 4.0 International License.

Read Full License 


\section{Abstract}

Aim/Objectives: Oxidative stress (OS) caused by the accumulation of free radicals in the body triggers many life-threatening diseases, including cancer. Plants are the rich source of safe and effective medicinal compounds like antioxidants that can prevent OS by scavenging free radicals. The aim of this study was to explore the chemical compositions of the methanolic extract of Leea aequata L. leaves possessed the highest antioxidant and cytotoxic activities.

Methods and Materials: The Leea aequata leaves (LAL) was extracted with $80 \%$ methanol and the crude methanolic extract of LAL (CME) was successively fractionated with petroleum ether, chloroform, ethyl acetate and finally with water to get petroleum ether (PEF), chloroform (CHF), ethyl acetate (EAF) and aqueous (AQF) fraction, respectively. The antioxidant activity was evaluated by the in vitro standard spectrophotometric methods. The MTT colorimetric method was used to measure cytotoxic activity. Apoptosis was measured using fluorescein annexin V-FITC/PI staining method. GC-MS was used to investigate phytochemical compositions.

Results: Among the fractions, the highest phenolic and flavonoid-rich fraction was EAF, which contained $267.05 \pm 8.53 \mathrm{mg}$ of gallic acid equivalent (GAE) and $152.98 \pm 1.96 \mathrm{mg}$ of catechin equivalent (CAE)/gm of dried extract, respectively. The EAF was found to be the highest antioxidant and reducing power activities. Also, EAF had the strongest free radical scavenging activity with $\mathrm{IC}_{50}$ values of $5.11,36.54$ and 38.96 $\mu \mathrm{g} / \mathrm{mL}$ for DPPH, hydroxyl and lipid peroxide free radicals, respectively. Moreover, EAF significantly reduced the HeLa cell proliferation and it was due to the induction of apoptosis of HeLa cells.

Furthermore, GC-MS data revealed that EAF contained 17 compounds. Methyl esters of long chain fatty acid were the major chemical constituents. Interestingly, hexadecanoic acid, methyl ester; 9-octadecenoic acid (Z)-, methyl ester; 9,12-octadecadienoic acid, methyl ester (Z, Z) and phenol, 2,4-bis(1,1dimethylethyl) are known to be antioxidant and cytotoxic. Antioxidant and anti-cancer activity were significantly correlated with the total content of phenolics and flavonoids, suggest that the fractions could be the good source of antioxidant and anti-cancer agents.

Conclusion: The EAF of Leea aequata has strong polyphenolic content compared to the other fractions. The cytotoxic and antioxidant activity of Leea aequata were due to the presence of different bioactive compounds.

\section{Background}

Living organisms continuously produce reactive oxygen species (ROS) during normal cellular metabolism [1]. At a low or moderate concentration, ROS can play some vital roles in that living organisms like synthesize some essential cellular structures, make stronger defense systems to protect from pathogens, act as a messenger of cell-to-cell, and is essential for the normal neural activity [2]. On the other hand, at a higher concentration, ROS can demolish and modify the many essential macromolecules like DNA, RNA, lipids, and proteins. Most potent reactive molecules can be generated by these modifications [3]. 
The lack of balance between generation and scavenging of free radicals by antioxidant is termed as oxidative stress (OS) [1]. Diet, smoking, concurrent disease status (e.g., diabetes), alcohol consumption, pollution, genetic composition, age, menopausal status, gender etc. are the major risk factors of OS development [4]. OS is responsible for many life-threatening conditions, including cancer and many other diseases [1]. According to the WHO (2018), globally cancer is the second leading cause of death which is responsible for 1 out of 6 deaths [5]. Around 9.6 million deaths were caused by cancer in 2018 [6]. The prevalence of cancer is increasing day by day. Current treatment options for cancer have some limitations. These drugs are highly toxic for both normal and cancer cells and thus cause health related other serious complications [7]. That's why searching a novel anticancer drug is an urgent need, which has no harmful effect on normal cells and cures cancer [8]. Cytotoxic drugs are the main treatment option for some types of cancer [9]. They are very effective for fast proliferating cancer like leukemia and lymphomas [3]. They kill cancer cells by damaging DNA and microtubules [10]. Many polyphenols include flavonoids, alkaloids, saponins, cardiac glycoside, and fatty acids were reported to have cytotoxic properties $[1,3,6,11]$. The previous study showed that ROS scavenger can be used to suppress the cancer cells proliferation as ROS is responsible for the development, growth and proliferation of cancer cells [6]. Antioxidants can protect the cells from cancer and reduce the risks of cancer. Numerous studies reported that nutraceuticals rich in antioxidants killed cancer cells by showing pro-oxidative activity [12]. Antioxidants are the compounds, which are able to delay, prevent or cure the oxidative damage by the presence of it at lower concentration compared to that of the free radicals [13]. They play an important role to scavenge the free radicals, stop the propagation of free radical chain reaction and terminate the chain reaction. Phenolic and aromatic ring containing antioxidants are the most effective antioxidants as they can release $\mathrm{H}^{\circ}$ to stabiles the radical intermediate in free radical chain reaction [14]. Antioxidants protect living organisms by reducing OS, DNA mutation, malignant transformation, and other parameters of cell damage [15].

Recently, some toxicological studies reported that synthetic antioxidants are not a good source of antioxidants as they show unwanted or adverse side effects. Researchers are more interested in natural antioxidant sources due to easily available, economic, and non-toxic. Polyphenolic compounds are the main constituents of natural sources [16]. Therefore, antioxidant-enriched botanical supplements can confer protection by decreasing OS and inflammatory processes [17, 18]. Over 8,000 polyphenolic compounds and more than 6,000 flavonoids are reported in various plants. Most of the flavonoids showed the most powerful antioxidant activity $[13,19,20]$. Nature provides the major portion of anticancer drugs. Total 136 drugs were recorded as anticancer drugs in the world over the period from 1981 to 2014 . Surprisingly, $83 \%$ of these anticancer drugs were natural sources [21]. For instance, drugs derived from plant compounds are curcumin (diferuloylmethane) [22] and paclitaxel which is a taxane dipertene present in the crude extract obtained from the bark of Taxus brevifolia Nutt [23]. Another example is Taxol (essentially all taxanes), which hinders microtubule disassembly by joining the microtubules that have been polymerized [23]. Moreover, pomiferin, an isoflavone isolated from Osage orange (Maclura pomifera), and sulforaphane, an isothiocyanate isolated from broccoli, have recently been identified to possess anticancer properties via HDACi [24]. Thymoquinone has been reported to have 
potent anticancer and superoxide anion scavenging abilities in animal models and cell culture systems [25]. The thymoquinone has been isolated from seed of Nigella sativa.

Leea aequata ( $L$. aequata) is a traditional medicinal plant belongs to the family of Leeaceae [26]. It is widely distributed in Bangladesh, Bhutan, Cambodia, China, India, Malaysia, Myanmar, Nepal, Philippines, Thailand, and Vietnam [27]. In Bangladesh, it is distributed in the forest of Chittagong and Sylhet [28]. It contains phenolics, flavonoids, saponin, tannins, glycosides, and steroids [7, 29]. L. aequata is used for treating carbuncle, gastric tumour, hydrocele, rheumatism, ureterolithiasis, vertigo, vomiting, bronchitis, dyspepsia, itching, leprosy and tuberculous ulcers [28]. Traditionally, the roots, tubers and stems are used as mucilaginous and astringent [30]. The barks and roots are used to treat indigestion, jaundice, chronic fever and malaria as astringent and anthelmintic [31]. The leaves and thigh are used as antiseptic and wound healing agent [30]. The paste of fresh leaves is externally used to treat skin disease and wound [27]. The essential oil obtained from the whole plant by steam distillation is traditionally used to treat tuberculosis [30]. Recent studies revealed that the seeds, stems and roots possessed antibacterial activity [7]. The leaves have anticonvulsant, antinociceptive and anthelmintic activity $[28,31]$. The $L$. aequata has widely been used by local practitioner against various diseases which encouraged us to carry out the pharmacological activity of this plant in this study. In this study, we investigated the in vitro antioxidant and cytotoxic activity of the different fractions of $L$. aequata leaves (LAL). We also explored the chemical profiling of the most effective antioxidant and cytotoxic fraction.

\section{Materials And Methods}

\section{Collection and Identification of Plant}

Leaves of Leea aequata L. (L. aequata), LAL, were collected from Sylhet, Bangladesh, in November 2017 and were identified by an expert taxonomist at Bangladesh National Herbarium where a voucher specimen (DACB Accession Number 45396) was deposited.

\section{Preparation of Plant's Leaves}

Collected leaves were washed properly with fresh tap water to remove dirty materials followed by shade dried for several days with occasional sun drying. These were then dried in an oven for 24 hours at considerably low temperature for better grinding. The dried materials were ground into coarse powder by a grinding machine in the Department of Pharmacy, University of Rajshahi, Bangladesh and stored at room temperature for future use.

\section{Extraction of Plant's Leaves}

The dried powdered of LAL (about $500 \mathrm{gm}$ ) were taken in an amber-coloured extraction bottle (2.5 litres capacity) and soaked the leaves with $100 \%$ methanol ( $1 \mathrm{~L} \times 3$ times). The sealed bottle was shaken and 
stirred occasionally. The final extract was filtered separately through cotton and then Whatman No.1 filter papers followed by concentrated with a rotary evaporator (Bibby Sterlin Ltd, UK) under vacuum pressure at $45^{\circ} \mathrm{C}$ to afford $80 \mathrm{gm}$ leaves extract. A solution of an aliquot $(35 \mathrm{gm})$ of extract in methanol and water was fractionated by pet-ether, chloroform and ethyl acetate to get petroleum ether (PEF, $4.86 \mathrm{gm}$ ), chloroform (CHF, $3.79 \mathrm{gm})$, ethyl acetate $(E A F, 9.45 \mathrm{gm})$ and aqueous ( $A Q F, 15.1 \mathrm{gm})$ fractions.

\section{Determination of Antioxidant Compounds}

\section{Determination of Total Phenolic}

The content of total phenolic of different extractives was determined according to the method described by Wolfe et al., 2003 [32] in which Folin-ciocalteu reagent (FCR) was used as oxidizing agent and gallic acid (GA) was used as standard. Briefly, $0.4 \mathrm{~mL}$ of plant extract / standard of different concentrations were mixed with $2 \mathrm{~mL}$ of FCR (diluted 10 times with deionized water) reagent solution in different test tubes. After adding $3 \mathrm{~mL}$ of sodium carbonate $(7.5 \%)$ solution, the test tubes were incubated for 30 minutes at $25^{\circ} \mathrm{C}$ to complete the reaction. Then the absorbance of the solution of each test tube was recorded at $760 \mathrm{~nm}$ using a spectrophotometer against blank. The total content of phenolic compounds in different extracts was expressed as mg of gallic acid equivalent (GAE) per gram of dry extract and calculated using the calibration curve equation, $y=0.102 x+0.0268\left(R^{2}=0.9996\right)$ by the formula, $C=$ $(x \times V) / M$. Where, $C$ is total content of phenolic compounds as $m g$ of GAE in each gram of dried extract, $x$ is GAE concentration in $\mathrm{mg} / \mathrm{mL}$ present in that particular sample concentration, $\mathrm{V}$ is final volume of the solution in $\mathrm{mL}$ and $\mathrm{M}$ is mass of the sample in final solution in $\mathrm{gm}$.

\section{Determination of Total Flavonoids}

The content of total flavonoids of different extractives was determined by colorimetric method [13] using Catechin (CA) as standard. Briefly, $0.5 \mathrm{~mL}$ of plant extract / standard of different concentrations was mixed with $150 \mu \mathrm{L}$ of $5 \%$ sodium nitrate and $2.5 \mathrm{~mL}$ of distilled water in different test tubes and incubated for $5 \mathrm{~min}$ at room temperature (RT). $0.3 \mathrm{~mL}$ of $10 \% \mathrm{AlCl}_{3}$ was added in each test tube and incubated for 6 min at RT. $1 \mathrm{~mL}$ of $4 \% \mathrm{NaOH}$ was added to the mixture and incubated at RT for 15 minutes to complete the reaction. Then the absorbance of the solution of each test tube was measured at $510 \mathrm{~nm}$ using a spectrophotometer against blank. The total content of flavonoid compounds in different extracts was calculated as catechin equivalent (CAE) per gm of dry extract from the standard curve equation, $y=0.0264 x-0.038, R^{2}=0.9994$ by the formula, $C=(x \times V) / M$. Where, $C$ is total content of flavonoids compounds as $\mathrm{mg}$ of CAE in each gram of dried extract, $x$ is CAE concentration in $\mathrm{mg} / \mathrm{mL}$ present in that particular sample concentration, $\mathrm{V}$ is final volume of the solution in $\mathrm{mL}$ and $\mathrm{M}$ is mass of the sample in final solution in gm. 


\section{In vitro Antioxidant Assay}

\section{Determination of Total Antioxidant Capacity}

The total antioxidant capacity of different extractives was determined according to Prieto et al., 1999 [33] with some modifications. $0.5 \mathrm{~mL}$ of plant extract / standard of different concentrations was mixed with $3 \mathrm{~mL}$ of reaction mixture containing $0.6 \mathrm{M}$ sulphuric acid, $28 \mathrm{~mm}$ sodium phosphate and $1 \%$ ammonium molybdate and then incubated at $95^{\circ} \mathrm{C}$ for 10 minutes to complete the reaction. The absorbance of the solution of each test tube was measured at $695 \mathrm{~nm}$ using a spectrophotometer against blank after cooling at RT. Increased absorbance of the reaction mixture indicates increased total antioxidant capacity. In this study, standard/samples at five different concentrations ranging from 12.5 to $150 \mu \mathrm{g} / \mathrm{mL}$ were taken for each antioxidant assay. Concentrations were selected on the basis of trial and error to fit the range of concentration that can fully represent the rational change of antioxidant activity with the increasing concentration of the samples. The experiment was repeated three times at each concentration.

\section{Ferric Reducing Power Capacity}

The total antioxidant capacity of different extractives was estimated as described Oyaizu 1986 [34]. 0.25 $\mathrm{mL}$ of plant extract / standard of different concentrations was mixed with $0.625 \mathrm{~mL}$ of potassium buffer $(0.2 \mathrm{M}, \mathrm{pH} 6.6)$ and $0.625 \mathrm{~mL}$ of $1 \%$ potassium ferricyanide $\left[\mathrm{K}_{3} \mathrm{Fe}(\mathrm{CN})_{6}\right]$, and incubated for $20 \mathrm{~min}$ at $50^{\circ} \mathrm{C}$ to complete the reaction. $0.625 \mathrm{~mL}$ of $10 \%$ TCA was added in each of different test tubes and centrifuged at $3000 \mathrm{rpm}$ for $10 \mathrm{~min} .1 .8 \mathrm{~mL}$ supernatant was withdrawn from each test tube and mix with $1.8 \mathrm{~mL}$ of distilled water followed by the addition of $0.36 \mathrm{~mL}$ of $0.1 \%$ ferric chloride $\left(\mathrm{FeCl}_{3}\right)$ solution to each diluted reaction mixture. Finally, the absorbance of each sample and standard was measured at $700 \mathrm{~nm}$ using a spectrophotometer against blank.

\section{DPPH (1,1-diphenyl-2-picrylhydrazyl) Radical Scavenging Assay}

The free radical-scavenging ability of the extracts/standard was tested using the DPPH radicalscavenging assay as described by Blois [35] and Desmarchelier et al. [36]. Briefly, $2.4 \mathrm{~mL}$ of methanol solution of $0.1 \mathrm{mM}$ DPPH was mixed with $1.6 \mathrm{~mL}$ of plant extracts / standard dissolved in methanol at different concentrations and incubated at RT for 30 minutes in a dark place to complete the reaction. Then absorbance for test and standard solutions was measured at $517 \mathrm{~nm}$ using a spectrophotometer. A typical blank solution contained the same solution mixture without plant extracts and/or standard and it was incubated under the same conditions as the rest of the sample solution. The percentage (\%) scavenging activity of DPPH radicals was calculated from the following equation: 


\section{$\% I=\{(A c-A s) / A c\} \times 100$}

Where, Ac is absorbance of the control, As is absorbance of the extract / standard. Then all the \% scavenging was plotted against concentration and $\mathrm{IC}_{50}$ was calculated.

\section{Hydroxyl Radical Scavenging Assay}

The hydroxyl radical-scavenging activity of the extracts/standard was determined by the method as described by Halliwell and Gutteridge [37]. Hydroxyl radical was generated by the Fe3+ascorbate-EDTA- $\mathrm{H}_{2} \mathrm{O}_{2}$ system (Fenton reaction). The assay is based on the quantification of the 2-deoxyD-ribose degradation product, which forms a pink chromogen upon heating with TBA at low $\mathrm{pH}$. The reaction mixture contained $0.8 \mathrm{~mL}$ of phosphate buffer solution ( $50 \mathrm{mmol} \mathrm{L}-1, \mathrm{pH} 7.4), 0.2 \mathrm{~mL}$ of extracts/standard at different concentrations $(6.25-100 \mu \mathrm{g} / \mathrm{mL}), 0.2 \mathrm{ml}$ of EDTA (1.04 mmol L-1), $0.2 \mathrm{ml}$ of FeCl3 ( $1 \mathrm{mmol} \mathrm{L}-1)$, and $0.2 \mathrm{ml}$ of 2-deoxy-D-ribose ( $28 \mathrm{mmol} \mathrm{L-1})$ was taken in the test tubes. The mixtures were kept in a water bath at $37^{\circ} \mathrm{C}$ and the reaction was started by adding $0.2 \mathrm{ml}$ of $A A(2 \mathrm{mmol}$ $\mathrm{L}-1)$ and $0.2 \mathrm{ml}$ of $\mathrm{H}_{2} \mathrm{O}_{2}(10 \mathrm{mmol} \mathrm{L}-1)$. After incubation at $37^{\circ} \mathrm{C}$ for $1 \mathrm{~h}, 1.5 \mathrm{ml}$ of TBA ( $\left.10 \mathrm{~g} \mathrm{~L}-1\right)$ was added to the reaction mixture followed by adding $1.5 \mathrm{ml}$ of $\mathrm{HCl}(25 \%)$. The mixture was heated at $100{ }^{\circ} \mathrm{C}$ for $15 \mathrm{~min}$ and then cooled down with water. The absorbance of solution was measured at $532 \mathrm{~nm}$ with a spectrophotometer. The hydroxyl radical scavenging activity was evaluated with the inhibition percentage of 2-deoxy-D-ribose oxidation on hydroxyl radicals. The percentage of HRSA (\%HRSA) was calculated according to the following formula:

The percentage (\%) scavenging activity of $\mathrm{HO}$ - radicals was calculated from the following equation:

\section{$\%$ hydroxyl radical-scavenging activity $=\{($ Ac-As $) / A c\} \times 100$}

Where, $\mathrm{Ac}=$ Absorbance of the control, As= Absorbance of the extract/ standard. At the concentrations ranged from 6.25 to $100 \mu \mathrm{g} / \mathrm{mL}$, the range of the absorbance values of the samples was $0.068-3.478$, respectively. The experiment was repeated three times at each concentration.

\section{In vitro Biological Studies on L. aequata}

\section{Lipid Peroxidation Inhibition Assay}

The degree of lipid peroxidation was assayed by estimating the Thiobarbituric Acid Reactive Substances (TBARS) by using the standard method as described by Haenen and Bast 1983 [36]. The adult long Swiss albino mice weighing about $35 \mathrm{gm}$ was anesthetized with chloroform. The excised mice livers were homogenized with a homogenizer in an ice-cold phosphate buffer $(50 \mathrm{~mm}, \mathrm{pH} 7.4)$ to produce a 1/10 homogenate. The homogenate was centrifuged at $12,000 \mathrm{rpm}$ for $15 \mathrm{~min}$ at $4^{\circ} \mathrm{C}$. The supernatant was 
used as liposome for in vitro lipid peroxidation assay. $0.5 \mathrm{~mL}$ of supernatant and $0.3 \mathrm{~mL}$ of extract / standard at different concentrations were mixed with $1 \mathrm{~mL}$ of $0.15 \mathrm{M} \mathrm{KCl}$ and $200 \mu \mathrm{L}$ of $0.4 \mathrm{mM} \mathrm{FeCl}_{3}$ and put in the incubator at $37^{\circ} \mathrm{C}$ for 30 minutes. After that, $2 \mathrm{~mL}$ of ice-cold TBA-TCA-HCl-BHT solution was immediately added to each test tube to stop the reaction and then heated at $90^{\circ} \mathrm{C}$ for 60 minutes. After cooling on ice and centrifugation at $3000 \mathrm{rpm}$ for $5 \mathrm{~min}$, the supernatants were removed and the absorbance of supernatants was measured on a spectrophotometer at $532 \mathrm{~nm}$. A control experiment was performed in the presence of distilled water without the extract and / or standard. The percentage (\%) scavenging activity of lipid peroxide radicals was calculated from the equation,

\section{$\% I=\{($ Ac-As $) / A c\} \times 100$}

Where, Ac is absorbance of the control, As is absorbance of the extract / standard. Then \% of scavenging was plotted against concentration and $\mathrm{IC}_{50}$ was calculated.

\section{Cytotoxicity Screening}

\section{Cell Culture}

HeLa (cervical cancer cell) cells were purchased from American Type Culture Collection, USA. The cells were routinely cultured in Dulbecco's modified Eagle's medium (DMEM) supplemented with $10 \%$ fetal bovine serum in an atmosphere with $5 \% \mathrm{CO}_{2}$ at $37^{\circ} \mathrm{C}$. Exponential-growth cells were used in all the experiments.

\section{Cell proliferation assay}

Cell proliferation was assessed using the MTT assay as described by $[3,10]$. Briefly, $5 \times 10^{3}$ cells were incubated in 96-well plates in the presence of various concentrations of the fractions for $48 \mathrm{~h}$. At the end of the treatment, $20 \mu \mathrm{L}$ MTT ( $5 \mathrm{mg} / \mathrm{mL}$ dissolved in PBS) was added to each well and incubated for an additional $4 \mathrm{~h}$ at $37^{\circ} \mathrm{C}$. The purple-blue MTT formazan precipitate was dissolved in $200 \mu \mathrm{L}$ of DMSO and the optical density was measured at $570 \mathrm{~nm}$ using microplate reader (Varioskan Flash 2.4.3., Thermo Fisher Scientific) and percentage of cell viability was calculated by using the following formula: OD of samples/OD of controlsX100.

\section{Measurement of Apoptosis of EAF}

DAPI, annexin V-FITC and PI triple fluorescence staining for cancer cell apoptosis measurement were performed according to the method as described by Rahman et al., 2021 [10]. Briefly, HeLa cells were cultured in medium containing $100 \mathrm{nM}$ samples. After $48 \mathrm{~h}$ treatment, the cells were washed twice with 
$0.01 \mathrm{M}$ PBS and suspended in $200 \mu \mathrm{L}$ binding buffer. The cells were then incubated with $10 \mu \mathrm{L} \mathrm{DAPI}, 10$ $\mu \mathrm{L}$ annexin V-FITC and $5 \mu \mathrm{L} \mathrm{PI}$ for 30 min at $4^{\circ} \mathrm{C}$ in the dark. DAPI, annexin V-FITC and PI fluorescence were immediately observed under an FV1000 confocal laser scanning microscope (Olympus, Tokyo, Japan).

\section{GC-MS Analysis of EAF}

The bioactive compounds from the EAF were analyzed using the GC-MS with electron-impact ionization (EI) on a gas chromatograph (GC-17A, Shimadzu Corporation, Kyoto, Japan) coupled to a mass spectrometer (GC-MS TQ 8040, Shimadzu Corporation). A fused silica capillary column (Rxi-5 ms; 0.25-m film, 30-m long, 0.32-mm internal diameter) coated with DB-1 (J\&W) was used. The inlet temperature was $260^{\circ} \mathrm{C}$ and the oven temperature was set at $70^{\circ} \mathrm{C}(0 \mathrm{~min}) ; 10^{\circ} \mathrm{C}, 150^{\circ} \mathrm{C}(5 \mathrm{~min}) ; 12^{\circ} \mathrm{C}, 200^{\circ} \mathrm{C}(15 \mathrm{~min})$; and $12^{\circ} \mathrm{C}, 220^{\circ} \mathrm{C}$ (5 min) with a hold time of $10 \mathrm{~min}$. The flow rate of the column was $0.6 \mathrm{~mL} / \mathrm{min}$ helium gas at a constant pressure of $90 \mathrm{kPa}$. The aux (GC to MS interface) temperature was $280^{\circ} \mathrm{C}$. The MS was set to scan mode with a scanning range of 40-350 amu, while the ionization mode was El type and the mass range was set within $50-550 \mathrm{~m} / \mathrm{z}$. The sample $(3 \mu \mathrm{L})$ was injected in split fewer modes. The total GC-MS run time was set for 29.33 min and compounds in the peak areas were identified by comparison with those in the database of the GC-MS library version NIST 08-S.

\section{In silico Molecular Docking}

\section{Protein Preparation}

The 3D crystal structures of Caspase 3 (PDB: 5IAE) for HeLa [38, 39], structure of EGFR kinase domain (PDB: 2ITY) [40], glutathione reductase (PDB: 3GRS) [41], and urate oxidase (PDB: 1R4U) [42] were downloaded in PDB format from Protein Data Bank [43]. Then, the structures were prepared and refined through the process as described by Uddin et al[44, 45].

\section{Ligand Preparation}

Isolated compounds from EAF were collected from Pubchem databases in SDF format. The 3D configuration for these was built by using Ligprep wizard in Maestro Schrödinger (v11.1) with an OPLS3 [46] force field. Their ionization states were generated at pH $7.0 \pm 2.0$ using Epik in Schrödinger Suite. Up to 32 possible stereoisomers per ligand were retained.

\section{Receptor Grid Generation}


Receptor grids were calculated for prepared proteins so that various ligand poses bind within the predicted active site during docking. In Glide, Van der Waals radius scaling factor is 1 and the partial charge cutoff is 0.25 , which are default parameters. A cubic box of specific dimensions centered on the centroid of the active site residues (Reference ligand active site) was generated for receptor. The bounding box was set to $14 \AA \times 14 \AA$ × $14 \AA$ for docking experiments.

\section{Glide Standard Precision (SP) Ligand Docking}

SP flexible ligand docking was carried out in the Glide of Schrödinger-Maestro (v11.1) $[44,47,48]$ within which penalties were applied to non-cis/trans amide bonds. Van der Waals scaling factor and partial charge cutoff was selected to be 0.80 and 0.15 , respectively for ligand atoms. Final scoring was performed on energy-minimized poses and displayed as glide score. The best docked pose with the lowest glide score value was recorded for each ligand.

\section{In Silico Determination of Pharmacokinetic Parameters by SwissADME}

The pharmacokinetic parameters or drug-likeness properties of the isolated compounds were evaluated by SwissADME online tool (http://www.swissadme.ch/). ADME (Absorption, Distribution, Metabolism and Excretion) properties depicts the compound acceptability in the body which is determined by Lipinski's rule of five [49].

\section{In Silico Toxicological Properties Prediction by AdmetSAR}

Toxicological characteristics of the isolated compounds were determined using the admetSAR online tool (http://Immd.ecust.edu.cn/admetsar1/predict/) since toxicity imparts a major concern during the development of new drugs. In the present study, ames toxicity, carcinogenic properties, acute oral toxicity, and rat acute toxicity were predicted [50].

\section{In Silico Prediction of Activity Spectra for Substances (PASS) Study by PASS Online}

The isolated compounds from EAF were examined for evaluating the anticancer, antiviral, free radical scavenging, lipid peroxidase inhibitor, and antioxidant activities by using PASS online (http://www.way2drug.com/PassOnline/) [51].

\section{Statistical Analysis}


All tests were carried out using the GraphPad Prism (version 8.4.3) and Microsoft Excel-2019 for the statistical and graphical evaluation. Data were presented as the mean \pm standard deviation (SD) from triplicate experiments. The data for significant differences between the tests and control groups was described using one-way analysis of variance (ANOVA). P-values of $<0.05,<0.01,<0.001$ and $<0.0001$ were considered statistically significant.

\section{Results}

\section{Determination of Antioxidant Compounds}

\section{Determination of Total Phenolic Content}

The content of total phenols of CME and its four fractions were determined using the FCR (Fig. 1A). The results showed that EAF contains the highest phenolic content $(267.05 \pm 8.53 \mathrm{mg} \mathrm{GAE} / \mathrm{gm}$ of dried sample). AQF (241.37 $\pm 17.38 \mathrm{mg}$ of GAE/gm of dried extract) and CME $(233.39 \pm 17.01 \mathrm{mg}$ of GAE/gm of dried extract) were also the rich sources of phenolic contents. On the other hand, CHF $(39.41 \pm 0.69 \mathrm{mg}$ of $\mathrm{GAE} / \mathrm{gm}$ of dried extract) and PEF (25.48 $\pm 0.3 \mathrm{mg}$ of GAE/gm of dried extract) were comparatively poor sources of phenolic content.

\section{Determination of Total Flavonoid Content}

The content of total flavonoids of CME with its four fractions, such as PEF, CHF, EAF and AQF were determined using well known aluminum chloride colorimetric method. Fig. 1B represents the total flavonoid content of all the extractives as $\mathrm{mg}$ of $\mathrm{CAE} / \mathrm{gm}$ of dried extract. The flavonoid content of $\mathrm{CME}$, PEF, CHF, EAF and AQF were found to be $131.41 \pm 1.58,60.96 \pm 0.7,82.31 \pm 3.15,152.98 \pm 1.96$ and $67.92 \pm 2.43 \mathrm{mg}$ of $\mathrm{CAE} / \mathrm{gm}$ of dried extractives, respectively. Comparing the total flavonoid content among the different fractions, it was noticed that EAF contained the highest amount of flavonoids followed by CME PEF, CHF and AQF.

\section{In vitro Antioxidant Assay}

\section{Total Antioxidant Activity}

The total antioxidant activity of the different extractives was assessed by phosphomolybdenum method based on the reduction of Mo (V1) to Mo (V). Total antioxidant activity of Me-LAL with its four fractions and standard (CA) was depicted in the Fig. 2A. Increased absorbance indicates increased antioxidants activity. EAF $(1 \pm 0.03$ absorbance at $100 \mu \mathrm{g} / \mathrm{mL})$ had the highest antioxidant activity among all the 
fractions and was closed to that of the standard $(1.06 \pm 0.09$ absorbance at $100 \mu \mathrm{g} / \mathrm{mL})$. CME $(0.89 \pm 0.05$ absorbance at $100 \mu \mathrm{g} / \mathrm{mL})$ and AQF $(0.79 \pm 0.01$ absorbance at $100 \mu \mathrm{g} / \mathrm{mL})$ also possessed better antioxidant activity than CHF $(0.23 \pm 0.02$ absorbance at $100 \mu \mathrm{g} / \mathrm{mL})$ and PEF $(0.31 \pm 0.05$ absorbance at $100 \mu \mathrm{g} / \mathrm{mL}$ ), but their antioxidant activity was slightly less than that of the standard and EAF. These results demonstrated that all the extractives of CME possessed noticeable antioxidant activity, which was concentration dependent.

\section{Ferric Reducing Power Capacity}

The reductive capabilities of the extractives and standard (AA) were shown in the Fig. 2B. It is well documented in several studies that higher the absorbance indicates higher reducing capacity and the increased absorbance follows concentration dependent manner [18]. The absorbance $(2.77 \pm 0.006)$ of EAF was closed to the absorbance (3.26 \pm 0.002$)$ of standard at a concentration of $50 \mu \mathrm{g} / \mathrm{mL}$ and EAF showed the highest reducing capacity among all the fractions. AQF (absorbance 1.78 \pm 0.19 ) and CHF (absorbance $0.83 \pm 0.09$ ) possessed moderate reducing activity compared to the standard at a concentration of $50 \mu \mathrm{g} / \mathrm{mL}$. These results demonstrated that CME and its fractions had significant iron reducing capacity, which was concentration dependent.

\section{DPPH Radical Scavenging Activity}

DPPH radical scavenging activity is based on the ability of the extractives to scavenge the stable DPPH radical that contains an odd electron. The results of DPPH radical scavenging assay of CME and its four fractions and standard (BHT) were given in the Fig. 3A and 3B. Among the fractions, EAF showed the highest and significant $(p=0.0001)$ free radical scavenging activity. The $\mathrm{IC}_{50}$ values of EAF, CME and AQF were found to be $6.92 \pm 0.19,6.09 \pm 0.13$ and $5.11 \pm 0.04 \mathrm{mg} / \mathrm{mL}$, respectively which were higher than the standard $\mathrm{BHT}\left(\mathrm{IC}_{50} 7.93 \pm 0.19 \mathrm{mg} / \mathrm{mL}\right)$. On the other hand, $\mathrm{CHF}$ and PEF showed moderate scavenging activity with $\mathrm{IC}_{50}$ values of $24.97 \pm 1.2 \mathrm{mg} / \mathrm{mL}$ and $9.52 \pm 0.17 \mathrm{mg} / \mathrm{mL}$, respectively. These observations demonstrated that all the extractives of CME possessed DPPH free radical scavenging activity.

\section{Hydroxyl Radical Scavenging Activity}

In the hydroxyl radical scavenging assay, the ability of the extractives of CME to remove the hydroxyl radical in solution was evaluated quantitatively by colorimetric method using CA as standard and \% of scavenging activity was calculated. The results of hydroxyl radical scavenging activity of different extractives and standard were shown in the Fig. $4 \mathrm{~A}$ and $4 \mathrm{~B}$. The $\mathrm{IC}_{50}$ values of CME, PEF, CHF, EAF, AQF and standard CA for hydroxyl radical scavenging activity were $121,475,325,37.5,165$ and $170 \mu \mathrm{g} / \mathrm{mL}$, respectively. Our results demonstrated that the EAF, AQF and CME showed higher activity when compared to the standard. Among the extracts, the EAF showed the significant $(p<0.0001)$ radical scavenging 
activity and the $\mathrm{IC}_{50}$ value of EAF was more than four times lower than that of the standard. Our results therefore clearly demonstrated that the fractionated extractives of CME possessed highly potent radical scavenging activity.

\section{In vitro Biological Studies of $L$. aequata}

\section{Lipid Peroxidation Inhibition Assay}

The results of lipid peroxidation inhibition of all the extractives of $C M E$ and standard CA were shown in the Fig. 5A and 5B. CME, PEF, CHF, EAF, AQF and CA showed 57.75 $\pm 0.43,51.5 \pm 0.39,53.54 \pm 0.15$, $62.83 \pm 0.58,59.11 \pm 0.72$ and $68.76 \pm 0.59$ percentage of lipid peroxidation inhibition, respectively at a concentration of $100 \mu \mathrm{g} / \mathrm{mL}$. Among the extractives, EAF $(p=0.0025)$ showed the highest inhibitory activity with $\mathrm{IC}_{50}$ value of $40 \mu \mathrm{g} / \mathrm{mL}$, which was closely similar to that of the CA (35 $\left.\mu \mathrm{g} / \mathrm{mL}\right)$. On the other hand, AQF had moderate inhibitory activity with $\mathrm{IC}_{50}$ value of $53 \mu \mathrm{g} / \mathrm{mL}$. The CHF and PEF showed comparatively less inhibitory activities. However, the inhibitory activity was concentration dependent.

\section{Cytotoxicity Assays}

In-vitro anticancer activity of all the extractives of CME and its four fractions and standard vincristin sulfate (VS) and 5-Fluorouracil (5-FU) on HeLa cell line was shown in the Fig. 6. The EAF showed the highest cytotoxic activity with $22.54 \%$ cell viability, whereas the standards VS and 5-FU showed $15.19 \%$ and $16.45 \%$ cell viability, respectively at a concentration of $500 \mu \mathrm{g} / \mathrm{mL}$. CME and CHF also showed moderate cytotoxicity with cell viability $27.74 \%$ and $32.01 \%$, respectively. However, the cytotoxic activity of EAF was in a concentration-dependent manner.

\section{Determination of HeLa cell apoptosis}

We evaluated the effect of EAF on HeLa cell apoptosis using DAPI, annexin-V FITC and PI triple fluorescence staining. Annexin V-FITC and PI signals were barely detectable in the control cells (without treatment), while treated cells exhibited strong fluorescence densities, indicating that EAF has capacity for inducing HeLa cell apoptosis (Fig. 7). Therefore, EAF was selected for GC-MS profiling to find out the compounds those might be responsible for apoptosis of HeLa cells.

\section{GC-MS Analysis}

GC-MS profiling was carried out on EAF because it was the most antioxidant rich and effective cytotoxic fraction among all the fractions. GC-MS profiling of EAF was shown in the Table 1 and it confirmed 17 different compounds (Fig. 8). The nature and the structure of the compounds were identified by the 
retention time. The compounds were of different chemical classes. Hexadecanoic acid, methyl ester (42.5\%), 9-Octadecenoic acid (Z)-, methyl ester (22.08\%), 9,12-Octadecadienoic acid, methyl ester (11.74\%), E-15-Heptadecenal (4.7\%), 1-Heneicosanol (4.28\%), E-14-Hexadecenal (3.22\%), Methyl stearate (2.56\%), Phenol, and 2,4-bis(1,1-dimethylethyl)- (2.21\%) were the major constituents of EAF. 1-

Tetradecene; 9-Hexadecenoic acid, methyl ester, (Z)-; Dodecanoic acid, methyl ester; Nonacos-1-ene; Tridecanoic acid, 12-methyl-, methyl ester; 11-Octadecenoic acid, methyl ester; Cyclopropane, nonyl- and n-Heptadecanol-1 were also present in the EAF.

\section{In silico Molecular Docking for Antioxidant Activity}

The outcomes for molecular-docking simulation for sixteen selective compounds were represented in the Table 2. In case of antioxidant property, the compounds were subjected against urate oxidase (PDB: 1R4U) and glutathione reductase (PDB: 3GRS). The orders for docking scores when bonded with urate

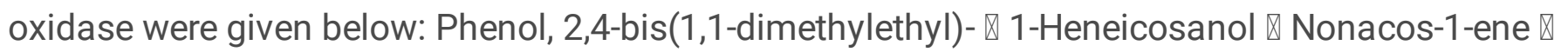

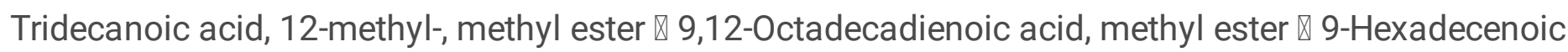
acid, methyl ester, (Z)- $₫ \mathrm{E}-14$-Hexadecenal $\nabla 11$-Octadecenoic acid, methyl ester $\nabla$ 9-Octadecenoic acid

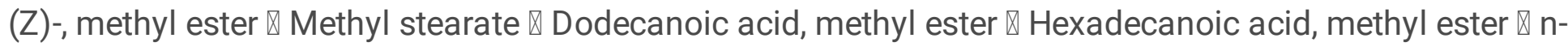
Heptadecanol-1 $₫$ Cyclopropane, nonyl- $\otimes 1$-Tetradecene. On the other hand, when interacted with glutathione reductase, the docking scores were in the following orders: Phenol, 2,4-bis(1,1-dimethylethyl)-

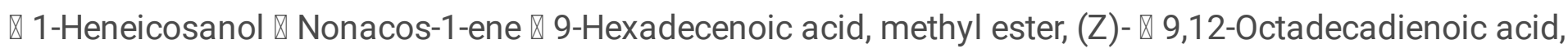



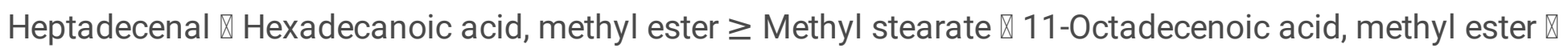


Tetradecene. The figures expressing the 3D conformation of ligand-receptor interactions for urate oxidase were given in the Fig. 9 and the interactions for glutathione reductase were given in the Fig. 10.

Furthermore, hydrogen and hydrophobic bonds between each compound and protein, which is associated with amino acid residues was expressed in the Table 3 and Table 4.

\section{In silico Molecular Docking for Anti-cancer Activity}

Two protein structures namely EGFR kinase domain (PDB: 2ITY) and caspase-3 (PDB: 5IAE) for HeLa cells were used in order to assess the anticancer activity of the selective compounds. When the compounds interacted with EGFR kinase domain, they showed docking scores in the following ordered:

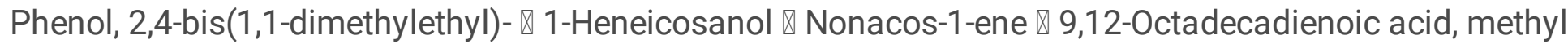

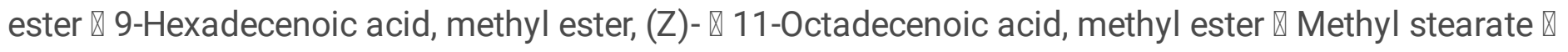

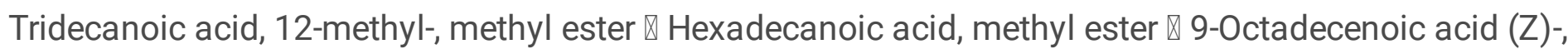
methyl ester $\otimes \mathrm{n}$-Heptadecanol-1 $\otimes \mathrm{E}-14$-Hexadecenal $\otimes$ Cyclopropane, nonyl- $\otimes$ Dodecanoic acid, methyl ester $\otimes \mathrm{E}-15$-Heptadecenal $\otimes 1-T e t r a d e c e n e . ~ O n$ the other hand, when the compounds interacted with caspase-3 the docking scores were in the following ordered: Phenol, 2,4-bis(1,1-dimethylethyl)- $\nabla 1$ - 
Heneicosanol $₫$ Nonacos-1-ene $\otimes$ 11-Octadecenoic acid, methyl ester $\otimes 9,12-$ Octadecadienoic acid, methyl ester $₫$ Tridecanoic acid, 12-methyl-, methyl ester $\otimes$ Methyl stearate $\otimes$ 9-Hexadecenoic acid, methyl ester, (Z)- $₫$ Dodecanoic acid, methyl ester $\otimes$ Hexadecanoic acid, methyl ester $\triangle$ 9-Octadecenoic acid (Z)-, methyl

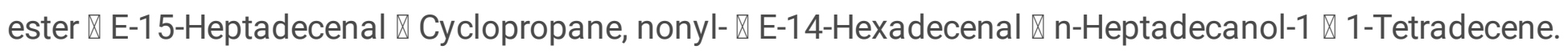
The 3D representations for ligand-receptor complex associated with EGFR kinase domain were given in the Fig. 11 and the representations regarding caspase-3 were given in the Fig. 12. Also, the bond corresponding to the interactions are given in Table 5 and Table 6.

\section{Determination of Pharmacokinetic Parameters by Swiss ADME and Toxicological Properties Prediction by AdmetSAR}

The ADME (Absorption, Distribution, Metabolism and Excretion) properties of the selected compounds were evaluated on the basis of Lipinski rule of five. The data regarding each of the parameters were retrieved from swissADME online server, which was given in the Table 7. Three of the compounds were violated more than one parameter of the standard basis. This evaluation suggested that all of the compound have drug-like property and favorable oral bio-availability except Hexadecanoic acid, methyl ester, 11-Octadecenoic acid, methyl ester and Nonacos-1-ene. Also, the toxicicological characteristics for each of the selective compounds were evaluated through AdmetSAR online server and have given in the Table 8. It depicted that all of the compounds were Non Ames Toxic and have little or insignificant rat acute toxicity which indicates that all of the compounds are safe for administration in the body.

\section{PASS Prediction Study by PASS Online}

Pass prediction study was carried out through PASS online server. All the compounds exhibited greater Pa value than $\mathrm{Pi}($ Table 9).

\section{Correlation and Regression of Phenolic and Flavonoid Content with Antioxidant and Cell Viability Potential}

Excellent positive association was seen through the correlation and regression study for phenolic and flavonoid content with radical scavenging activity and cell viability of the CME extractives. Table 10 and Table 11 represented the correlation and regression $(P<0.05, P<0.01, P<0.001$, and $P<0.0001)$ of phenolic and flavonoid content with the antioxidant and cell viability potential.

\section{Discussions}


Phenolic compound represents the largest group of phytochemicals and finds commonly in plants as free form or as glycosides. They show lots of biological activities, including anticancer, antimicrobial, antiulcer, antiarthritic, antiangiogenic, protein kinase inhibition and mitochondrial adhesion inhibition [7]. Flavonoids are the largest group of naturally occurring phenolic. They possess many biological activities, including antimicrobial, mitochondrial adhesion inhibition, antiulcer, antiarthritic, antiangiogenic, anticancer, protein kinase inhibition, etc. [52]. Phenolic and flavonoid compounds possess strong antioxidant property $[16,20]$. Plants containing large amounts of phenolic and flavonoid show strong antioxidant activity. In this study, CME extractives possessed a significant amount of phenolic and flavonoid. Interestingly, EAF and PEF contained the highest amount of phenolic and flavonoid, respectively. Based on these observations, we summarized that the extracts' radical-scavenging nature might depend on their polyphenolic content, i.e., phenolics and flavonoids. It is evident that total phenols and flavonoids are potential antioxidants and free radical scavengers [11, 18, 45]. Moreover, polyphenolic compounds have a wide spectrum of chemical and biological activity, including antioxidant and anticancer properties $[3,13]$. Free radicals produced in our body due to aerobic respiration and substrate oxidation, can cause oxidative stress which may contribute to the development of several diseases including cancer [3]. Overproduction of free radicals initiated oxidative stress in biological system. This oxidative stress causes serious damage to important cellular macromolecules such as protein and DNA. However, the production of free radicals can be balanced by antioxidant actions of endogenous enzymes as well as natural and synthetic antioxidants [3]. Antioxidants exert its action through several mechanisms including prevention of chain initiation, chelating of transition metal ion catalysts, decomposition of peroxidases, prevention of continued hydrogen abstraction and radical scavenging [15, 53].

The total antioxidant activity of different extractives of CME was determined by measuring their reduction power of $\mathrm{Mo}(\mathrm{VI})$ to $\mathrm{Mo}(\mathrm{V})$ and subsequent formation of a green phosphate/Mo $(\mathrm{V})$ complex. Dietary recommendations in recent years suggest increasing the consumption of foods containing polyphenolics, which have great impact on preventing chronic diseases, particularly cancer [54]. The evidence has brought the attention of scientists to an appreciation of antioxidants for prevention and treatment of diseases, and maintenance of human health [55]. In this study, the antioxidant capacity (in terms of absorbance at $700 \mathrm{~nm}$ ) of the extractives was in the range of $0.032 \pm 0.014-0.997 \pm 0.026$ at the concentration ranges from $6.25-100 \mu \mathrm{g} / \mathrm{mL}$. Recent studies have shown that many flavonoid and related polyphenols contribute significantly to the phosphomolybdate scavenging activity of medicinal plants [3]. All the extracts showed good antioxidant activities that were gradually increased with increasing concentration. Interestingly, EAF contained the highest antioxidant activity, which was similar to the standard (CA). The highest antioxidant activity of EAF was due to the presence of polyphenolics. Previously, many researchers have proven that the antioxidant capacity of citrus was due to the presence of phenolics, flavonoids, and ascorbic acid [56]. Abdurahman $\mathrm{NH}$ et al. reported that phenolic compounds, $\beta$-Glucogallin and apocynin showed antioxidant activity in Vernonia cinereal leaves [57].

The ferric reducing power capacity is considered as another prominent indicator of anti-radical activity [58]. The mechanism of FRA capacity is associated with the presence of a reductant that donates a 
hydrogen atom after ROS breakdown. In the current study, EAF showed the highest ferric reducing power capacity through its reduction of the $\mathrm{Fe}^{3+}$-ferricyanide complex into the ferrous form, which was monitored through the blue-green complex at $700 \mathrm{~nm}$. The ferric reducing power capacity of the CME and all the extractives ware in the range of $0.073 \pm 0.015-3.264 \pm 0.01$ at the concentration ranges from $6.25-100 \mu \mathrm{g} / \mathrm{mL}$ shown in the Fig. $2 \mathrm{~B}$. This finding denoted that the reducing power of all extractives was dose dependent which supports the finding of the previous studies $[7,53,59]$. The significant reducing power of EAF $(p<0.05)$ was possibly due to the presence of phenolic constituents, which might act as electron donors. The absorbance $(2.77 \pm 0.006)$ of EAF was close to the absorbance $(3.26 \pm 0)$ of standard, AA at a concentration of $50 \mu \mathrm{g} / \mathrm{mL}$. This result indicates that LAL contains a higher number of potent antioxidants which could stabilize and block free radical chain reactions.

DPPH radical scavenging activity is the most common method used for determining antioxidant activity. The antioxidant activity depends on the donating hydrogen or electron to stabilize the purple coloured DPPH free radical into reduced form of DPPH which is pale yellow colour [53]. A stable diamagnetic molecule is formed by the DPPH radical by accepting an electron or hydrogen radical, which is followed by the solution changing color from blue to yellow. This color-changing technique is a widely accepted in vitro method because of its simplicity, stability, and reproducibility [60]. All CME fractions showed significant DPPH scavenging activity $(p<0.01)$. The order of the $\mathrm{IC}_{50}$ of $\mathrm{CME}, \mathrm{PEF}, \mathrm{CHF}, \mathrm{EAF}, \mathrm{AQF}$, and the standard BHT was as follows: $\mathrm{EAF}>\mathrm{CME}>\mathrm{AQF}>\mathrm{BHT}>\mathrm{CHF}>\mathrm{PEF}$. EAF had a significant $\mathrm{IC}_{50}$ value $(p<$ 0.01) that was almost identical to that of BHT. Duan et al. (20007) reported that phenolics and flavonoids can reduce DPPH radicals by donating hydrogen ions [61]. Our results are consistent with that of the data published previously $[3,13,62]$.

Hydroxyl radicals are the most highly ROS causing noxious effects on protein, lipids and nucleic acids. This can cause damage to cellular components by reacting with the polyunsaturated fatty acid of cell membrane phospholipids [18]. The hydroxyl radicals attack the fatty acid side chains of the membrane phospholipids and add a double bond to DNA bases [63]. The modification of the DNA bases may initiate different cellular process malfunctions, which are characterized by the primary pace of carcinogenesis [64]. In addition, the hydroxyl radicals are generated in the biological system by Fenton reaction with subsequent degradation of deoxyribose to TBARS which generates a pink chromogen on heating at low $\mathrm{pH}$ with thiobarbituric acid (TBA) [65]. In our investigation, CME and its extractives showed promising hydroxyl radical scavenging activity and were capable of protecting deoxyribose in a dose dependent manner. There is evidence that the hydroxyl radical activity of the extract is directly proportioned to its antioxidant activity [66]. Our results demonstrated that EAF, AQF and CME possessed higher hydroxyl radical scavenging activity than that of the $\mathrm{CA}$ (standard). The $\mathrm{IC}_{50}$ value of the most potent radical scavenger, EAF was four times lower than that of the standard CA. So, EAF can serve a potent hydroxyl radical scavenger and may protect cell and cellular components. Previous research finding showed that extracts which are able to scavenge hydroxyl radical can have ability to inhibit lipid peroxidation and break free radical chain reaction [62]. 
Lipid peroxides are highly reactive and more stable than ROS. They can diffuse from where they generate and show detrimental effects to the remote location as well as the site of generation. High concentration of lipid peroxide in the body is responsible for many life threatening diseases, including cancer. Therefore, limiting the formation of lipid peroxide generation is beneficial for controlling the life threatening diseases [7]. Antioxidant potential of extract or fraction is directly related to the scavenging of hydroxyl radical and consequently the inhibition of lipid peroxidation [67]. The erythrocytes intrinsically are more prone to peroxidation due to the heavy accumulation of polyunsaturated fatty acids and haemoglobin. During respiration erythrocytes are continuously exposed to high tension of oxygen, which can induce oxidative damage [68]. Our finding showed that the EAF showed the highest inhibitory activity with $\mathrm{IC}_{50}$ value $(40.00 \mu \mathrm{g} / \mathrm{mL})$ among all the extractives which was close to that of CA $(35.00 \mu \mathrm{g} / \mathrm{mL})$. CHF and AQF also had moderate inhibitory activity with the $\mathrm{IC}_{50}$ value of 82 and $53 \mu \mathrm{g} / \mathrm{mL}$, respectively, was comparable to the standard, CA. The extract's ability to inhibit lipid peroxidation could be attributed to the presence of lipid-soluble antioxidant compounds, hence, could donate protons to stabilize lipid radicals or exquisitely scavenges lipid peroxyl radicals, thereby, terminating subsequent chain propagation reactions [69]. Current evidence suggests that, $L$. aequata has antioxidant potential and the capacity to combat ROS associated damage because of its reducing power capacity as well as radical-scavenging activity.

Cancer is developed by cellular damage. Free radicals are responsible for cellular damage. The main characteristic of cancer cells is uncontrolled rapid proliferation. These cells are less prone to death [10]. Many naturally occurring compounds such as alkaloids, phenolics, flavonoids and saponins exhibit anticancer activity by inhibiting cell proliferation and angiogenesis, causing cell cycle arrest, and/or inducing cell apoptosis $[10,70]$. Cancer can be stimulated by chromosomal irregularities and oncogene initiation determined by oxidative stress [71]. A byproduct termed hydrolyzed DNA is formed by DNA oxidation [72], and this byproduct initiates transcriptomic changes, and genes are mutated. Furthermore, reactive oxygen species are responsible for modifying DNA-protein cross-links, base and sugar lesions, strand breaks, and base-free sites [2]. Antioxidants are a class of compounds that mop up reactive oxygen species and prevent cancer. Our finding showed that EAF possessed more profound cytotoxic activity which is very close to that of standard VS and 5-FU on HeLa cell line. This cytotoxic activity may be due to the presence of high number of flavonoids, saponins and other compounds. The dose dependent activity showed that the presence of a high concentration of compounds exhibited less percentage of HeLa cancer cell viability.

Furthermore, the effect of EAF on HeLa cell apoptosis was evaluated using DAPI, annexin V-FITC and PI triple florescence staining. DAPI is used as a marker of cell membrane permeability seen in very late apoptotic cells; whereas, annexin V-FITC staining can identify apoptosis at an earlier stage [6]. In the present study, DAPI, annexin V-FITC, and PI signals were barely detectable in the control cells (without treatment), while treated cells had strong fluorescence densities, indicating that the EAF has the capacity for inducing HeLa cell apoptosis through the early and late stages (Fig. 7).

EAF is the most antioxidative and cytotoxic fraction among all the fractions of CME. GC-MS data of EAF explored the chemical constituents and its proportion in EAF. Hexadecanoic acid, methyl ester was 
present as $42.5 \%$ of EAF which was reported as antioxidant and for cancer prevention [29]. 9Octadecenoic acid (Z)-, methyl ester which is the second major constituent (22.08\%) of EAF, has been reported for the prevention of cancer, antioxidant and anticancer activity [49]. 9,12-octadecadienoic acid, methyl ester $(Z, Z)$ have been showed to be powerful anticancer activity with an $\mathrm{IC}_{50}$ value of $10.60 \pm 1.12$ against human lung cancer cell line A549. It has been previously proven that unsaturated fatty acid ester possessed significant antioxidant properties [73]. It has also been reported that fatty acid esters are deposited on the lipid layer of cell membrane and mitochondria. Thus, they showed cytotoxicity by increasing the permeability of cells due to the lack of integrity of cellular structure. Phenol, 2,4-bis(1,1dimethylethyl)- was reported for antioxidant and antitumor activity [7].

Molecular docking is an integral segment in the structural molecular biology discipline which is designed to evaluate the probable ligand-protein synergy through computational approach [74]. Besides, it helps revealing the mechanism of action of the investigational compounds extrapolated from various natural sources and provides an efficient way to discovery of new active medicinal agent in order to serves a remedy for various diseases [75]. In this study, molecular docking simulation was performed to associate and reciprocate the findings with the current in vitro study. Sixteen compounds from $L$. aequata were selected in order to carry out molecular docking simulation for antioxidant and anticancer activity. Two protein namely urate oxidase (PDB: 1R4U) and glutathione reductase (PDB: $3 G R S$ ) were selected as ligand target for antioxidant activity. When compounds were subjected to docking simulation against urate oxidase, Phenol, 2,4-bis(1,1-dimethylethyl)- possessed the highest score (-4.196). Moreover, when the compounds were in complex with glutathione reductase, the same compound found to have the best outcome (-5.262). Phenol, 2,4-bis(1,1-dimethylethyl)- when interacted with urate oxidase it was formed two pi-alkyl bond with ARG-176 and HIS-256 and a conventional hydrogen bond with LYS-171. Again, when this compound interacted with glutathione reductase it has formed only a conventional hydrogen bond with THR-156. The docking score for this compound when compared to the standard drug ascorbic acid, it was seen that the result was very close. Which suggested that the compound to be a potential antioxidant agent. On the other hand, EGFR kinase domain (PDB: 2ITY) and caspase 3 (PDB: 5IAE) were used as a receptor for the experimental compound to determine their anticancer activity. After docking simulation, phenol, 2,4-bis(1,1-dimethylethyl)-found to have the best docking score (-5.512) when interacted with EGFR kinase domain and in case of caspase 3, the same compound were found to have the best result (-5.631). After comparing with the standard drug 5-fluorouracil, the compound possessed better score than the standard for both proteins. Phenol, 2,4-bis(1,1-dimethylethyl)- has formed a conventional hydrogen bond with ASP-855 and an alkyl bond LEU-718. Also, two pi-alkyl bond with LEU844 and VAL-726 when it was in interaction with active site of EGFR kinase domain. This compound when interacted with caspase 3 receptors, it was formed one conventional hydrogen bond with ARG-207, a pi-pi stacked bond with TRP-206 and a pi-alkyl bond with TYR-204. Moreover, other compounds also shown good affinity with each of these four distinctive proteins for anticancer and antioxidant activity. Furthermore, each of these experimental compounds was evaluated for ADME and toxicological analysis. According to Lipinski rule of five orally administered agents should satisfy the following criteria: Molecular weight $\leq 500$, Hydrogen bond donor $\leq 5$, Hydrogen bond acceptor $\leq 10$, LogP $\leq 5$, Molar 
refractivity 40-130 [49]. This rule depicted that one compound or possible medicinal agent cannot breach all of the parameter in order to have good oral bioavailability $[50,76,77]$. ADME analysis on the basis of Lipinski rule of five revealed that all of the compounds satisfied the given criteria except Hexadecanoic acid, methyl ester, 11-Octadecenoic acid, methyl ester and Nonacos-1-ene. Furthermore, toxicity evaluation of the selective compounds demonestrated that all of the compounds were Non AMES toxic and possess insignificant level of toxic property. Total phenolic and flavonoid contents of the $L$. aequata showed significant and strong positive correlation ( $p$-value $<0.001$ and 0.05 ) with antioxidants (DPPH) and cell viability assay. Our results are consistent with those found by Islam et al., [3] who reported that there is existence of a strong relationship between total phenolic contents and DPPH radical scavenging. Henceforth, it is evident from the molecular docking analysis that the isolated compounds from $L$. aequata possessed significant antioxidant and anticancer property and can be a potential source of probable medicinal agent to treat cancer and reactive oxygen species related complications.

\section{Conclusion}

The present study indicates that EAF fraction of $L$. aequata was the potential source of polyphenols, which showed significant antioxidant and cytotoxic activities. EAF also induced HeLa cell apoptosis. GCMS data revealed that EAF contained different important phytoconstituents. Our study suggests that many bioactive compounds of EAF can be used to develop the beneficial drugs to manage various diseases like cancer.

\section{Declarations}

\section{Ethics declarations}

The Animal Ethical Committee, Rajshahi University (27/08/RUBCMB) and the Committee of Cell Research of Rajshahi Medical College, Bangladesh (ref. RMC/ER/2010-2013/01) approved the current research.

\section{Consent for publication}

Not applicable.

\section{Availability of data and materials}

All data related to this research are available within the manuscript.

\section{Conflict of Interests}

The author(s) declare(s) that there is no conflict of interests regarding the publication of this article. 


\section{Funding:}

The authors declare that they have no fund for this research.

\section{Contributions}

Md. Golam Mostofa, A.S.M. Ali Reza, Zidan Khan, Toshifumi Tsukahara, AHM Khurshid Alam

Investigation, Software and Methodology: Md. Golam Mostofa, A.S.M. Ali Reza, AHM Khurshid Alam Conceptualization, Investigation and Supervision: AHM Khurshid Alam, Toshifumi Tsukahara

Funding acquisition and Validation: AHM Khurshid Alam

Formal Analysis, Methodology: AHM Khurshid Alam, Md. Golam Mostofa and A.S.M. Ali Reza

Writing-original draft: Md. Golam Mostofa, AHM Khurshid Alam, A.S.M. Ali Reza

Writing-review \& editing: AHM Khurshid Alam, A.S.M. Ali Reza

Resources, Software: AHM Khurshid Alam, Zidan Khan

Project administration and Supervision: AHM Khurshid Alam

\section{Acknowledgement}

The authors wish to thank the Department of Pharmacy, University of Rajshahi for their kind support in progress of the research. The authors also want to give thank JASSO for providing follow-up research grant at JAIST, Japan.

\section{References}

1. Moni JNR, Adnan M, Tareq AM, Kabir M, Reza A, Nasrin M, Chowdhury KH, Sayem SAJ, Rahman MA, Alam A: Therapeutic Potentials of Syzygium Fruticosum Fruit (Seed) Reflect Into An Array of Pharmacological Assays and Prospective Receptors-Mediated Pathways. Life 2021, 11(2):155.

2. Pizzino G, Irrera N, Cucinotta M, Pallio G, Mannino F, Arcoraci V, Squadrito F, Altavilla D, Bitto A: Oxidative stress: harms and benefits for human health. Oxidative Medicine and Cellular Longevity 2017, 2017.

3. Islam S, Nasrin S, Khan MA, Hossain AS, Islam F, Khandokhar P, Mollah MNH, Rashid M, Sadik G, Rahman MAA: Evaluation of antioxidant and anticancer properties of the seed extracts of Syzygium fruticosum Roxb. growing in Rajshahi, Bangladesh. BMC complementary and alternative medicine 2013, 13(1):142. 
4. Marcadenti A, Assis Coelho R: Dietary antioxidant and oxidative stress: interaction between vitamins and genetics. J Nutrition Health Food Sci 2015, 3(1):1-7.

5. Raychaudhuri S, Mandal S: Current status of knowledge, attitude and practice (KAP) and screening for cervical cancer in countries at different levels of development. Asian Pacific Journal of Cancer Prevention 2012, 13(9):4221-4227.

6. Reza AA, Haque MA, Sarker J, Nasrin MS, Rahman MM, Tareq AM, Khan Z, Rashid M, Sadik MG, Tsukahara T: Antiproliferative and antioxidant potentials of bioactive edible vegetable fraction of Achyranthes ferruginea Roxb. in cancer cell line. Food Science \& Nutrition.

7. Rahman MM, Hossain AS, Mostofa MG, Khan MA, Ali R, Mosaddik A, Sadik MG, Alam AK: Evaluation of anti-ROS and anticancer properties of Tabebuia pallida L. Leaves. Clinical Phytoscience 2019, $5(1): 1-12$.

8. Lichota A, Gwozdzinski K: Anticancer activity of natural compounds from plant and marine environment. International journal of molecular sciences 2018, 19(11):3533.

9. Florento L, Matias R, Tuaño E, Santiago K, dela Cruz F, Tuazon A: Comparison of cytotoxic activity of anticancer drugs against various human tumor cell lines using in vitro cell-based approach. International journal of biomedical science: IJBS 2012, 8(1):76.

10. Rahman MM, Reza AMA, Khan MA, Sujon KM, Sharmin R, Rashid M, Sadik MG, Reza MA, Tsukahara T, Capasso R: Unfolding the Apoptotic Mechanism of Antioxidant Enriched-Leaves of Tabebuia pallida (Lindl.) Miers in EAC Cells and Mouse Model. Journal of Ethnopharmacology 2021:114297.

11. Islam MR, Reza A, Chawdhury KAA, Uddin J, Farhana K: Evaluation of in vitro antioxidant activity and cytotoxicity of methanolic extract of Sida cordata leaves. Int J Biol Pharm Res 2014, 5(2):196-200.

12. Prasad S, Gupta SC, Tyagi AK: Reactive oxygen species (ROS) and cancer: Role of antioxidative nutraceuticals. Cancer letters 2017, 387:95-105.

13. Reza AA, Nasrin MS, Alam AK: Phytochemicals, Antioxidants, and Cholinesterase Inhibitory Profiles of Elatostema Papillosum Leaves: An Alternative Approach for Management of Alzheimer's Disease. 2018.

14. Tan BL, Norhaizan ME, Liew W-P-P, Sulaiman Rahman H: Antioxidant and oxidative stress: a mutual interplay in age-related diseases. Frontiers in pharmacology 2018, 9:1162.

15. Hossen MA, Reza AA, Ahmed AA, Islam MK, Jahan I, Hossain R, Khan MF, Maruf MRA, Haque MA, Rahman MA: Pretreatment of Blumea lacera leaves ameliorate acute ulcer and oxidative stress in ethanol-induced Long-Evan rat: A combined experimental and chemico-biological interaction. Biomedicine \& Pharmacotherapy 2021, 135:111211.

16. Islam MN, Tasnim H, Arshad L, Haque MA, Tareq SM, Kamal AM, Rahman MM, Reza ASA, Chowdhury KAA, Tareq AM: Stem extract of Albizia richardiana exhibits potent antioxidant, cytotoxic, antimicrobial, anti-inflammatory and thrombolytic effects through in vitro approach. Clinical Phytoscience 2020, 6(1):1-9.

17. Chow A: Cell Cycle Control by Oncogenes and Tumor Suppressors: Driving the. 2010. 
18. Reza AA, Hossain MS, Akhter S, Rahman MR, Nasrin MS, Uddin MJ, Sadik G, Alam AK: In vitro antioxidant and cholinesterase inhibitory activities of Elatostema papillosum leaves and correlation with their phytochemical profiles: a study relevant to the treatment of Alzheimer's disease. $B M C$ complementary and alternative medicine 2018, 18(1):123.

19. Hossain KH, Rahman MA, Taher M, Tangpong J, Hajjar D, Alelwani W, Makki AA, Reza AA: Hot Methanol Extract of Leea Macrophylla (Roxb.) manages chemical-induced inflammation in Rodent Model. Journal of King Saud University-Science 2020.

20. Tareq AM, Farhad S, Uddin AN, Hoque M, Nasrin MS, Uddin MMR, Hasan M, Sultana A, Munira MS, Lyzu C: Chemical profiles, pharmacological properties, and in silico studies provide new insights on Cycas pectinata. Heliyon 2020, 6(6):e04061.

21. Amaral R, dos Santos SA, Andrade LN, Severino P, Carvalho AA: Natural products as treatment against cancer: a historical and current vision. Clin. Oncol 2019, 4(5):1562.

22. Jackson SJ, Murphy LL, Venema RC, Singletary KW, Young AJ: Curcumin binds tubulin, induces mitotic catastrophe, and impedes normal endothelial cell proliferation. Food and chemical toxicology 2013, 60:431-438.

23. Malik S, Cusidó RM, Mirjalili MH, Moyano E, Palazón J, Bonfill M: Production of the anticancer drug taxol in Taxus baccata suspension cultures: a review. Process Biochemistry 2011, 46(1):23-34.

24. Son IH, Chung I-M, Lee SI, Yang HD, Moon H-I: Pomiferin, histone deacetylase inhibitor isolated from the fruits of Maclura pomifera. Bioorganic \& medicinal chemistry letters 2007, 17(17):4753-4755.

25. Gali-Muhtasib H, Roessner A, Schneider-Stock R: Thymoquinone: a promising anti-cancer drug from natural sources. The international journal of biochemistry \& cell biology 2006, 38(8):1249-1253.

26. SUWARSO E, GINTING N, SUDARMI VD: IN VITRO ANTICONVULSANT EFFECT OF ETHYL ACETATE FRACTION OF TITANUS LEAF (LEEA AEQUATA L.) ON ISOLATED COLON. 2018.

27. Tun NL, Hu D-B, Xia M-Y, Zhang D-D, Yang J, Oo TN, Wang Y-H, Yang X-F: Chemical constituents from ethanoic extracts of the aerial parts of Leea aequata L., a traditional folk medicine of Myanmar. Natural products and bioprospecting 2019, 9(3):243-249.

28. Halder S, Saqueeb N, Qais N: Antinociceptive and anthelmintic activities of leaves of Leea aequata. Dhaka University Journal of Pharmaceutical Sciences 2018, 17(2):251-255.

29. Rahim A, Mostofa MG, Sadik MG, Rahman MAA, Khalil MI, Tsukahara T, Nakagawa-Goto K, Alam AK: The anticancer activity of two glycosides from the leaves of Leea aequata L. Natural Product Research 2020:1-5.

30. Khare CP: Indian herbal remedies: rational Western therapy, ayurvedic, and other traditional usage, Botany: Springer science \& business media; 2004.

31. Suwarso E, Ginting N, Sudarmi S, Manurung V: In vitro anticonvulsant effect of ethyl acetate fraction of titanus leaf (Leea aequata L.) on isolated colon. Asian J. Pharmaceut. Clin. Res 2018, 11(1):248251.

32. Wolfe K, Wu X, Liu RH: Antioxidant activity of apple peels. Journal of agricultural and food chemistry 2003, 51(3):609-614. 
33. Prieto P, Pineda M, Aguilar M: Spectrophotometric quantitation of antioxidant capacity through the formation of a phosphomolybdenum complex: specific application to the determination of vitamin $\mathrm{E}$. Analytical biochemistry 1999, 269(2):337-341.

34. Oyaizu M: Studies on products of browning reaction. Antioxidant activities of products of browning reaction prepared from glucoamine. Jap. J. Nutri, 986(44):307-315.

35. Blois MS: Antioxidant determinations by the use of a stable free radical. nature 1958, 181(4617):1199-1200.

36. Desmarchelier C, Novoa Bermudez M, Coussio J, Ciccia G, Boveris A: Antioxidant and prooxidant activities in aqueous extracts of Argentine plants. International journal of pharmacognosy 1997, 35(2):116-120.

37. Halliwell B: Lipid peroxidation: a radical chain reaction. Free radicals in biology and medicine 1989.

38. Luo Z, Valeru A, Penjarla S, Liu B, Khan I: Synthesis, anticancer activity and molecular docking studies of novel pyrido[1,2-a]pyrimidin-4-one derivatives. Synthetic Communications 2019, 49(17):2235-2243.

39. Maciag JJ, Mackenzie SH, Tucker MB, Schipper JL, Swartz P, Clark AC: Tunable allosteric library of caspase 3 identifies coupling between conserved water molecules and conformational selection. Proc Natl Acad Sci U S A 2016, 113(41):E6080-e6088.

40. Zhao G-F, Huang Z-A, Du X-K, Yang M-L, Huang D-D, Zhang S: Molecular docking studies of Traditional Chinese Medicinal compounds against known protein targets to treat non-small cell lung carcinomas. Mol Med Rep 2016, 14(2):1132-1138.

41. Karplus PA, Schulz GE: Refined structure of glutathione reductase at 1.54 A resolution. J Mol Biol 1987, 195(3):701-729.

42. Retailleau P, Colloc'h N, Vivares D, Bonnete F, Castro B, El-Hajji M, Mornon JP, Monard G, Prange T: Complexed and ligand-free high-resolution structures of urate oxidase (Uox) from Aspergillus flavus: a reassignment of the active-site binding mode. Acta crystallographica. Section D, Biological crystallography 2004, 60(Pt 3):453-462.

43. Berman HM, Battistuz T, Bhat T, Bluhm WF, Bourne PE, Burkhardt K, Feng Z, Gilliland GL, lype L, Jain S: The protein data bank. Acta Crystallogr. Sect. D. Biol. Crystallogr. 2002, 58(6):899-907.

44. Uddin M, Ali Reza A, Abdullah-Al-Mamun M, Kabir MS, Nasrin M, Akhter S, Arman M, Islam S, Rahman M: Antinociceptive and Anxiolytic and Sedative Effects of Methanol Extract of Anisomeles indica: An Experimental Assessment in Mice and Computer Aided Models. Frontiers in pharmacology 2018, 9:246.

45. Adnan M, Chy M, Uddin N, Kamal A, Chowdhury KAA, Rahman M, Reza A, Moniruzzaman M, Rony SR, Nasrin M: Intervention in Neuropsychiatric Disorders by Suppressing Inflammatory and Oxidative Stress Signal and Exploration of In Silico Studies for Potential Lead Compounds from Holigarna caustica (Dennst.) Oken leaves. Biomolecules 2020, 10(4):561.

46. Harder E, Damm W, Maple J, Wu C, Reboul M, Xiang JY, Wang L, Lupyan D, Dahlgren MK, Knight JL: OPLS3: a force field providing broad coverage of drug-like small molecules and proteins. Journal of 
chemical theory and computation 2016, 12(1):281-296.

47. Friesner RA, Banks JL, Murphy RB, Halgren TA, Klicic JJ, Mainz DT, Repasky MP, Knoll EH, Shelley M, Perry JK: Glide: a new approach for rapid, accurate docking and scoring. 1. Method and assessment of docking accuracy. J. Med. Chem. 2004, 47(7):1739-1749.

48. Friesner RA, Murphy RB, Repasky MP, Frye LL, Greenwood JR, Halgren TA, Sanschagrin PC, Mainz DT: Extra precision glide: Docking and scoring incorporating a model of hydrophobic enclosure for protein - ligand complexes. J. Med. Chem. 2006, 49(21):6177-6196.

49. Lipinski CA: Lead-and drug-like compounds: the rule-of-five revolution. Drug Discovery Today: Technologies 2004, 1(4):337-341.

50. Veber DF, Johnson SR, Cheng H-Y, Smith BR, Ward KW, Kopple KD: Molecular properties that influence the oral bioavailability of drug candidates. Journal of medicinal chemistry 2002, 45(12):2615-2623.

51. Filimonov D, Lagunin A, Gloriozova T, Rudik A, Druzhilovskii D, Pogodin P, Poroikov V: Prediction of the biological activity spectra of organic compounds using the PASS online web resource. Chemistry of Heterocyclic Compounds 2014, 50(3):444-457.

52. Sulaiman C, Balachandran I: Total phenolics and total flavonoids in selected Indian medicinal plants. Indian journal of pharmaceutical sciences 2012, 74(3):258.

53. Hossain MS, Reza AA, Rahaman MM, Nasrin MS, Rahat MRU, Islam MR, Uddin MJ, Rahman MA: Evaluation of morning glory (Jacquemontia tamnifolia (L.) Griseb) leaves for antioxidant, antinociceptive, anticoagulant and cytotoxic activities. Journal of basic and clinical physiology and pharmacology 2018, 29(3):291-299.

54. Zhang Y-J, Gan R-Y, Li S, Zhou Y, Li A-N, Xu D-P, Li H-B: Antioxidant phytochemicals for the prevention and treatment of chronic diseases. Molecules 2015, 20(12):21138-21156.

55. Mobarak H, Meah MS, Sikder N, Tareq M, Azad A, Khatun R, Nasrin MS, Raihan MO, Reza AA: Investigation of Preliminary Phytochemicals, Analgesic, Anti-Arthritic, Thrombolytic and Cytotoxic Activities of Begonia Roxburghii (Miq.) DC. Leaves. 2018.

56. Jayaprakasha G, Girennavar B, Patil BS: Radical scavenging activities of Rio Red grapefruits and Sour orange fruit extracts in different in vitro model systems. Bioresource technology 2008, 99(10):4484-4494.

57. Alara OR, Abdurahman NH, Ukaegbu $\mathrm{Cl}$, Azhari $\mathrm{NH}$ : Vernonia cinerea leaves as the source of phenolic compounds, antioxidants, and anti-diabetic activity using microwave-assisted extraction technique. Industrial Crops and Products 2018, 122:533-544.

58. Oliveira I, Sousa A, Ferreira IC, Bento A, Estevinho L, Pereira JA: Total phenols, antioxidant potential and antimicrobial activity of walnut (Juglans regia L.) green husks. Food Chem. Toxicol. 2008, 46(7):2326-2331.

59. Bristy TA, Barua N, Montakim Tareq A, Sakib SA, Etu ST, Chowdhury KH, Jyoti MA, Aziz M, Ibn A, Reza A: Deciphering the Pharmacological Properties of Methanol Extract of Psychotria calocarpa Leaves by In Vivo, In Vitro and In Silico Approaches. Pharmaceuticals 2020, 13(8):183. 
60. Reddy BS, Reddy RKK, Reddy BP, Ramakrishna S, Diwan PV: Potential in vitro antioxidant and protective effects of Soymida febrifuga on ethanol induced oxidative damage in HepG2 cells. Food and chemical toxicology 2008, 46(11):3429-3442.

61. Duan X, Wu G, Jiang Y: Evaluation of the antioxidant properties of litchi fruit phenolics in relation to pericarp browning prevention. Molecules 2007, 12(4):759-771.

62. Khan MA, Rahman AA, Islam S, Khandokhar P, Parvin S, Islam MB, Hossain M, Rashid M, Sadik G, Nasrin S: A comparative study on the antioxidant activity of methanolic extracts from different parts of Morus alba L.(Moraceae). BMC Research Notes 2013, 6(1):24.

63. Halliwell B: Reactive oxygen species in living systems: source, biochemistry, and role in human disease. The American journal of medicine 1991, 91(3):S14-S22.

64. Pandey A, Mishra A, Mishra A: Antifungal and antioxidative potential of oil and extracts derived from leaves of Indian spice plant Cinnamomum tamala. Cellular and Molecular Biology 2012, 58(1):142147.

65. Halliwell B, Gutteridge JM, Aruoma OI: The deoxyribose method: a simple "test-tube" assay for determination of rate constants for reactions of hydroxyl radicals. Anal. Biochem. 1987, 165(1):215219.

66. Gülçin İ, Berashvili D, Gepdiremen A: Antiradical and antioxidant activity of total anthocyanins from Perilla pankinensis decne. J. Ethnopharmacol. 2005, 101(1):287-293.

67. Orabi KY, Al-Qasoumi SI, El-Olemy MM, Mossa JS, Muhammad I: Dihydroagarofuran alkaloid and triterpenes from Maytenus heterophylla and Maytenus arbutifolia. Phytochemistry 2001, 58(3):475480.

68. Babu B, Shylesh B, Padikkala J: Antioxidant and hepatoprotective effect of Acanthus ilicifolius. Fitoterapia 2001, 72(3):272-277.

69. Wang X, Quinn PJ: Vitamin E and its function in membranes. Progress in lipid research 1999, 38(4):309-336.

70. Haque MA, Reza AA, Nasrin MS, Rahman MA: Pleurotus highking mushrooms potentiate antiproliferative and antimigratory activity against triple-negative breast cancer cells by suppressing Akt signaling. Integrative cancer therapies 2020, 19:1534735420969809.

71. Reuter S, Gupta SC, Chaturvedi MM, Aggarwal BB: Oxidative stress, inflammation, and cancer: how are they linked? Free radical biology and medicine 2010, 49(11):1603-1616.

72. Valko M, Izakovic M, Mazur M, Rhodes CJ, Telser J: Role of oxygen radicals in DNA damage and cancer incidence. Molecular and cellular biochemistry 2004, 266(1-2):37-56.

73. Erwin E, Pusparohmana WR, Sari IP, Hairani R, Usman U: Phytochemical and antioxidant activity evaluation of the bark of Tampoi (Baccaurea macrocarpa). F1000Research 2018, 7.

74. Khan S, Nazir M, Raiz N, Saleem M, Zengin G, Fazal G, Saleem H, Mukhtar M, Tousif MI, Tareen RB: Phytochemical profiling, in vitro biological properties and in silico studies on Caragana ambigua stocks (Fabaceae): A comprehensive approach. Industrial Crops and Products 2019, 131:117-124. 
75. Morris GM, Lim-Wilby M: Molecular docking. In: Molecular modeling of proteins. edn.: Springer; 2008 : 365-382.

76. Lipinski CA, Lombardo F, Dominy BW, Feeney PJ: Experimental and computational approaches to estimate solubility and permeability in drug discovery and development settings. Advanced drug delivery reviews 1997, 23(1-3):3-25.

77. Duffy FJ, Devocelle M, Shields DC: Computational approaches to developing short cyclic peptide modulators of protein-protein interactions. In: Computational Peptidology. edn.: Springer; 2015: 241-271.

\section{Tables}

\section{Board 1}

GC-MS profiling of EAF of $L$. aequata leaves.

\begin{tabular}{|lllll|}
\hline Name & R. Time & $\mathrm{m} / \mathrm{z}$ & Area & Concentration (\%) \\
\hline Cyclopropane, nonyl- & 8.103 & 55 & 9221 & $0.22 \%$ \\
\hline 1-Tetradecene & 13.337 & 55 & 57746 & $1.40 \%$ \\
\hline Phenol, 2,4-bis(1,1-dimethylethyl)- & 16.291 & 191 & 91164 & $2.21 \%$ \\
\hline Dodecanoic acid, methyl ester & 16.724 & 74 & 32031 & $0.78 \%$ \\
\hline E-14-Hexadecenal & 18.908 & 55 & 132956 & $3.22 \%$ \\
\hline Tridecanoic acid, 12-methyl-, methyl ester & 24.056 & 74 & 18405 & $0.45 \%$ \\
\hline E-15-Heptadecenal & 26.307 & 55 & 193904 & $4.70 \%$ \\
\hline 9-Hexadecenoic acid, methyl ester, (Z)- & 29.318 & 55 & 38562 & $0.93 \%$ \\
\hline Hexadecanoic acid, methyl ester & 29.912 & 74 & 1754372 & $42.50 \%$ \\
\hline 1-Heneicosanol & 31.551 & 55 & 176606 & $4.28 \%$ \\
\hline n-Heptadecanol-1 & 33.535 & 55 & 9258 & $0.22 \%$ \\
\hline 9,12-Octadecadienoic acid, methyl ester & 33.681 & 67 & 484592 & $11.74 \%$ \\
\hline 9-Octadecenoic acid (Z)-, methyl ester & 33.843 & 55 & 911366 & $22.08 \%$ \\
\hline 11-Octadecenoic acid, methyl ester & 33.95 & 55 & 11021 & $0.27 \%$ \\
\hline Methyl stearate & 34.407 & 74 & 105541 & $2.56 \%$ \\
\hline 1-Heneicosanol & 35.768 & 57 & 81769 & $1.98 \%$ \\
\hline Nonacos-1-ene & 39.436 & 57 & 19057 & $0.46 \%$ \\
\hline
\end{tabular}




\section{Table 2}

Molecular docking scores for the selected compounds and standard drugs 


\begin{tabular}{|c|c|c|c|c|c|}
\hline No. & Compounds & 1R4U & 3GRS & 2 ITY & 5IAE \\
\hline 1. & Cyclopropane, nonyl- & +2.695 & +0.909 & +0.448 & +0.996 \\
\hline 1. & 1-Tetradecene & +4.084 & +3.067 & +2.694 & +3.548 \\
\hline 1. & Phenol, 2,4-bis(1,1-dimethylethyl)- & -4.196 & -5.262 & -5.512 & -5.631 \\
\hline 1. & Dodecanoic acid, methyl ester & +1.391 & +0.475 & +0.584 & -0.154 \\
\hline 1. & E-14-Hexadecenal & +1.157 & +0.066 & +0.178 & +1.212 \\
\hline 1. & $\begin{array}{l}\text { Tridecanoic acid, 12-methyl-, methyl } \\
\text { ester }\end{array}$ & +0.68 & -1.381 & -0.28 & -0.614 \\
\hline 1. & E-15-Heptadecenal & +0.955 & -0.479 & +1.14 & +0.935 \\
\hline 1. & $\begin{array}{l}\text { 9-Hexadecenoic acid, methyl ester, } \\
\text { (Z)- }\end{array}$ & +0.901 & -1.449 & -0.765 & -0.195 \\
\hline 1. & Hexadecanoic acid, methyl ester & +1.507 & -0.447 & -0.001 & -0.029 \\
\hline 1. & 1-Heneicosanol & -2.202 & -3.942 & -3.189 & -2.342 \\
\hline 1. & n-Heptadecanol-1 & +1.612 & +1.01 & +0.115 & +1.486 \\
\hline 1. & $\begin{array}{l}\text { 9,12-Octadecadienoic acid, methyl } \\
\text { ester }\end{array}$ & +0.691 & -1.427 & -1.284 & -0.672 \\
\hline 1. & 9-Octadecenoic acid (Z)-, methyl ester & +1.137 & -0.856 & +0.068 & +0.002 \\
\hline 1. & 11-Octadecenoic acid, methyl ester & +1.022 & -0.312 & -0.497 & -1.088 \\
\hline 1. & Methyl stearate & +1.332 & -0.447 & -0.319 & -0.586 \\
\hline 1. & Nonacos-1-ene & -1.219 & -2.462 & -1.365 & -1.994 \\
\hline 1. & Ascorbic acid & $\begin{array}{l}-4.655 \\
\text { (Ascorbic } \\
\text { acid) }\end{array}$ & $\begin{array}{l}-5.965 \\
\text { (Ascorbic } \\
\text { acid) }\end{array}$ & - & - \\
\hline & 5-Fluorouracil & - & - & -5.218 & -5.2 \\
\hline
\end{tabular}


Table 3

Interaction and bond distances of selected compounds with urate oxidase (PDB: 1R4U) active site 


\begin{tabular}{|c|c|c|c|c|c|}
\hline \multirow[t]{2}{*}{ Protein } & \multirow[t]{2}{*}{ Ligands } & \multicolumn{2}{|c|}{$\begin{array}{l}\text { Hydrogen bond } \\
\text { interactions }\end{array}$} & \multicolumn{2}{|c|}{ Hydrophobic Interactions } \\
\hline & & $\begin{array}{l}\text { Amino acid } \\
\text { residue }\end{array}$ & $\begin{array}{l}\text { Distance } \\
(\AA)\end{array}$ & $\begin{array}{l}\text { Amino acid } \\
\text { residue }\end{array}$ & $\begin{array}{l}\text { Distance } \\
(\AA)\end{array}$ \\
\hline \multirow[t]{26}{*}{ 1R4U } & \multirow[t]{3}{*}{ Cyclopropane, nonyl- } & & & ALA-225 & 5.17 \\
\hline & & & & PHE-159 & 4.60 \\
\hline & & & & PHE-162 & 4.55 \\
\hline & \multirow[t]{4}{*}{ 1-Tetradecene } & & & ARG-176 & 4.42 \\
\hline & & & & PHE-159 & 5.30 \\
\hline & & & & ILE-288 & 5.71 \\
\hline & & & & VAL-227 & 4.00 \\
\hline & \multirow{2}{*}{$\begin{array}{l}\text { Phenol, 2,4-bis(1,1- } \\
\text { dimethylethyl)- }\end{array}$} & LYS-171 & 5.48 & ARG-176 & 5.22 \\
\hline & & & & HIS-256 & 4.68 \\
\hline & \multirow[t]{4}{*}{ Dodecanoic acid, methyl ester } & ASN-254 & 5.21 & ARG-176 & 4.67 \\
\hline & & HIS-256 & 3.68 & TYR-257 & 6.15 \\
\hline & & & & PHE-159 & 5.12 \\
\hline & & & & VAL-227 & 4.26 \\
\hline & \multirow[t]{5}{*}{ E-14-Hexadecenal } & ARG-176 & 7.32 & PHE-159 & 3.41 \\
\hline & & VAL-227 & 3.39 & SER-226 & 4.05 \\
\hline & & & & GLN-228 & 4.59 \\
\hline & & & & ARG-176 & 6.57 \\
\hline & & & & PHE-278 & 6.22 \\
\hline & \multirow{8}{*}{$\begin{array}{l}\text { Tridecanoic acid, 12-methyl-, } \\
\text { methyl ester }\end{array}$} & TYR-257 & 5.48 & TYR-257 & 6.33 \\
\hline & & & & ILE-177 & 4.32 \\
\hline & & & & PHE-278 & 6.24 \\
\hline & & & & ARG-176 & 4.95 \\
\hline & & & & HIS-256 & 4.15 \\
\hline & & & & PHE-159 & 5.13 \\
\hline & & & & VAL-227 & 4.05 \\
\hline & & & & ILE-288 & 4.52 \\
\hline
\end{tabular}




\begin{tabular}{|c|c|c|c|c|}
\hline \multirow[t]{2}{*}{ E-15-Heptadecenal } & ARG-176 & 6.99 & PHE-278 & 6.20 \\
\hline & VAL-227 & 3.93 & & \\
\hline \multirow[t]{6}{*}{$\begin{array}{l}\text { 9-Hexadecenoic acid, methyl } \\
\text { ester, (Z)- }\end{array}$} & HIS-256 & 3.71 & TYR-257 & $\begin{array}{l}4.43 \\
5.83\end{array}$ \\
\hline & ASN-254 & 5.15 & ILE-177 & $\begin{array}{l}3.94 \\
3.72\end{array}$ \\
\hline & TYR-257 & 5.14 & ARG-176 & 4.84 \\
\hline & & & ILE-288 & 5.34 \\
\hline & & & PHE-159 & 5.47 \\
\hline & & & VAL-227 & 4.36 \\
\hline \multirow{8}{*}{$\begin{array}{l}\text { Hexadecanoic acid, methyl } \\
\text { ester }\end{array}$} & ARG-176 & 6.46 & PHE-278 & 5.45 \\
\hline & & & ILE-177 & 3.78 \\
\hline & & & ARG-176 & 5.55 \\
\hline & & & VAL-227 & 3.91 \\
\hline & & & PHE-159 & 5.74 \\
\hline & & & GLN-228 & 4.31 \\
\hline & & & ILE-228 & 5.24 \\
\hline & & & ASN-254 & 4.49 \\
\hline \multirow[t]{2}{*}{ 1-Heneicosanol } & ILE-177 & 3.71 & TYR-257 & 6.91 \\
\hline & TYR-257 & & & \\
\hline \multirow[t]{2}{*}{ n-Heptadecanol-1 } & TYR-257 & 5.34 & VAL-227 & 4.31 \\
\hline & ILE-177 & 3.76 & PHE-159 & 4.61 \\
\hline \multirow[t]{3}{*}{$\begin{array}{l}\text { 9,12-Octadecadienoic acid, } \\
\text { methyl ester }\end{array}$} & HIS-256 & 3.61 & ILE-177 & $\begin{array}{l}4.21 \\
4.41\end{array}$ \\
\hline & & & TYR-257 & 5.08 \\
\hline & & & ARG-176 & 4.76 \\
\hline \multirow{2}{*}{$\begin{array}{l}\text { 9-Octadecenoic acid (Z)-, } \\
\text { methyl ester }\end{array}$} & ASN-254 & 5.19 & ARG-176 & 4.73 \\
\hline & HIS-256 & 3.73 & TYR-257 & $\begin{array}{l}6.24 \\
5.86\end{array}$ \\
\hline \multirow[t]{2}{*}{$\begin{array}{l}\text { 11-Octadecenoic acid, methyl } \\
\text { ester }\end{array}$} & ASN-254 & 5.16 & TYR-257 & $\begin{array}{l}5.81 \\
4.49\end{array}$ \\
\hline & HIS-256 & 3.69 & ARG-176 & 4.87 \\
\hline
\end{tabular}




\begin{tabular}{|c|c|c|c|c|}
\hline & TYR-257 & 0.12 & ILE-177 & $\begin{array}{l}3.91, \\
3.67\end{array}$ \\
\hline \multirow[t]{4}{*}{ Methyl stearate } & ASN-254 & 5.22 & ILE-177 & $\begin{array}{l}3.92 \\
4.08\end{array}$ \\
\hline & HIS-256 & 3.76 & TYR-257 & $\begin{array}{l}5.63 \\
4.34\end{array}$ \\
\hline & & & ARG-176 & 4.66 \\
\hline & & & LEU-163 & 4.15 \\
\hline Nonacos-1-ene & TRP-160 & $\begin{array}{l}4.92 \\
2.78\end{array}$ & HIS-256 & 4.06 \\
\hline \multirow[t]{4}{*}{ Ascorbic acid } & HIS-256 & 4.03 & TYR-257 & 6.50 \\
\hline & ILE-177 & $\begin{array}{l}4.43 \\
3.63\end{array}$ & & \\
\hline & TYR-257 & 5.46 & & \\
\hline & GLU-259 & 4.18 & & \\
\hline
\end{tabular}

Table 4

Interaction and bond distances of selected compounds with glutathione reductase (PDB: 3GRS) active site 


\begin{tabular}{|c|c|c|c|c|c|}
\hline \multirow[t]{2}{*}{ Protein } & \multirow[t]{2}{*}{ Ligands } & \multicolumn{2}{|c|}{$\begin{array}{l}\text { Hydrogen bond } \\
\text { interactions }\end{array}$} & \multicolumn{2}{|c|}{ Hydrophobic Interactions } \\
\hline & & $\begin{array}{l}\text { Amino acid } \\
\text { residue }\end{array}$ & $\begin{array}{l}\text { Distance } \\
(\AA)\end{array}$ & $\begin{array}{l}\text { Amino acid } \\
\text { residue }\end{array}$ & $\begin{array}{l}\text { Distance } \\
(\AA)\end{array}$ \\
\hline \multirow[t]{26}{*}{$3 G R S$} & \multirow[t]{5}{*}{ Cyclopropane, nonyl- } & & & LYS-66 & 4.48 \\
\hline & & & & ILE-198 & 5.13 \\
\hline & & & & PHE-181 & 6.68 \\
\hline & & & & MET-202 & 6.47 \\
\hline & & & & CYS-58 & 4.28 \\
\hline & \multirow[t]{5}{*}{ 1-Tetradecene } & & & ILE-198 & 4.41 \\
\hline & & & & MET-202 & 5.52 \\
\hline & & & & LYS-66 & 4.56 \\
\hline & & & & ALA-342 & 4.87 \\
\hline & & & & ALA-155 & 4.37 \\
\hline & $\begin{array}{l}\text { Phenol, 2,4-bis(1,1- } \\
\text { dimethylethyl)- }\end{array}$ & THR-156 & 4.70 & & \\
\hline & \multirow{2}{*}{$\begin{array}{l}\text { Dodecanoic acid, methyl } \\
\text { ester }\end{array}$} & THR-57 & 3.66 & ALA-155 & 4.34 \\
\hline & & $\mathrm{HOH}-490$ & 3.23 & LYS-66 & 4.01 \\
\hline & \multirow[t]{4}{*}{ E-14-Hexadecenal } & THR-57 & 3.74 & MET-202 & 4.81 \\
\hline & & & & ILE-198 & 4.93 \\
\hline & & & & LYS-66 & 4.67 \\
\hline & & & & PHE-181 & 6.20 \\
\hline & \multirow{7}{*}{$\begin{array}{l}\text { Tridecanoic acid, 12-methyl-, } \\
\text { methyl ester }\end{array}$} & $\mathrm{HOH}-482$ & 2.74 & PHE-181 & 6.21 \\
\hline & & ASP-331 & 3.52 & LYS-66 & 4.77 \\
\hline & & & & MET-202 & 4.65 \\
\hline & & & & ILE-198 & 4.37 \\
\hline & & & & GLY-157 & 3.72 \\
\hline & & & & GLY-330 & 4.71 \\
\hline & & & & ALA-155 & 4.06 \\
\hline & \multirow[t]{2}{*}{ E-15-Heptadecenal } & THR-57 & 3.80 & ILE-198 & 4.95 \\
\hline & & $\mathrm{HOH}-490$ & 3.15 & PHE-181 & 5.91 \\
\hline
\end{tabular}




\begin{tabular}{|c|c|c|c|c|}
\hline & & & LYS-66 & 5.24 \\
\hline & & & MET-202 & 4.73 \\
\hline \multirow{5}{*}{$\begin{array}{l}\text { 9-Hexadecenoic acid, methyl } \\
\text { ester, (Z)- }\end{array}$} & $\mathrm{HOH}-484$ & 2.51 & PHE-181 & 6.27 \\
\hline & SER-30 & 3.94 & MET-202 & 6.01 \\
\hline & GLY-31 & 4.05 & LYS-66 & 4.17 \\
\hline & & & GLY-157 & 3.53 \\
\hline & & & ALA-155 & 4.50 \\
\hline \multirow{5}{*}{$\begin{array}{l}\text { Hexadecanoic acid, methyl } \\
\text { ester }\end{array}$} & THR-339 & 3.86 & CYS-63 & 6.07 \\
\hline & & & LEU-337 & 5.53 \\
\hline & & & LEU-338 & 3.98 \\
\hline & & & LEU-33 & 4.45 \\
\hline & & & TYR-114 & 5.22 \\
\hline \multirow[t]{2}{*}{ 1-Heneicosanol } & THR-97 & 3.63 & VAL-370 & 5.16 \\
\hline & $\mathrm{HOH}-490$ & 3.22 & LEU-444 & 4.46 \\
\hline \multirow[t]{2}{*}{ n-Heptadecanol-1 } & THR-339 & 3.98 & TYR-114 & 4.86 \\
\hline & & & LEU-33 & 4.11 \\
\hline \multirow{4}{*}{$\begin{array}{l}9,12-0 \text { ctadecadienoic acid, } \\
\text { methyl ester }\end{array}$} & THR-339 & 3.71 & CYS-63 & 4.79 \\
\hline & & & TYR-197 & $\begin{array}{l}6.22,6.63, \\
5.92\end{array}$ \\
\hline & & & LEU-338 & $5.16,4.00$ \\
\hline & & & PRO-340 & 4.98 \\
\hline \multirow{4}{*}{$\begin{array}{l}\text { 9-Octadecenoic acid (Z)-, } \\
\text { methyl ester }\end{array}$} & LYS-66 & 5.27 & LEU-338 & 5.88 \\
\hline & & & TYR-197 & 4.64 \\
\hline & & & LEU-33 & 4.11 \\
\hline & & & TYR-114 & 4.83 \\
\hline \multirow{5}{*}{$\begin{array}{l}\text { 11-Octadecenoic acid, methyl } \\
\text { ester }\end{array}$} & THR-339 & 4.20 & LEU-338 & 4.12 \\
\hline & & & CYS-63 & 5.80 \\
\hline & & & VAL-59 & 5.39 \\
\hline & & & TYR-114 & 5.45 \\
\hline & & & LEU-33 & 6.61 \\
\hline
\end{tabular}




\begin{tabular}{llll|}
\hline Methyl stearate & 4.10 & PHE-181 & 5.52 \\
\cline { 2 - 4 } & & ILE-198 & 5.20 \\
\hline & & MET-202 & 4.89 \\
\hline & & GLU-50 & $4.62,5.27$ \\
\hline & & GLY-56 & 3.89 \\
\hline Nonacos-1-ene & & LYS-114 & 5.85 \\
\hline & & GLY-29 & 4.58 \\
\hline Ascorbic acid & & ALA-34 & 4.33 \\
\hline THR-57 & 3.67 & & \\
\hline GLU-50 & $4.60,4.15$ & \\
\hline HOH-490 & 3.93 & \\
\hline ALA-155 & 4.11 & \\
\hline
\end{tabular}

\section{Table 5}

Interaction and bond distances of selected compounds with EGFR kinase domain (PDB: 2ITY) active site 


\begin{tabular}{|c|c|c|c|c|c|}
\hline \multirow[t]{2}{*}{ Protein } & \multirow[t]{2}{*}{ Ligands } & \multicolumn{2}{|c|}{$\begin{array}{l}\text { Hydrogen bond } \\
\text { interactions }\end{array}$} & \multicolumn{2}{|c|}{ Hydrophobic Interactions } \\
\hline & & $\begin{array}{l}\text { Amino acid } \\
\text { residue }\end{array}$ & $\begin{array}{l}\text { Distance } \\
(\AA)\end{array}$ & $\begin{array}{l}\text { Amino acid } \\
\text { residue }\end{array}$ & $\begin{array}{l}\text { Distance } \\
(\AA)\end{array}$ \\
\hline \multirow[t]{26}{*}{ 2ITY } & \multirow[t]{4}{*}{ Cyclopropane, nonyl- } & & & LYS-745 & 4.50 \\
\hline & & & & LEU-788 & 5.31 \\
\hline & & & & MET-766 & 6.76 \\
\hline & & & & LEU-718 & 4.75 \\
\hline & \multirow[t]{2}{*}{ 1-Tetradecene } & & & LEU-718 & 5.02 \\
\hline & & & & LYS-745 & 3.96 \\
\hline & \multirow{3}{*}{$\begin{array}{l}\text { Phenol, 2,4-bis(1,1- } \\
\text { dimethylethyl)- }\end{array}$} & ASP-855 & 4.01 & LEU-718 & 5.60 \\
\hline & & & & VAL-726 & $5.78,5.65$ \\
\hline & & & & LEU-844 & $6.15,5.63$ \\
\hline & \multirow[t]{3}{*}{ Dodecanoic acid, methyl ester } & & & THR-854 & 3.78 \\
\hline & & & & ASP-855 & 3.76 \\
\hline & & & & LYS-745 & 3.14 \\
\hline & \multirow[t]{3}{*}{ E-14-Hexadecenal } & LYS-716 & 5.37 & LYS-728 & 5.45 \\
\hline & & & & LYS-745 & 4.18 \\
\hline & & & & LEU-788 & 3.84 \\
\hline & \multirow{5}{*}{$\begin{array}{l}\text { Tridecanoic acid, 12-methyl-, } \\
\text { methyl ester }\end{array}$} & & & MET-766 & 5.82 \\
\hline & & & & LEU-788 & $\begin{array}{l}2.64,3.65, \\
4.22\end{array}$ \\
\hline & & & & LYS-745 & 2.85 \\
\hline & & & & LEU-792 & 4.93 \\
\hline & & & & LEU-718 & $5.14,4.92$ \\
\hline & \multirow[t]{2}{*}{ E-15-Heptadecenal } & LYS-716 & 5.50 & LEU-788 & 3.91 \\
\hline & & & & LYS-745 & 3.89 \\
\hline & \multirow{3}{*}{$\begin{array}{l}\text { 9-Hexadecenoic acid, methyl } \\
\text { ester, (Z)- }\end{array}$} & LYS-716 & 5.50 & LEU-788 & 3.62 \\
\hline & & & & LYS-745 & 4.09 \\
\hline & & & & MET-766 & 6.43 \\
\hline & Hexadecanoic acid, methyl & $\begin{array}{l}\text { LYS-716 } \\
\text { Page 37/69 }\end{array}$ & 5.42 & LYS-728 & 5.98 \\
\hline
\end{tabular}


ester

\begin{tabular}{|c|c|c|c|}
\hline & & LEU-788 & 3.47 \\
\hline & & MET-766 & 5.97 \\
\hline \multirow[t]{4}{*}{ GLU-804 } & 4.20 & GLU-804 & 4.13 \\
\hline & & HIS-805 & 4.61 \\
\hline & & LYS-745 & 3.95 \\
\hline & & LEU-788 & 3.84 \\
\hline LYS-745 & 4.77 & THR-854 & 3.78 \\
\hline \multirow[t]{2}{*}{ ASP-855 } & 3.37 & TYR-801 & 4.20 \\
\hline & & HIS-805 & 5.72 \\
\hline
\end{tabular}

\begin{tabular}{|c|c|c|c|c|}
\hline \multirow{5}{*}{$\begin{array}{l}\text { 9,12-Octadecadienoic acid, } \\
\text { methyl ester }\end{array}$} & LYS-716 & 5.42 & LYS-728 & 5.19 \\
\hline & & & PRO-794 & $4.71,5.68$ \\
\hline & & & LYS-745 & 4.14 \\
\hline & & & MET-766 & 6.14 \\
\hline & & & LEU-788 & 4.04 \\
\hline \multirow{7}{*}{$\begin{array}{l}\text { 9-Octadecenoic acid (Z)-, } \\
\text { methyl ester }\end{array}$} & & & LEU-718 & 5.01 \\
\hline & & & LEU-792 & 5.15 \\
\hline & & & GLY-724 & 3.19 \\
\hline & & & GLY-721 & 3.99 \\
\hline & & & ALA-722 & 4.99 \\
\hline & & & GLY-719 & 4.19 \\
\hline & & & VAL-726 & 5.12 \\
\hline \multirow{3}{*}{$\begin{array}{l}\text { 11-Octadecenoic acid, methyl } \\
\text { ester }\end{array}$} & LYS-716 & 5.50 & LYS-728 & 5.63 \\
\hline & & & ALA-743 & 3.84 \\
\hline & & & LYS-745 & 4.35 \\
\hline \multirow[t]{3}{*}{ Methyl stearate } & LYS-728 & 5.69 & GLU-1004 & $3.91,5.24$ \\
\hline & LYS-716 & 4.91 & MET-766 & 5.71 \\
\hline & & & LEU-788 & 5.14 \\
\hline \multirow[t]{2}{*}{ Nonacos-1-ene } & & & LYS-728 & 3.44 \\
\hline & & & ILE-715 & 4.32 \\
\hline
\end{tabular}




\section{Table 6}

Interaction and bond distances of selected compounds with Caspase 3 (PDB: 5IAE) active site 


\begin{tabular}{|c|c|c|c|c|c|}
\hline \multirow[t]{2}{*}{ Protein } & \multirow[t]{2}{*}{ Ligands } & \multicolumn{2}{|c|}{$\begin{array}{l}\text { Hydrogen bond } \\
\text { interactions }\end{array}$} & \multicolumn{2}{|c|}{ Hydrophobic Interactions } \\
\hline & & $\begin{array}{l}\text { Amino acid } \\
\text { residue }\end{array}$ & $\begin{array}{l}\text { Distance } \\
(\AA)\end{array}$ & $\begin{array}{l}\text { Amino acid } \\
\text { residue }\end{array}$ & $\begin{array}{l}\text { Distance } \\
(\AA)\end{array}$ \\
\hline \multirow[t]{24}{*}{$5 \mathrm{IAE}$} & \multirow[t]{2}{*}{ Cyclopropane, nonyl- } & & & TYR-204 & 2.89 \\
\hline & & & & TRP-206 & 4.80 \\
\hline & \multirow[t]{2}{*}{ 1-Tetradecene } & & & MET-61 & 4.37 \\
\hline & & & & PHE-128 & 6.49 \\
\hline & \multirow[t]{2}{*}{$\begin{array}{l}\text { Phenol, 2,4-bis(1,1- } \\
\text { dimethylethyl)- }\end{array}$} & ARG-207 & 3.53 & TRP-206 & $\begin{array}{l}5.90 \\
4.71\end{array}$ \\
\hline & & & & TYR-204 & 4.62 \\
\hline & \multirow[t]{5}{*}{ Dodecanoic acid, methyl ester } & ASN-208 & 3.79 & GLU-248 & 5.92 \\
\hline & & TRP-214 & 5.23 & TRP-206 & 4.29 \\
\hline & & PHE-250 & 5.33 & TYR-204 & 3.46 \\
\hline & & & & PHE-256 & 5.22 \\
\hline & & & & LEU-168 & 5.51 \\
\hline & \multirow[t]{2}{*}{ E-14-Hexadecenal } & ARG-64 & 4.21 & SER-205 & 4.08 \\
\hline & & ARG-207 & 3.74 & PHE-256 & 4.91 \\
\hline & \multirow{7}{*}{$\begin{array}{l}\text { Tridecanoic acid, 12-methyl-, } \\
\text { methyl ester }\end{array}$} & TRP-214 & 5.18 & TRP-214 & 5.45 \\
\hline & & ASN-208 & 4.07 & GLU-248 & 5.32 \\
\hline & & PHE-250 & 5.85 & SER-249 & 4.01 \\
\hline & & PHE-256 & 5.14 & & \\
\hline & & LEU-168 & 5.27 & & \\
\hline & & TYR-204 & $\begin{array}{l}3.48 \\
4.74\end{array}$ & & \\
\hline & & TRP-206 & $\begin{array}{l}3.46 \\
4.21\end{array}$ & & \\
\hline & \multirow[t]{2}{*}{ E-15-Heptadecenal } & ARG-64 & 3.93 & PRO-133 & 5.54 \\
\hline & & ARG-207 & 3.90 & & \\
\hline & \multirow[t]{2}{*}{$\begin{array}{l}\text { 9-Hexadecenoic acid, methyl } \\
\text { ester, (Z)- }\end{array}$} & PHE-250 & 5.35 & GLU-248 & $\begin{array}{l}5.46 \\
5.34\end{array}$ \\
\hline & & ASN-208 & 3.71 & HIS-121 & 4.14 \\
\hline
\end{tabular}




\begin{tabular}{|c|c|c|c|c|}
\hline & TRP-214 & 5.28 & CYS-163 & 4.26 \\
\hline \multirow{6}{*}{$\begin{array}{l}\text { Hexadecanoic acid, methyl } \\
\text { ester }\end{array}$} & TRP-214 & 3.74 & TRP-214 & 4.76 \\
\hline & ASN-208 & 5.02 & PHE-247 & 4.52 \\
\hline & & & PHE-256 & 5.12 \\
\hline & & & TYR-204 & 3.50 \\
\hline & & & LEU-168 & 5.20 \\
\hline & & & TRP-206 & 4.17 \\
\hline 1-Heneicosanol & ARG-64 & 4.66 & SER-120 & 5.18 \\
\hline \multirow[t]{2}{*}{ n-Heptadecanol-1 } & ARG-64 & 4.81 & SER-205 & 3.61 \\
\hline & SER-120 & 4.75 & & \\
\hline \multirow{3}{*}{$\begin{array}{l}\text { 9,12-Octadecadienoic acid, } \\
\text { methyl ester }\end{array}$} & ASN-208 & 3.49 & SER-249 & 4.44 \\
\hline & TRP-214 & 5.49 & CYS-163 & 4.20 \\
\hline & PHE-250 & 5.50 & & \\
\hline \multirow{2}{*}{$\begin{array}{l}\text { 9-Octadecenoic acid (Z)-, } \\
\text { methyl ester }\end{array}$} & ASN-208 & 3.73 & GLU-248 & 5.75 \\
\hline & TRP-214 & 5.07 & SER-249 & 4.20 \\
\hline \multirow{4}{*}{$\begin{array}{l}\text { 11-Octadecenoic acid, methyl } \\
\text { ester }\end{array}$} & PHE-250 & 5.49 & SER-249 & 4.30 \\
\hline & TRP-214 & 5.35 & MET-61 & 4.78 \\
\hline & ASN-208 & 3.54 & PHE-128 & 5.20 \\
\hline & & & HIS-121 & 4.82 \\
\hline \multirow[t]{4}{*}{ Methyl stearate } & PHE-250 & 5.44 & TRP-214 & 6.45 \\
\hline & TRP-214 & 5.19 & GLU-248 & $\begin{array}{l}5.36, \\
5.29\end{array}$ \\
\hline & & & MET-61 & 4.78 \\
\hline & & & PHE-128 & 6.32 \\
\hline Nonacos-1-ene & & & CYS-161 & 4.76 \\
\hline \multirow[t]{3}{*}{ 5-fluorouracil } & SER-120 & 4.67 & HIS-121 & 3.51 \\
\hline & GLN-161 & 3.89 & CYS-163 & 5.84 \\
\hline & ARG-64 & 4.89 & & \\
\hline
\end{tabular}




\section{Table 7}

Physicochemical properties of the isolated compound from EAF for good oral bioavailability.

\begin{tabular}{|lllllllll|}
\hline Compound & \multicolumn{2}{l}{ Lipinski Rules } & & & & Lipinski's \\
& MW & HBA & HBD & Log & MR & Violations \\
& & & & P & & \\
\hline Cyclopropane, nonyl- & 168.32 & 0 & 0 & 4.73 & 57.68 & 0 \\
\hline 1-Tetradecene & 193.37 & 0 & 0 & 5.71 & 68.94 & 1 \\
\hline Phenol,2,4-bis(1,1-dimethylethyl)- & 206.32 & 1 & 1 & 3.09 & 67.01 & 0 \\
\hline Dodecanoic acid, methyl ester & 214.34 & 2 & 0 & 4.10 & 65.89 & 0 \\
\hline E-14-Hexadecenal & 238.41 & 1 & 0 & 5.13 & 78.75 & 1 \\
\hline $\begin{array}{l}\text { Tridecanoic acid, 12-methyl-, methyl } \\
\text { ester }\end{array}$ & 242.40 & 2 & 0 & 4.75 & 75.50 & 0 \\
\hline E-15-Heptadecenal & 252.44 & 1 & 0 & 5.50 & 83.56 & 1 \\
\hline 9-Hexadecenoic acid, methyl ester, (Z)- & 268.43 & 2 & 0 & 5.26 & 84.64 & 1 \\
\hline Hexadecanoic acid, methyl ester & 270.45 & 2 & 9 & 5.54 & 85.12 & 2 \\
\hline 1-Heneicosanol & 312.57 & 1 & 1 & 7.25 & 104.22 & 1 \\
\hline n-Heptadecanol-1 & 256.5 & 1 & 1 & 7.8 & 82.34 & 1 \\
\hline 9,12-Octadecadienoic acid, methyl ester & 294.47 & 2 & 0 & 5.69 & 93.98 & 1 \\
\hline 9-Octadecenoic acid (Z)-, methyl ester & 296.49 & 2 & 0 & 5.95 & 94.26 & 1 \\
\hline 11-Octadecenoic acid, methyl ester & 296.49 & 2 & 9 & 5.95 & 94.26 & 2 \\
\hline Methyl stearate & 298.50 & 2 & 0 & 6.24 & 94.73 & 1 \\
\hline Nonacos-1-ene & 406.77 & 0 & 0 & 11.21 & 141.04 & 2 \\
\hline $\begin{array}{l}\text { MW, Molecular weight (g/mol); HBA, Hydrogen bond } \\
\text { Lipophilicity; MR, Molar refractivity. }\end{array}$ & & & & & & \\
\hline
\end{tabular}

Table 8 Toxicological properties identified compounds from EAF fraction. 


\begin{tabular}{|c|c|c|c|c|}
\hline \multirow[b]{2}{*}{ Compound } & \multicolumn{4}{|c|}{ Parameters } \\
\hline & $\begin{array}{l}\text { Ames } \\
\text { toxicity }\end{array}$ & Carcinogens & $\begin{array}{l}\text { Acute } \\
\text { oral }\end{array}$ & $\begin{array}{l}\text { Rat Acute } \\
\text { Toxicity }\end{array}$ \\
\hline Cyclopropane, nonyl- & NAT & NC & III & 1.5283 \\
\hline 1-Tetradecene & NAT & Carcinogens & III & 1.3452 \\
\hline Phenol, 2,4-bis(1,1-dimethylethyl)- & NAT & NC & III & 2.2064 \\
\hline Dodecanoic acid, methyl ester & NAT & Carcinogens & III & 1.4915 \\
\hline E-14-Hexadecenal & NAT & $\mathrm{NC}$ & III & 1.6100 \\
\hline $\begin{array}{l}\text { Tridecanoic acid, 12-methyl-, methyl } \\
\text { ester }\end{array}$ & NAT & NC & III & 1.5702 \\
\hline E-15-Heptadecenal & NAT & NC & III & 1.6100 \\
\hline $\begin{array}{l}\text { 9-Hexadecenoic acid, methyl ester, } \\
\text { (Z)- }\end{array}$ & NAT & Carcinogens & III & 1.7357 \\
\hline Hexadecanoic acid, methyl ester & NAT & Carcinogens & III & 1.4915 \\
\hline 1-Heneicosanol & NAT & NC & III & 1.5561 \\
\hline n-Heptadecanol-1 & NAT & NC & III & 1.5561 \\
\hline $\begin{array}{l}\text { 9,12-0ctadecadienoic acid, methyl } \\
\text { ester }\end{array}$ & NAT & Carcinogens & III & 1.7357 \\
\hline 9-Octadecenoic acid (Z)-, methyl ester & NAT & Carcinogens & III & 1.7357 \\
\hline 11-Octadecenoic acid, methyl ester & NAT & Carcinogens & III & 1.7357 \\
\hline Methyl stearate & NAT & Carcinogens & III & 1.4915 \\
\hline Nonacos-1-ene & NAT & Carcinogens & III & 1.3452 \\
\hline $\begin{array}{l}\text { NAT, Non Ames toxic; NC, Non-carcinog } \\
\text { II }\left(50 \mathrm{mg} / \mathrm{kg}<\mathrm{LD}_{50}<500 \mathrm{mg} / \mathrm{kg}\right) ; \text { Cate } \\
\left(5000 \mathrm{mg} / \mathrm{kg}<\mathrm{LD}_{50}\right)\end{array}$ & ic; Cate & $\begin{array}{l}b_{50} \leq 50 \mathrm{mg} / \\
<L_{50}<500\end{array}$ & $\begin{array}{l}\text {; Cate } \\
\text { hg/kg); }\end{array}$ & ory- IV \\
\hline
\end{tabular}

Table 9

Biological activities predicted for identified compounds by PASS online. 


\begin{tabular}{|c|c|c|c|c|}
\hline Name & Characteristics & $\begin{array}{l}\text { Biological Properties Predicted } \\
\text { by Pass Online }\end{array}$ & $\mathrm{P}_{\mathrm{a}}$ & $P_{i}$ \\
\hline \multirow[t]{23}{*}{ Cyclopropane, nonyl- } & \multirow[t]{14}{*}{ Antioxidant } & Free radical scavenger & 0.181 & 0.093 \\
\hline & & Peroxidase substrate & 0.400 & 0.020 \\
\hline & & Reductant & 0.461 & 0.033 \\
\hline & & Lipid peroxidase inhibitor & 0.322 & 0.057 \\
\hline & & Antiviral (Parainfluenza) & 0.065 & 0.012 \\
\hline & & Antiviral (Influenza) & 0.572 & 0.015 \\
\hline & & Antiviral (Rhinovirus) & 0.595 & 0.007 \\
\hline & & Antiviral (Picornavirus) & 0.699 & 0.005 \\
\hline & & Antiviral (Adenovirus) & 0.395 & 0.031 \\
\hline & & Antiviral (CMV) & 0.376 & 0.007 \\
\hline & & Antiviral (Herpes) & 0.396 & 0.037 \\
\hline & & Antiviral (Influenza A) & 0.261 & 0.081 \\
\hline & & Antiviral (Hepatitis) & 0.111 & 0.084 \\
\hline & & Antiviral (Poxvirus) & 0.333 & 0.045 \\
\hline & \multirow[t]{9}{*}{ Anticancer } & Antineoplastic, Alkylator & 0.156 & 0.033 \\
\hline & & $\begin{array}{l}\text { Antineoplastic (endocrine } \\
\text { cancer) }\end{array}$ & 0.178 & 0.073 \\
\hline & & Antineoplastic (bone cancer) & 0.283 & 0.010 \\
\hline & & Antineoplastic (thyroid cancer) & 0.181 & 0.053 \\
\hline & & $\begin{array}{l}\text { Antineoplastic (non-Hodgkin's } \\
\text { lymphoma) }\end{array}$ & 0.381 & 0.126 \\
\hline & & $\begin{array}{l}\text { Antineoplastic (multiple } \\
\text { myeloma) }\end{array}$ & 0.271 & 0.115 \\
\hline & & Antineoplastic antimetabolite & 0.119 & 0.073 \\
\hline & & Antineoplastic (sarcoma) & 0.166 & 0.113 \\
\hline & & Antineoplastic (insulinoma) & 0.014 & 0.008 \\
\hline \multirow[t]{3}{*}{ 1-Tetradecene } & \multirow[t]{3}{*}{ Antioxidant } & Antioxidant & 0.282 & 0.027 \\
\hline & & Free radical scavenger & 0.286 & 0.034 \\
\hline & & Reductant & 0.461 & 0.033 \\
\hline
\end{tabular}




\begin{tabular}{|c|c|c|c|c|}
\hline & & Lipid peroxidase inhibitor & 0.364 & 0.046 \\
\hline & \multirow[t]{13}{*}{ Antiviral } & Antiviral & 0.197 & 0.099 \\
\hline & & Antiviral (Influenza) & 0.396 & 0.048 \\
\hline & & Antiviral (Rhinovirus) & 0.651 & 0.004 \\
\hline & & Antiviral (Picornavirus) & 0.542 & 0.035 \\
\hline & & Antiviral (Adenovirus) & 0.417 & 0.023 \\
\hline & & Antiviral (CMV) & 0.512 & 0.002 \\
\hline & & Antiviral (Herpes) & 0.417 & 0.028 \\
\hline & & Antiviral (Hepatitis B) & 0.173 & 0.127 \\
\hline & & Antiviral (Poxvirus) & 0.279 & 0.071 \\
\hline & & $\begin{array}{l}\text { Antiviral (Herpesvirus 3, } \\
\text { Human) }\end{array}$ & 0.023 & 0.003 \\
\hline & & Antiviral (Hepatitis) & 0.169 & 0.023 \\
\hline & & Antiviral (Hepatitis C) & 0.144 & 0.020 \\
\hline & & Antiviral (Parainfluenza) & 0.076 & 0.008 \\
\hline & \multirow[t]{5}{*}{ Anticancer } & $\begin{array}{l}\text { Antineoplastic (endocrine } \\
\text { cancer) }\end{array}$ & 0.216 & 0.037 \\
\hline & & Antineoplastic (thyroid cancer) & 0.214 & 0.023 \\
\hline & & Antineoplastic, alkylator & 0.128 & 0.049 \\
\hline & & Antineoplastic antimetabolite & 0.134 & 0.059 \\
\hline & & Antineoplastic (liver cancer) & 0.263 & 0.035 \\
\hline \multirow{9}{*}{$\begin{array}{l}\text { Phenol, 2,4-bis(1,1- } \\
\text { dimethylethyl)- }\end{array}$} & \multirow[t]{5}{*}{ Antioxidant } & Antioxidant & 0.525 & 0.006 \\
\hline & & Free radical scavenger & 0.532 & 0.009 \\
\hline & & Peroxidase substrate & 0.703 & 0.003 \\
\hline & & Reductant & 0.808 & 0.004 \\
\hline & & Lipid peroxidase inhibitor & 0.629 & 0.008 \\
\hline & \multirow[t]{4}{*}{ Antiviral } & Antiviral & 0.181 & 0.119 \\
\hline & & Antiviral (Influenza) & 0.471 & 0.028 \\
\hline & & Antiviral (Rhinovirus) & 0.299 & 0.254 \\
\hline & & Antiviral (Picornavirus) & 0.425 & 0.091 \\
\hline
\end{tabular}




\begin{tabular}{|c|c|c|c|c|}
\hline & & Antiviral (Adenovirus) & 0.369 & 0.043 \\
\hline & & Antiviral (CMV) & 0.274 & 0.049 \\
\hline & & Antiviral (Herpes) & 0.275 & 0.110 \\
\hline & & Antiviral (Poxvirus) & 0.274 & 0.075 \\
\hline & & Antiviral (Parainfluenza) & 0.039 & 0.037 \\
\hline & Anticancer & $\begin{array}{l}\text { Antineoplastic (squamous cell } \\
\text { carcinoma) }\end{array}$ & 0.133 & 0.043 \\
\hline & & Antineoplastic (bladder cancer) & 0.165 & 0.097 \\
\hline & & Antineoplastic (bone cancer) & 0.199 & 0.160 \\
\hline & & Antineoplastic, alkylator & 0.102 & 0.074 \\
\hline & & Antineoplastic alkaloid & 0.166 & 0.149 \\
\hline & & Antineoplastic (cervical cancer) & 0.103 & 0.095 \\
\hline Dodecanoic acid, methyl ester & Antioxidant & Antioxidant & 0.210 & 0.050 \\
\hline & & Free radical scavenger & 0.332 & 0.025 \\
\hline & & Peroxidase substrate & 0.424 & 0.017 \\
\hline & & Reductant & 0.523 & 0.020 \\
\hline & & Lipid peroxidase inhibitor & 0.292 & 0.067 \\
\hline & Antiviral & Antiviral & 0.176 & 0.125 \\
\hline & & Antiviral (Influenza) & 0.417 & 0.041 \\
\hline & & Antiviral (Influenza A) & 0.227 & 0.145 \\
\hline & & Antiviral (Rhinovirus) & 0.616 & 0.005 \\
\hline & & Antiviral (Picornavirus) & 0.554 & 0.031 \\
\hline & & Antiviral (Adenovirus) & 0.425 & 0.020 \\
\hline & & Antiviral (CMV) & 0.438 & 0.004 \\
\hline & & Antiviral (Herpes) & 0.392 & 0.039 \\
\hline & & $\begin{array}{l}\text { Antiviral (Herpesvirus 3, } \\
\text { Human) }\end{array}$ & 0.012 & 0.008 \\
\hline & & Antiviral (Hepatitis B) & 0.219 & 0.070 \\
\hline & & Antiviral (Parainfluenza) & 0.072 & 0.009 \\
\hline & Anticancer & $\begin{array}{l}\text { Antineoplastic (non-Hodgkin's } \\
\text { lymphoma) }\end{array}$ & 0.409 & 0.099 \\
\hline
\end{tabular}




\begin{tabular}{|c|c|c|c|c|}
\hline & & $\begin{array}{l}\text { Antineoplastic (endocrine } \\
\text { cancer) }\end{array}$ & 0.214 & 0.038 \\
\hline & & Antineoplastic (thyroid cancer) & 0.222 & 0.019 \\
\hline & & Antineoplastic, alkylator & 0.218 & 0.016 \\
\hline & & Antineoplastic antimetabolite & 0.205 & 0.032 \\
\hline & & Antineoplastic (liver cancer) & 0.215 & 0.069 \\
\hline & & Antineoplastic (solid tumors) & 0.238 & 0.154 \\
\hline & & Antineoplastic (sarcoma) & 0.165 & 0.117 \\
\hline & & Antineoplastic (insulinoma) & 0.012 & 0.009 \\
\hline & & Antineoplastic (bladder cancer) & 0.156 & 0.117 \\
\hline E-14-Hexadecenal & Antioxidant & Antioxidant & 0.164 & 0.086 \\
\hline & & Free radical scavenger & 0.185 & 0.089 \\
\hline & & Peroxidase substrate & 0.471 & 0.012 \\
\hline & & Reductant & 0.346 & 0.068 \\
\hline & & Lipid peroxidase inhibitor & 0.202 & 0.131 \\
\hline & Antiviral & Antiviral & 0.177 & 0.124 \\
\hline & & Antiviral (Influenza) & 0.434 & 0.036 \\
\hline & & Antiviral (Influenza A) & 0.233 & 0.132 \\
\hline & & Antiviral (Rhinovirus) & 0.497 & 0.025 \\
\hline & & Antiviral (Picornavirus) & 0.445 & 0.078 \\
\hline & & Antiviral (Adenovirus) & 0.334 & 0.064 \\
\hline & & Antiviral (CMV) & 0.343 & 0.012 \\
\hline & & Antiviral (Herpes) & 0.390 & 0.040 \\
\hline & & $\begin{array}{l}\text { Antiviral (Herpesvirus 3, } \\
\text { Human) }\end{array}$ & 0.015 & 0.004 \\
\hline & & Antiviral (Poxvirus) & 0.225 & 0.123 \\
\hline & & Antiviral (Parainfluenza) & 0.042 & 0.032 \\
\hline & Anticancer & Antineoplastic (brain cancer) & 0.223 & 0.089 \\
\hline & & Antineoplastic antibiotic & 0.139 & 0.035 \\
\hline & & Antineoplastic (bone cancer) & 0.192 & 0.182 \\
\hline
\end{tabular}




\begin{tabular}{|c|c|c|c|c|}
\hline & & Antineoplastic, alkylator & 0.161 & 0.031 \\
\hline & & Antineoplastic antimetabolite & 0.119 & 0.073 \\
\hline \multirow{26}{*}{$\begin{array}{l}\text { Tridecanoic acid, 12-methyl-, } \\
\text { methyl ester }\end{array}$} & \multirow[t]{5}{*}{ Antioxidant } & Antioxidant & 0.243 & 0.038 \\
\hline & & Free radical scavenger & 0.312 & 0.028 \\
\hline & & Peroxidase substrate & 0.396 & 0.020 \\
\hline & & Reductant & 0.384 & 0.055 \\
\hline & & Lipid peroxidase inhibitor & 0.302 & 0.063 \\
\hline & \multirow[t]{11}{*}{ Antiviral } & Antiviral & 0.234 & 0.070 \\
\hline & & Antiviral (Influenza) & 0.388 & 0.050 \\
\hline & & Antiviral (Influenza A) & 0.282 & 0.056 \\
\hline & & Antiviral (Rhinovirus) & 0.595 & 0.007 \\
\hline & & Antiviral (Picornavirus) & 0.482 & 0.058 \\
\hline & & Antiviral (Adenovirus) & 0.404 & 0.028 \\
\hline & & Antiviral (CMV) & 0.379 & 0.006 \\
\hline & & Antiviral (Herpes) & 0.394 & 0.038 \\
\hline & & Antiviral (Hepatitis B) & 0.243 & 0.054 \\
\hline & & Antiviral (Poxvirus) & 0.253 & 0.093 \\
\hline & & Antiviral (Parainfluenza) & 0.056 & 0.017 \\
\hline & \multirow[t]{10}{*}{ Anticancer } & $\begin{array}{l}\text { Antineoplastic (non-Hodgkin's } \\
\text { lymphoma) }\end{array}$ & 0.478 & 0.047 \\
\hline & & $\begin{array}{l}\text { Antineoplastic (endocrine } \\
\text { cancer) }\end{array}$ & 0.252 & 0.025 \\
\hline & & Antineoplastic (bone cancer) & 0.255 & 0.027 \\
\hline & & Antineoplastic (thyroid cancer) & 0.209 & 0.025 \\
\hline & & Antineoplastic, alkylator & 0.171 & 0.027 \\
\hline & & Antineoplastic antimetabolite & 0.159 & 0.044 \\
\hline & & Antineoplastic (liver cancer) & 0.186 & 0.103 \\
\hline & & Antineoplastic (solid tumors) & 0.227 & 0.170 \\
\hline & & Antineoplastic antibiotic & 0.078 & 0.063 \\
\hline & & Antineoplastic (insulinoma) & 0.017 & 0.005 \\
\hline
\end{tabular}




\begin{tabular}{|c|c|c|c|c|}
\hline E-15-Heptadecenal & Antioxidant & Antioxidant & 0.164 & 0.086 \\
\hline & & Free radical scavenger & 0.185 & 0.089 \\
\hline & & Peroxidase substrate & 0.471 & 0.012 \\
\hline & & Reductant & 0.346 & 0.068 \\
\hline & & Lipid peroxidase inhibitor & 0.202 & 0.131 \\
\hline & Antiviral & Antiviral & 0.177 & 0.124 \\
\hline & & Antiviral (Rhinovirus) & 0.497 & 0.025 \\
\hline & & Antiviral (Picornavirus) & 0.445 & 0.078 \\
\hline & & Antiviral (Adenovirus) & 0.334 & 0.064 \\
\hline & & Antiviral (CMV) & 0.343 & 0.012 \\
\hline & & Antiviral (Herpes) & 0.390 & 0.040 \\
\hline & & $\begin{array}{l}\text { Antiviral (Herpesvirus 3, } \\
\text { Human) }\end{array}$ & 0.015 & 0.004 \\
\hline & & Antiviral (Poxvirus) & 0.225 & 0.123 \\
\hline & & Antiviral (Parainfluenza) & 0.042 & 0.032 \\
\hline & Anticancer & Antineoplastic (brain cancer) & 0.223 & 0.089 \\
\hline & & Antineoplastic, alkylator & 0.161 & 0.031 \\
\hline & & Antineoplastic antimetabolite & 0.119 & 0.073 \\
\hline & & Antineoplastic (bone cancer) & 0.192 & 0.182 \\
\hline & & Antineoplastic antibiotic & 0.139 & 0.035 \\
\hline 9-Hexadecenoic acid, methyl & Antioxidant & Antioxidant & 0.269 & 0.030 \\
\hline & & Free radical scavenger & 0.380 & 0.019 \\
\hline & & Peroxidase substrate & 0.548 & 0.007 \\
\hline & & Reductant & 0.594 & 0.012 \\
\hline & & Lipid peroxidase inhibitor & 0.326 & 0.056 \\
\hline & Antiviral & Antiviral & 0.165 & 0.141 \\
\hline & & Antiviral (Influenza) & 0.492 & 0.024 \\
\hline & & Antiviral (Influenza A) & 0.208 & 0.200 \\
\hline & & Antiviral (Rhinovirus) & 0.639 & 0.004 \\
\hline & & Antiviral (Picornavirus) & 0.497 & 0.052 \\
\hline
\end{tabular}




\begin{tabular}{|c|c|c|c|c|}
\hline & & Antiviral (Adenovirus) & 0.387 & 0.035 \\
\hline & & Antiviral (CMV) & 0.488 & 0.003 \\
\hline & & Antiviral (Herpes) & 0.415 & 0.029 \\
\hline & & $\begin{array}{l}\text { Antiviral (Herpesvirus 3, } \\
\text { Human) }\end{array}$ & 0.013 & 0.006 \\
\hline & & Antiviral (Hepatitis B) & 0.181 & 0.114 \\
\hline & & Antiviral (Parainfluenza) & 0.049 & 0.023 \\
\hline & Anticancer & $\begin{array}{l}\text { Antineoplastic (non-Hodgkin's } \\
\text { lymphoma) }\end{array}$ & 0.425 & 0.086 \\
\hline & & $\begin{array}{l}\text { Antineoplastic (endocrine } \\
\text { cancer) }\end{array}$ & 0.163 & 0.102 \\
\hline & & Antineoplastic (thyroid cancer) & 0.197 & 0.034 \\
\hline & & Antineoplastic, alkylator & 0.189 & 0.021 \\
\hline & & Antineoplastic antimetabolite & 0.148 & 0.050 \\
\hline & & Antineoplastic (liver cancer) & 0.273 & 0.030 \\
\hline & & Antineoplastic (solid tumors) & 0.244 & 0.145 \\
\hline & & Antineoplastic (lymphoma) & 0.137 & 0.125 \\
\hline & & Antineoplastic antibiotic & 0.090 & 0.054 \\
\hline Hexadecanoic acid, methyl & Antioxidant & Antioxidant & 0.210 & 0.050 \\
\hline & & Free radical scavenger & 0.332 & 0.025 \\
\hline & & Peroxidase substrate & 0.424 & 0.017 \\
\hline & & Reductant & 0.523 & 0.020 \\
\hline & & Lipid peroxidase inhibitor & 0.292 & 0.067 \\
\hline & Antiviral & Antiviral & 0.176 & 0.125 \\
\hline & & Antiviral (Influenza) & 0.417 & 0.041 \\
\hline & & Antiviral (Influenza A) & 0.227 & 0.145 \\
\hline & & Antiviral (Rhinovirus) & 0.616 & 0.005 \\
\hline & & Antiviral (Picornavirus) & 0.554 & 0.031 \\
\hline & & Antiviral (Adenovirus) & 0.425 & 0.020 \\
\hline & & Antiviral (CMV) & 0.438 & 0.004 \\
\hline & & Antiviral (Herpes) & 0.392 & 0.039 \\
\hline
\end{tabular}




\begin{tabular}{|c|c|c|c|c|}
\hline & & $\begin{array}{l}\text { Antiviral (Herpesvirus 3, } \\
\text { Human) }\end{array}$ & 0.012 & 0.008 \\
\hline & & Antiviral (Hepatitis B) & 0.219 & 0.070 \\
\hline & & Antiviral (Poxvirus) & 0.352 & 0.039 \\
\hline & & Antiviral (Parainfluenza) & 0.072 & 0.009 \\
\hline & Anticancer & $\begin{array}{l}\text { Antineoplastic (non-Hodgkin's } \\
\text { lymphoma) }\end{array}$ & 0.409 & 0.099 \\
\hline & & $\begin{array}{l}\text { Antineoplastic (endocrine } \\
\text { cancer) }\end{array}$ & 0.214 & 0.038 \\
\hline & & Antineoplastic (bone cancer) & 0.220 & 0.094 \\
\hline & & Antineoplastic (thyroid cancer) & 0.222 & 0.019 \\
\hline & & Antineoplastic, alkylator & 0.218 & 0.016 \\
\hline & & Antineoplastic antimetabolite & 0.205 & 0.032 \\
\hline & & Antineoplastic (liver cancer) & 0.215 & 0.069 \\
\hline & & Antineoplastic (solid tumors) & 0.238 & 0.154 \\
\hline & & Antineoplastic (sarcoma) & 0.165 & 0.117 \\
\hline & & Antineoplastic (bladder cancer) & 0.156 & 0.117 \\
\hline & & Antineoplastic (insulinoma) & 0.012 & 0.009 \\
\hline 1-Heneicosanol & Antioxidant & Antioxidant & 0.229 & 0.043 \\
\hline & & Free radical scavenger & 0.265 & 0.040 \\
\hline & & Peroxidase substrate & 0.630 & 0.004 \\
\hline & & Reductant & 0.731 & 0.005 \\
\hline & & Lipid peroxidase inhibitor & 0.504 & 0.016 \\
\hline & Antiviral & Antiviral & 0.202 & 0.094 \\
\hline & & Antiviral (Influenza) & 0.516 & 0.020 \\
\hline & & Antiviral (Influenza A) & 0.286 & 0.052 \\
\hline & & Antiviral (Rhinovirus) & 0.642 & 0.004 \\
\hline & & Antiviral (Picornavirus) & 0.666 & 0.009 \\
\hline & & Antiviral (Adenovirus) & 0.528 & 0.004 \\
\hline & & Antiviral (CMV) & 0.489 & 0.003 \\
\hline & & Antiviral (Herpes) & 0.442 & 0.020 \\
\hline
\end{tabular}




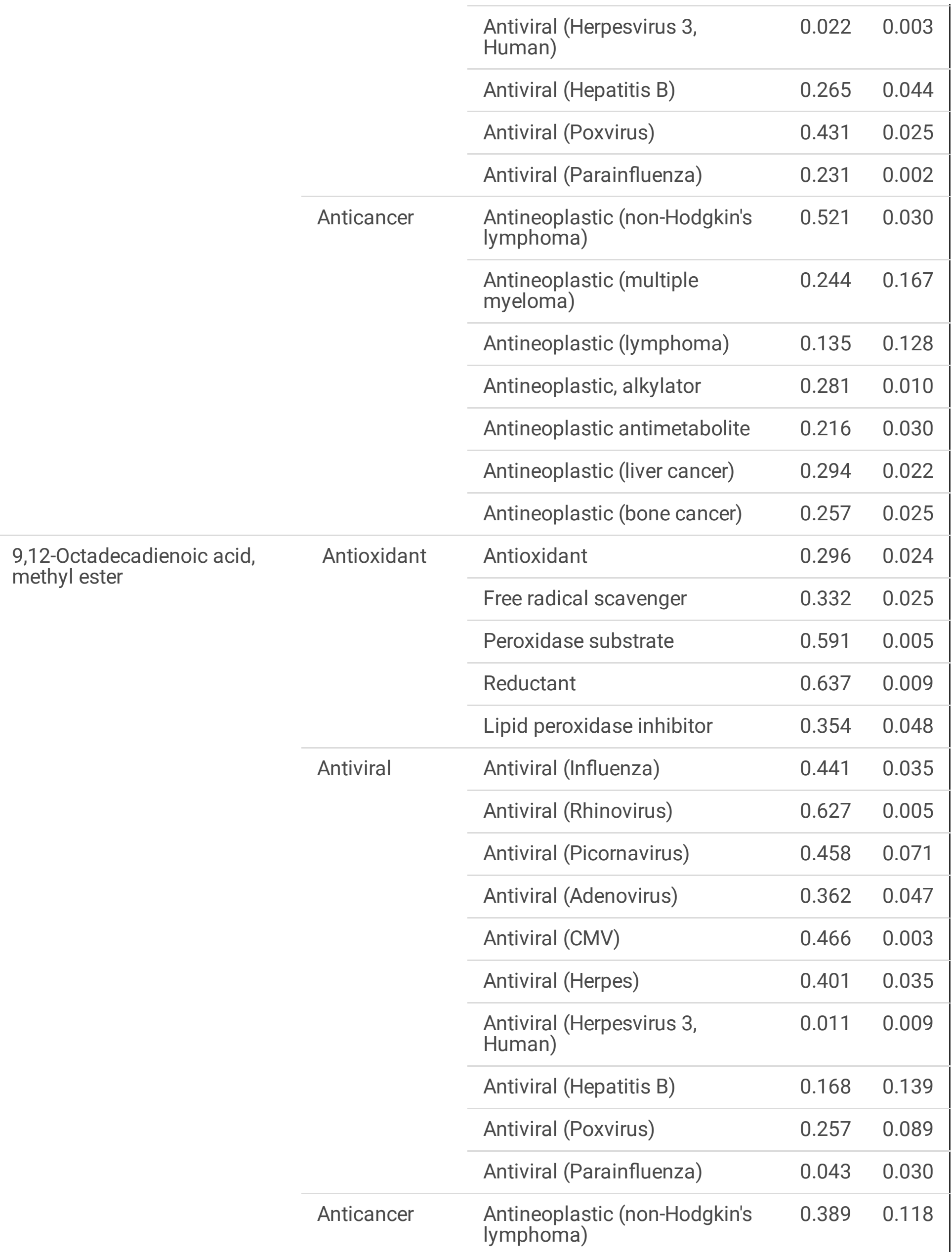









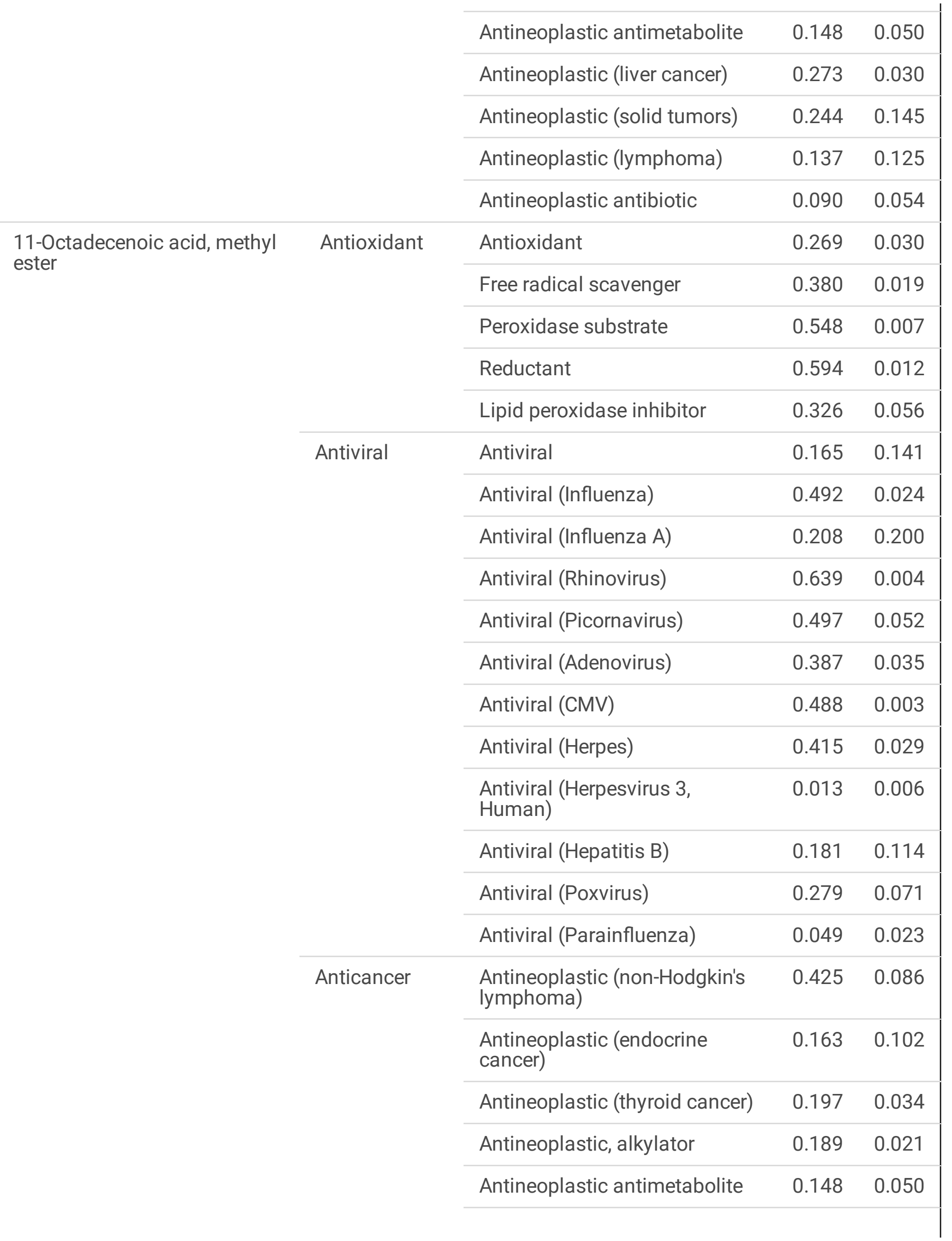




\begin{tabular}{|c|c|c|c|c|}
\hline & & Antineoplastic (liver cancer) & 0.273 & 0.030 \\
\hline & & Antineoplastic (solid tumors) & 0.244 & 0.145 \\
\hline & & Antineoplastic (lymphoma) & 0.137 & 0.125 \\
\hline & & Antineoplastic antibiotic & 0.090 & 0.054 \\
\hline & & Antineoplastic antibiotic & 0.639 & 0.004 \\
\hline Methyl stearate & Antioxidant & Antioxidant & 0.210 & 0.050 \\
\hline & & Free radical scavenger & 0.332 & 0.025 \\
\hline & & Peroxidase substrate & 0.424 & 0.017 \\
\hline & & Reductant & 0.523 & 0.020 \\
\hline & & Lipid peroxidase inhibitor & 0.292 & 0.067 \\
\hline & Antiviral & Antiviral & 0.176 & 0.125 \\
\hline & & Antiviral (Influenza) & 0.417 & 0.041 \\
\hline & & Antiviral (Influenza A) & 0.227 & 0.145 \\
\hline & & Antiviral (Rhinovirus) & 0.616 & 0.005 \\
\hline & & Antiviral (Picornavirus) & 0.554 & 0.031 \\
\hline & & Antiviral (Adenovirus) & 0.425 & 0.020 \\
\hline & & Antiviral (CMV) & 0.438 & 0.004 \\
\hline & & Antiviral (Herpes) & 0.392 & 0.039 \\
\hline & & $\begin{array}{l}\text { Antiviral (Herpesvirus 3, } \\
\text { Human) }\end{array}$ & 0.012 & 0.008 \\
\hline & & Antiviral (Hepatitis B) & 0.219 & 0.070 \\
\hline & & Antiviral (Poxvirus) & 0.352 & 0.039 \\
\hline & & Antiviral (Parainfluenza) & 0.072 & 0.009 \\
\hline & Anticancer & $\begin{array}{l}\text { Antineoplastic (non-Hodgkin's } \\
\text { lymphoma) }\end{array}$ & 0.409 & 0.099 \\
\hline & & $\begin{array}{l}\text { Antineoplastic (endocrine } \\
\text { cancer) }\end{array}$ & 0.214 & 0.038 \\
\hline & & Antineoplastic (thyroid cancer) & 0.222 & 0.019 \\
\hline & & Antineoplastic, alkylator & 0.218 & 0.016 \\
\hline & & Antineoplastic antimetabolite & 0.205 & 0.032 \\
\hline & & Antineoplastic (liver cancer) & 0.215 & 0.069 \\
\hline
\end{tabular}




\begin{tabular}{|c|c|c|c|c|}
\hline & & Antineoplastic (solid tumors) & 0.238 & 0.154 \\
\hline & & Antineoplastic (insulinoma) & 0.012 & 0.009 \\
\hline & & Antineoplastic (bone cancer) & 0.220 & 0.094 \\
\hline & & Antineoplastic (sarcoma) & 0.165 & 0.117 \\
\hline & & Antineoplastic (Bladder cancer) & 0.156 & 0.117 \\
\hline Nonacos-1-ene & Antioxidant & Antioxidant & 0.282 & 0.027 \\
\hline & & Free radical scavenger & 0.286 & 0.034 \\
\hline & & Peroxidase substrate & 0.468 & 0.012 \\
\hline & & Reductant & 0.461 & 0.033 \\
\hline & & Lipid peroxidase inhibitor & 0.364 & 0.046 \\
\hline & Antiviral & Antiviral & 0.197 & 0.099 \\
\hline & & Antiviral (Influenza) & 0.396 & 0.048 \\
\hline & & Antiviral (Rhinovirus) & 0.651 & 0.004 \\
\hline & & Antiviral (Picornavirus) & 0.542 & 0.035 \\
\hline & & Antiviral (Adenovirus) & 0.417 & 0.023 \\
\hline & & Antiviral (CMV) & 0.512 & 0.002 \\
\hline & & Antiviral (Herpes) & 0.417 & 0.028 \\
\hline & & $\begin{array}{l}\text { Antiviral (Herpesvirus 3, } \\
\text { Human) }\end{array}$ & 0.023 & 0.003 \\
\hline & & Antiviral (Hepatitis) & 0.169 & 0.023 \\
\hline & & Antiviral (Poxvirus) & 0.279 & 0.071 \\
\hline & & Antiviral (Parainfluenza) & 0.076 & 0.008 \\
\hline & Anticancer & Antineoplastic (ovarian cancer) & 0.150 & 0.059 \\
\hline & & $\begin{array}{l}\text { Antineoplastic (pancreatic } \\
\text { cancer) }\end{array}$ & 0.281 & 0.074 \\
\hline & & Antineoplastic (thyroid cancer) & 0.214 & 0.023 \\
\hline & & $\begin{array}{l}\text { Antineoplastic (endocrine } \\
\text { cancer) }\end{array}$ & 0.216 & 0.037 \\
\hline & & Antineoplastic (cervical cancer) & 0.177 & 0.050 \\
\hline & & Antineoplastic, alkylator & 0.128 & 0.049 \\
\hline
\end{tabular}




\begin{tabular}{|c|c|c|c|c|}
\hline & & $\begin{array}{l}\text { Antineoplastic (pancreatic } \\
\text { cancer) }\end{array}$ & 0.281 & 0.074 \\
\hline & & Antineoplastic antimetabolite & 0.134 & 0.059 \\
\hline & & Antineoplastic (liver cancer) & 0.263 & 0.035 \\
\hline n-Heptadecanol-1 & Antioxidant & Antioxidant & 0.229 & 0.043 \\
\hline & & Free radical scavenger & 0.265 & 0.040 \\
\hline & & Peroxidase substrate & 0.630 & 0.004 \\
\hline & & Reductant & 0.731 & 0.005 \\
\hline & & Lipid peroxidase inhibitor & 0.504 & 0.016 \\
\hline & Antiviral & Antiviral & 0.202 & 0.094 \\
\hline & & Antiviral (Influenza) & 0.516 & 0.020 \\
\hline & & Antiviral (Influenza A) & 0.286 & 0.052 \\
\hline & & Antiviral (Rhinovirus) & 0.642 & 0.004 \\
\hline & & Antiviral (Picornavirus) & 0.666 & 0.009 \\
\hline & & Antiviral (Adenovirus) & 0.528 & 0.004 \\
\hline & & Antiviral (CMV) & 0.489 & 0.003 \\
\hline & & Antiviral (Herpes) & 0.442 & 0.020 \\
\hline & & $\begin{array}{l}\text { Antiviral (Herpesvirus 3, } \\
\text { Human) }\end{array}$ & 0.022 & 0.003 \\
\hline & & Antiviral (Hepatitis B) & 0.265 & 0.044 \\
\hline & & Antiviral (Poxvirus) & 0.431 & 0.025 \\
\hline & & Antiviral (Parainfluenza) & 0.231 & 0.002 \\
\hline & Anticancer & $\begin{array}{l}\text { Antineoplastic (non-Hodgkin's } \\
\text { lymphoma) }\end{array}$ & 0.521 & 0.030 \\
\hline & & $\begin{array}{l}\text { Antineoplastic (multiple } \\
\text { myeloma) }\end{array}$ & 0.244 & 0.167 \\
\hline & & Antineoplastic (lymphoma) & 0.135 & 0.128 \\
\hline & & Antineoplastic, alkylator & 0.281 & 0.010 \\
\hline & & Antineoplastic antimetabolite & 0.216 & 0.030 \\
\hline & & Antineoplastic (liver cancer) & 0.294 & 0.022 \\
\hline & & Antineoplastic (bone cancer) & 0.257 & 0.025 \\
\hline
\end{tabular}




\section{Table 10}

Correlation coefficients between the total phenolic contents and antioxidant as well as HeLa cell proliferation.

\begin{tabular}{|c|c|c|c|c|c|c|}
\hline \multirow[b]{2}{*}{ Assays } & \multicolumn{6}{|c|}{ Total Phenolic Contents (Correlation $\mathrm{R}^{2}$ ) } \\
\hline & DPPH & Hydroxyl & Lipid Peroxide & TAC & FRPC & MTT \\
\hline CME & 0.55856 & $0.93479^{\star \star}$ & $0.89227^{*}$ & $0.9888^{\star \star \star}$ & $0.90741^{*}$ & $0.99414^{*}$ \\
\hline PEF & 1.9483 & $0.97567^{\star \star}$ & $0.9105^{\star}$ & $0.92046^{\star \star}$ & $0.97598^{\star *}$ & 0.92154 \\
\hline $\mathrm{CHF}$ & $0.14652^{\star \star}$ & $0.95742^{\star \star}$ & $0.88646^{*}$ & $0.97608^{\star \star}$ & $0.99748^{\star \star \star \star}$ & $0.99996^{\star \star}$ \\
\hline EAF & 0.0808 & 0.66511 & $0.8493^{*}$ & $0.99566^{\star \star \star}$ & $0.88279^{*}$ & 0.97599 \\
\hline AQF & 0.8171 & $0.94858^{\star \star}$ & $0.85996^{*}$ & $0.99387^{\star \star \star}$ & $0.99265^{\star \star \star}$ & 0.97742 \\
\hline
\end{tabular}

\section{Table 11}

Correlation coefficients between the total flavonoid contents and antioxidant as well as HeLa cell proliferation.

\section{Total flavonoid contents (Correlation $\mathrm{R}^{2}$ )}

\begin{tabular}{|c|c|c|c|c|c|c|}
\hline Assays & DPPH & Hydroxyl & Lipid Peroxide & TAC & FRPC & MTT \\
\hline CME & 0.55856 & $0.93479^{\star \star}$ & $0.89227^{*}$ & $0.9888^{\star \star \star}$ & $0.90741^{*}$ & $0.99414^{*}$ \\
\hline PEF & 0.66765 & $0.97567^{\star \star}$ & $0.9105^{*}$ & $0.92046^{* \star}$ & $0.97598^{\star *}$ & 0.92154 \\
\hline CHF & $0.97345^{\star \star}$ & $0.95742^{\star \star}$ & $0.88646^{*}$ & $0.97608^{\star \star}$ & $0.99748^{\star \star \star \star}$ & $0.99996^{* *}$ \\
\hline EAF & 0.4918 & 0.66511 & $0.8493^{*}$ & $0.99566^{* \star \star}$ & $0.88279^{* *}$ & 0.97599 \\
\hline AQF & 0.55222 & $0.94858^{* \star}$ & $0.85996^{*}$ & $0.99387^{\star \star \star}$ & $0.99265^{\star \star \star}$ & 0.97742 \\
\hline
\end{tabular}


Figures

Figure 1

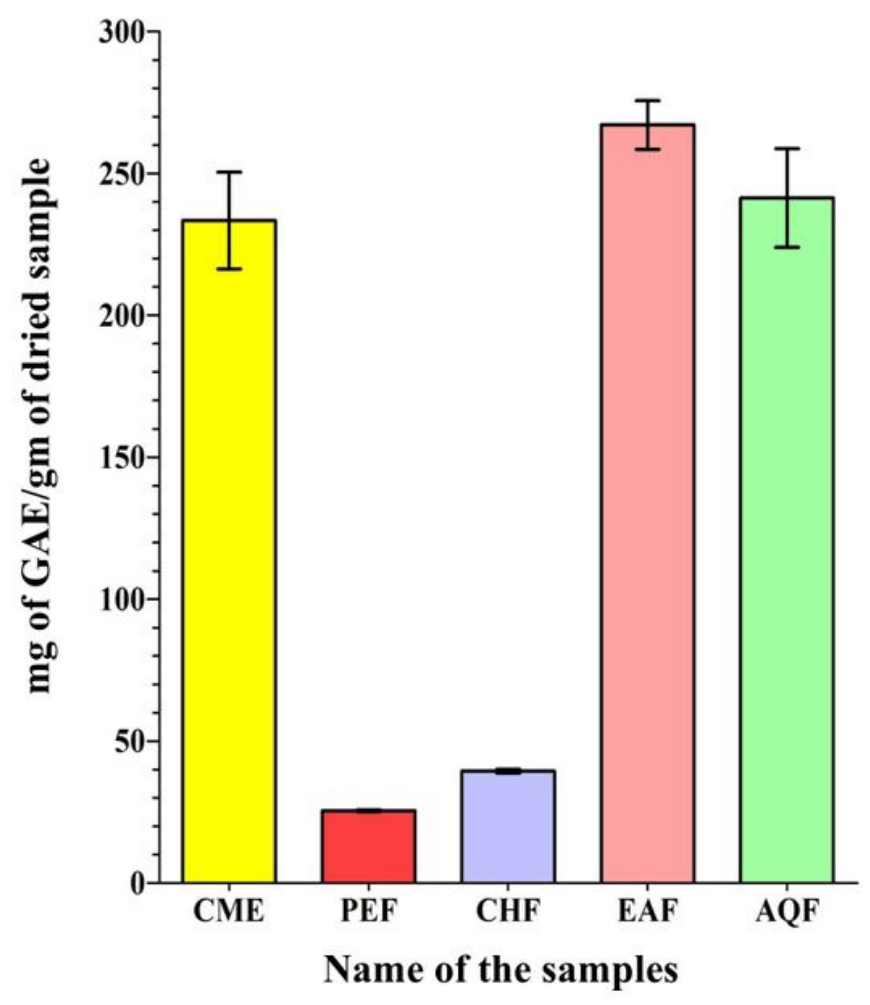

B

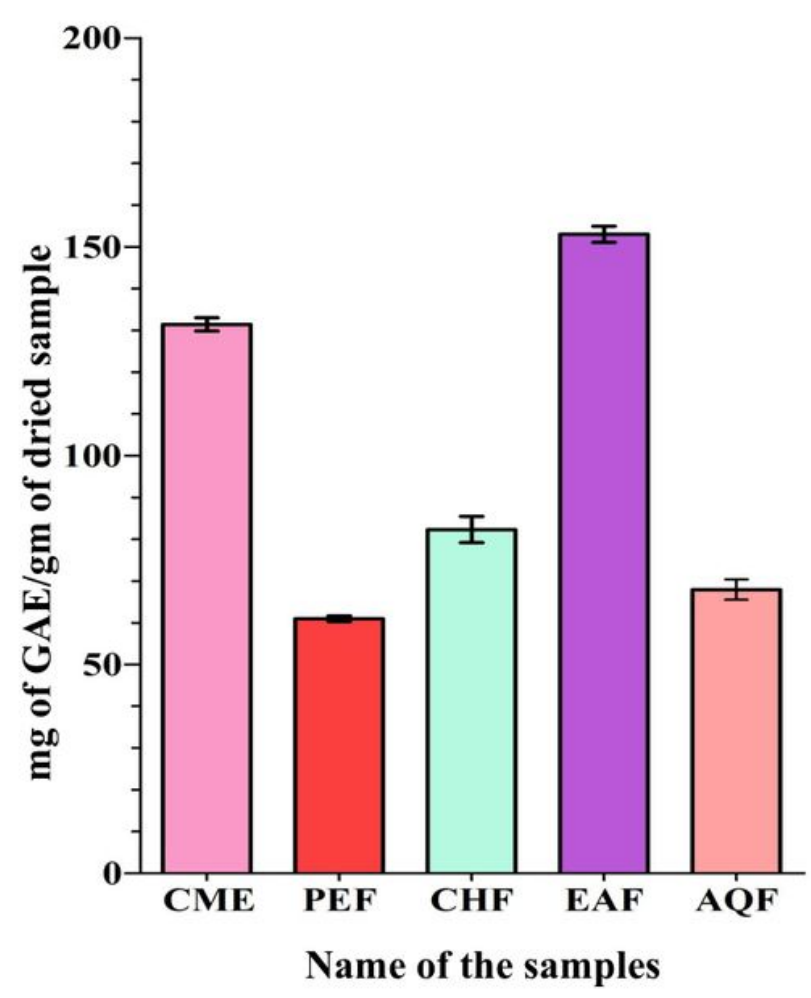

Figure 1

Polyphenolic contents of CME and its different fractions. (A) Total phenolic (mg of GAE/gm of dried sample) and (B) flavonoid contents (mg of CAE/gm of dried sample) of CME and it's four fractions (PEF, $\mathrm{CHF}, \mathrm{EAF}$ and $A Q F)$. Data expressed as mean $\pm \mathrm{SD}(\mathrm{n}=3)$ for all tested dosages. Where, methanolic extract of $L$. aequata (CME), petroleum ether (PEF), chloroform (CHF), ethyl acetate (EAF), and aqueous (AQF) fractions. 
Figure 2

A

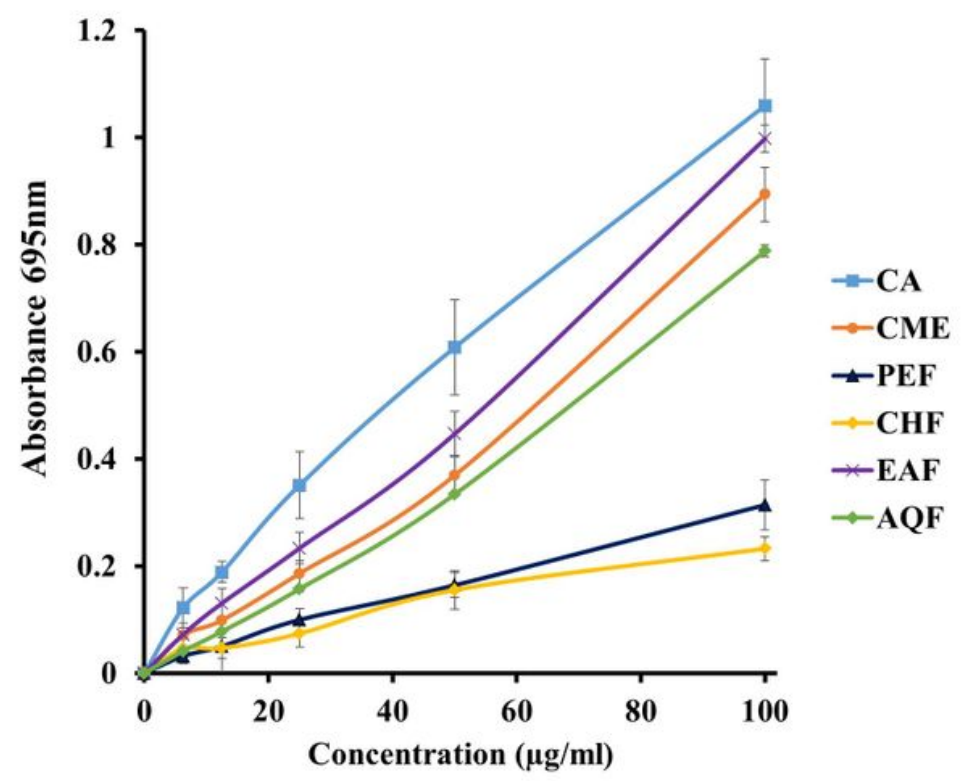

B

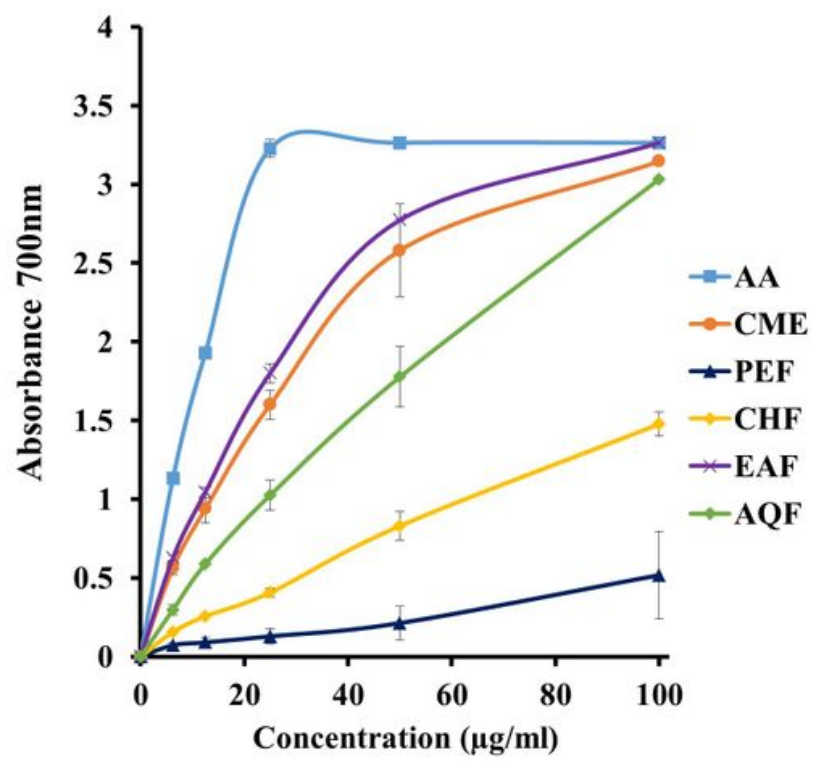

Figure 2

Comparative antioxidant activity of CME and its different fractions. (A) Total antioxidant and (B) Ferrous reducing antioxidant capacity of CME and its four fractions (PEF, CHF, EAF and AQF). Data expressed as mean $\pm S D(n=3)$ for all tested dosages. Where, methanolic extract of $L$. aequata $(C M E)$, petroleum ether $(\mathrm{PEF})$, chloroform (CHF), ethyl acetate (EAF), and aqueous (AQF) fractions. 
Figure 3

A

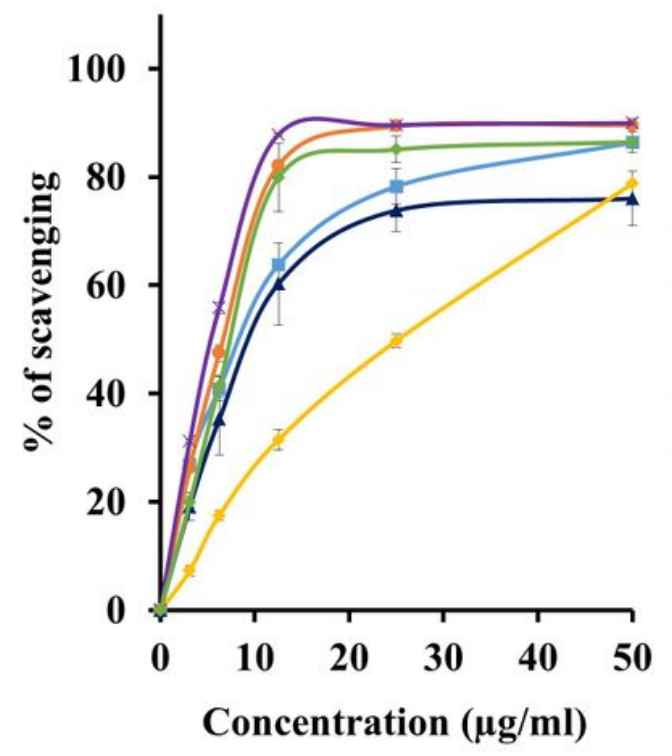

B

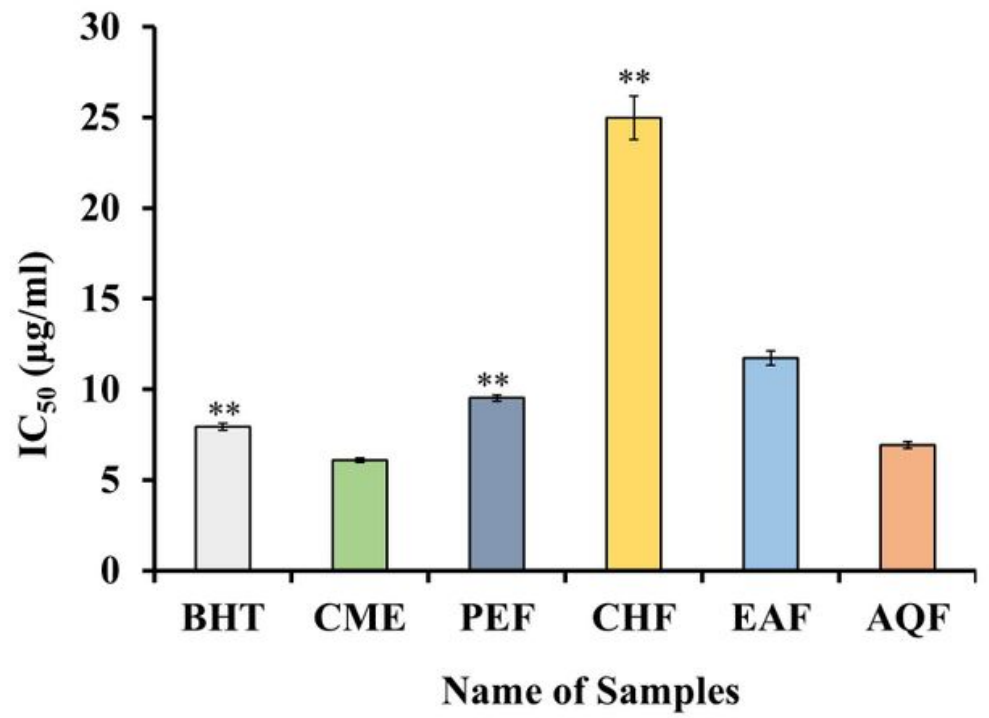

Figure 3

Comparative DPPH free radical scavenging activity of CME and its different fractions. (A) DPPH free radical scavenging and (B) IC50 $(\mu \mathrm{g} / \mathrm{mL})$ values of CME and its four fractions (PEF, CHF, EAF and AQF). Data expressed as mean \pm SD $(n=3)$ for all tested dosages. Values with $\left({ }^{*} p<0.05,{ }^{\star \star} p<0.01\right.$, ${ }^{\star \star \star} p<$ $0.001, * \star \star \star p<0.0001)$ were considered significant. Where, methanolic extract of L. aequata $(\mathrm{CME})$, petroleum ether (PEF), chloroform (CHF), ethyl acetate (EAF), and aqueous (AQF) fractions. 
Figure 4

A

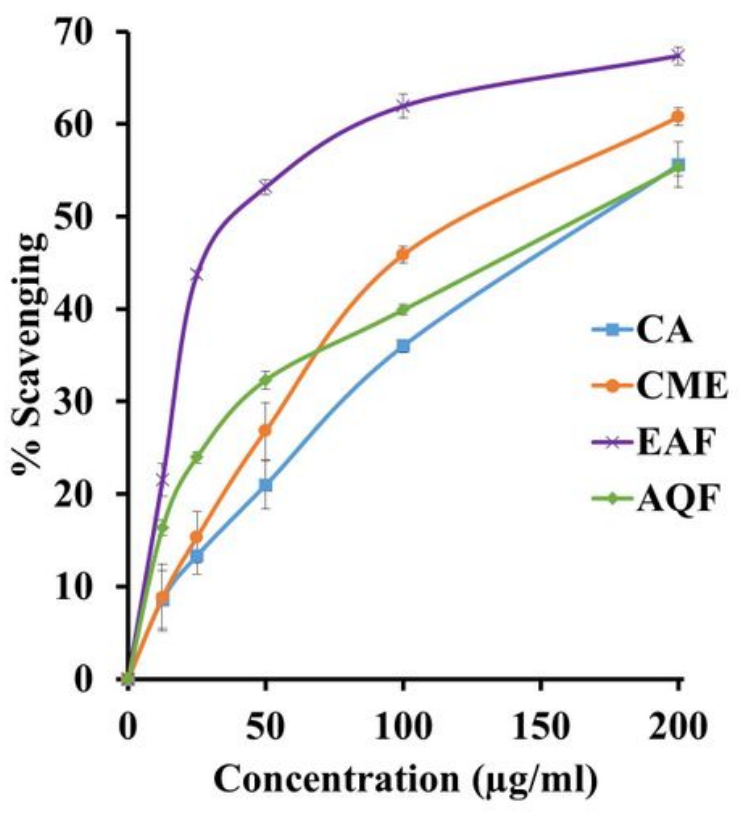

B

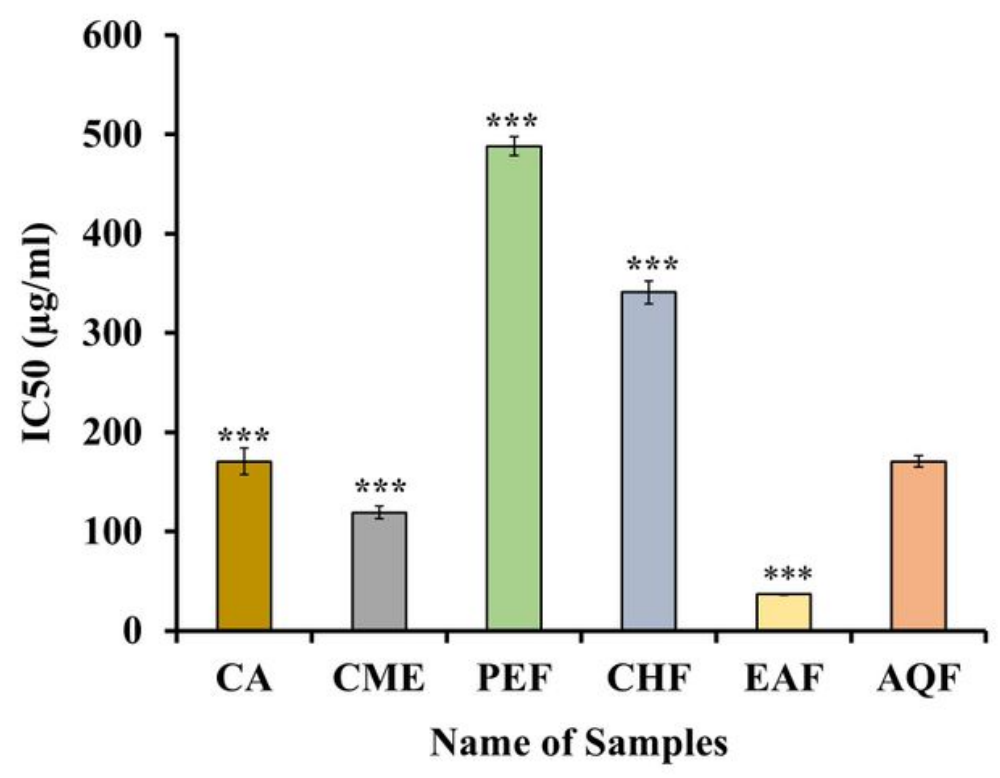

\section{Figure 4}

Comparative hydroxyl radical scavenging activity of $\mathrm{CME}$ and its different fractions. (A) Hydroxyl radical scavenging and $(B) I C 50(\mu \mathrm{g} / \mathrm{mL})$ values of CME and its four fractions (PEF, CHF, EAF and AQF). Data expressed as mean $\pm S D(n=3)$ for all tested dosages. Values with $\left({ }^{\star} p<0.05,{ }^{* \star} p<0.01,{ }^{* \star *} p<0.001\right.$, $\star * \star \star p<0.0001)$ were considered significant. Where, methanolic extract of $L$. aequata $(C M E)$, petroleum ether (PEF), chloroform (CHF), ethyl acetate (EAF), and aqueous (AQF) fractions. 
Figure 5

A

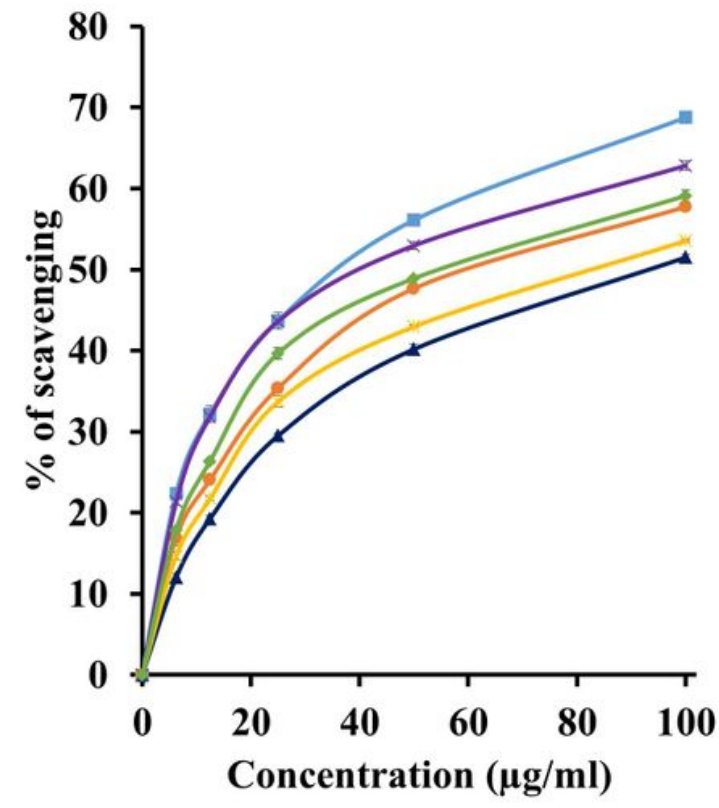

B

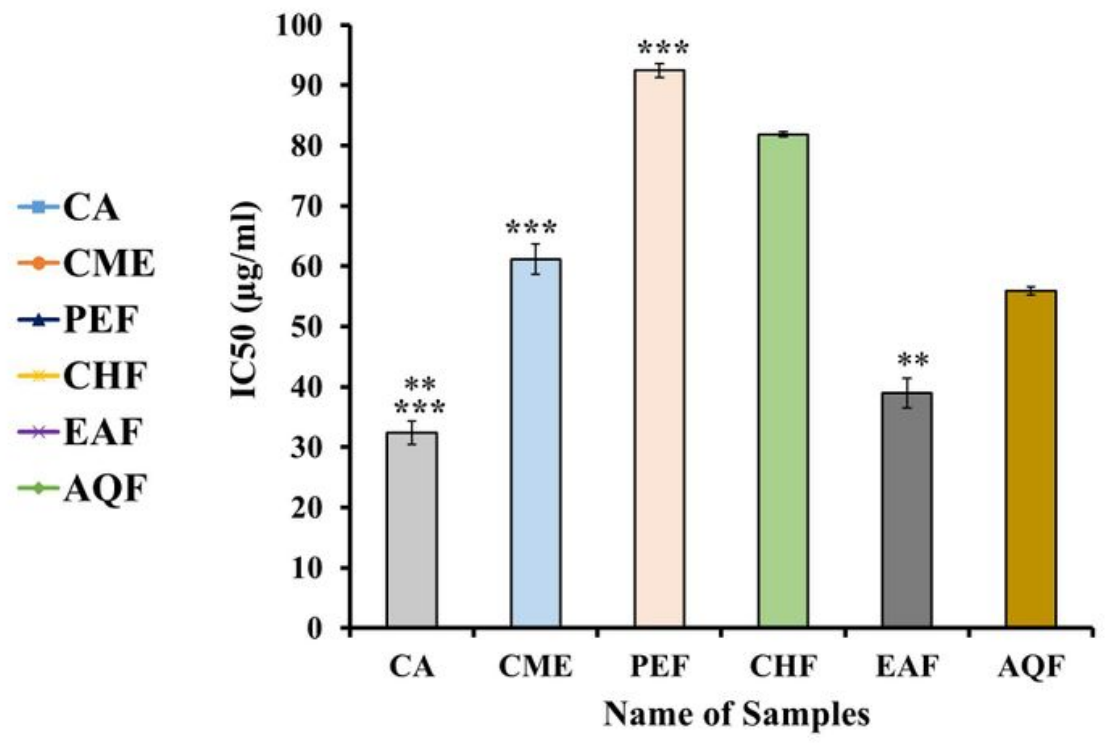

Figure 5

Comparative lipid peroxidation inhibition of CME and its different fraction. (A) Lipid peroxidation inhibition and (B) IC50 $(\mu \mathrm{g} / \mathrm{mL})$ values CME and its four fractions (PEF, CHF, EAF and AQF). Data expressed as mean $\pm S D(n=3)$ for all tested dosages. Values with $\left({ }^{\star} p<0.05,{ }^{* \star} p<0.01,{ }^{* \star *} p<0.001\right.$, $\star \star \star \star p<0.0001)$ were considered significant. Where, methanolic extract of $L$. aequata $(\mathrm{CME})$, petroleum ether (PEF), chloroform (CHF), ethyl acetate (EAF), and aqueous (AQF) fractions. 
Figure 6

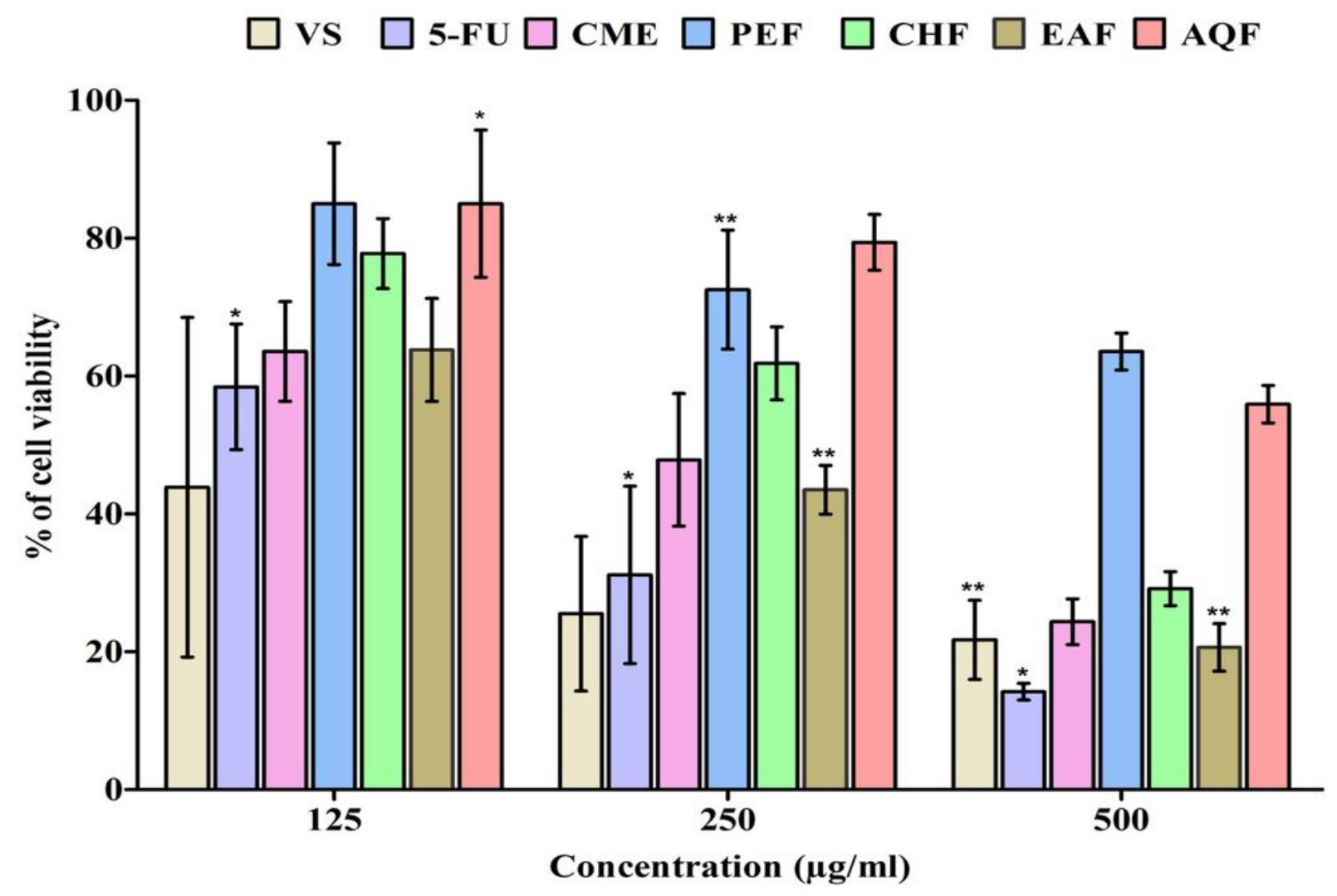

Figure 6

Percent (\%) of viable cells of CME and its four fractions (PEF, CHF, EAF and AQF) of L. aequata leaves on HeLa cells. Data expressed as mean \pm SD $(n=3)$ for all tested dosages.

\section{Figure 7}

A

\section{DAPI}

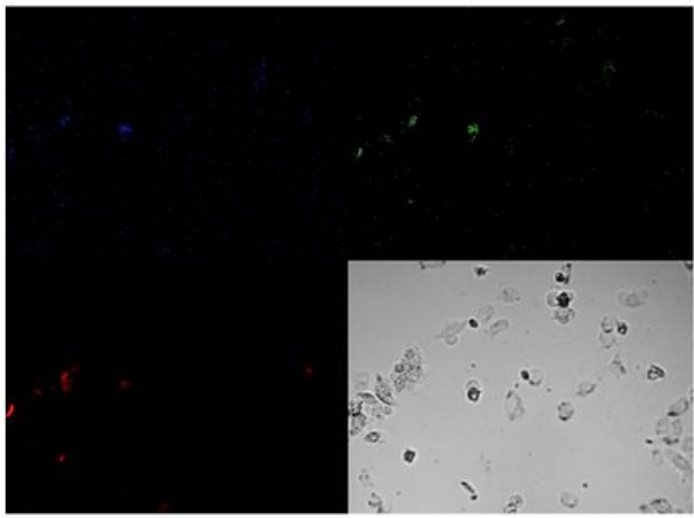

PI
No stain

Untreated HeLa Cells
B

DAPI Anexin-V

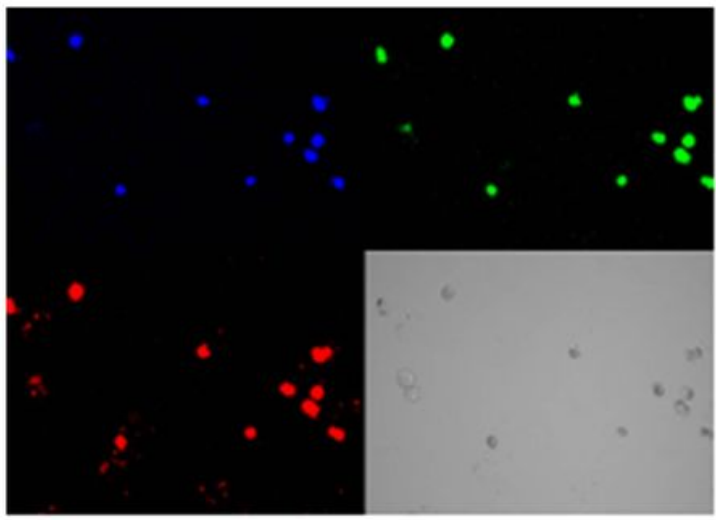

PI

No stain

EAF-treated Cells 
Figure 7

Measurement of apoptosis of EAF of L. aequata leaves on HeLa cells.

\section{Figure 8}

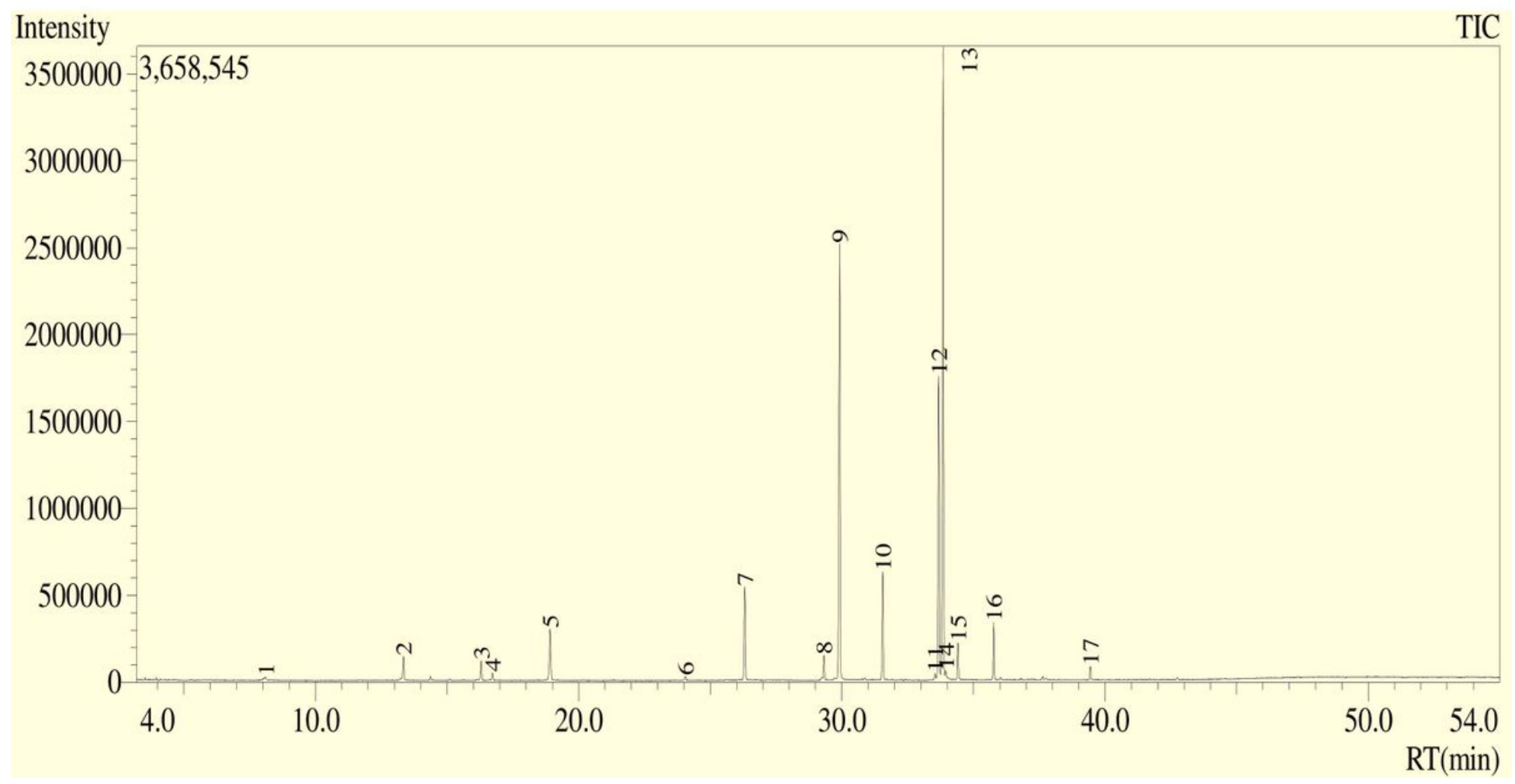

\section{Figure 8}

Gas chromatography-mass spectrometry profile of EAF was obtained from GC-MS with electron impact ionization (EI) method on a gas chromatograph (GC-17A, Shimadzu Corporation, Kyoto, Japan) coupled to a mass spectrometer (GC-MS TQ 8040, Shimadzu Corporation, Kyoto, Japan). 
(A)

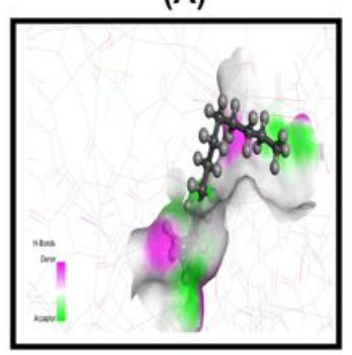

(F)

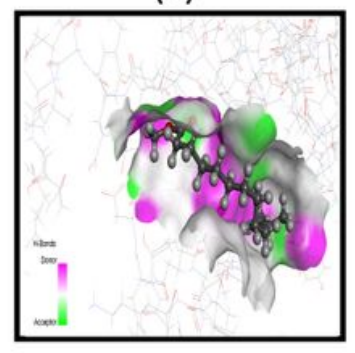

(K)

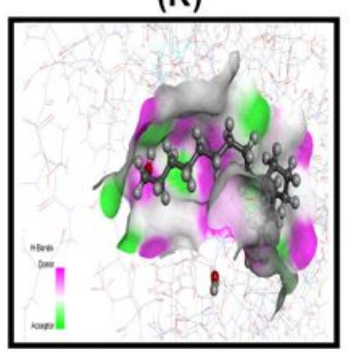

(B)



(G)

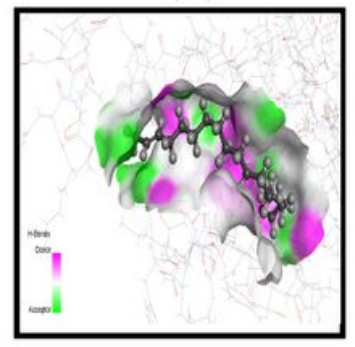

(L)

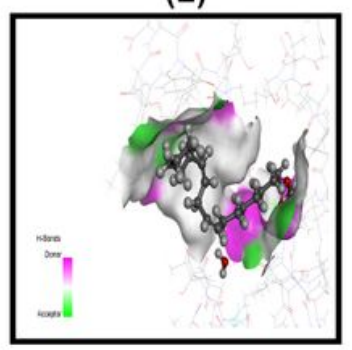

(C)

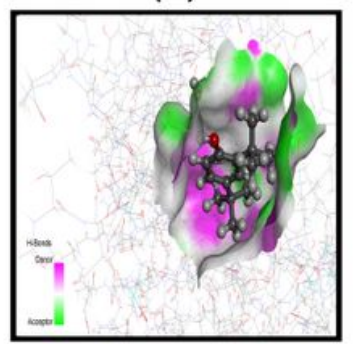

(H)

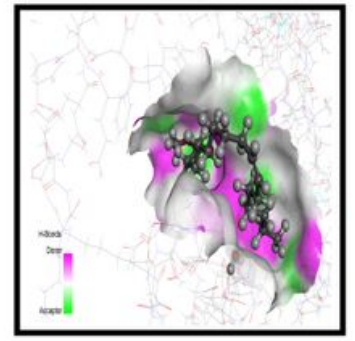

(M)

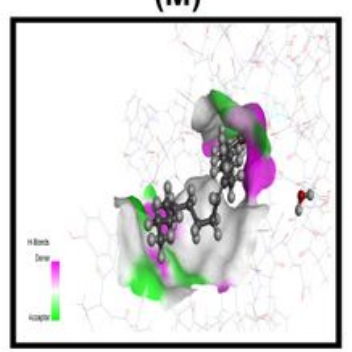

(P)

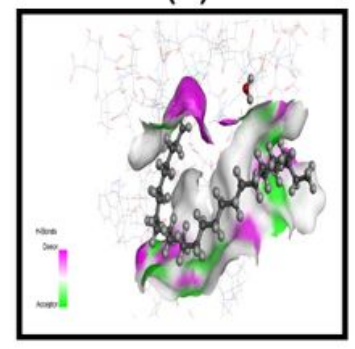

(D)

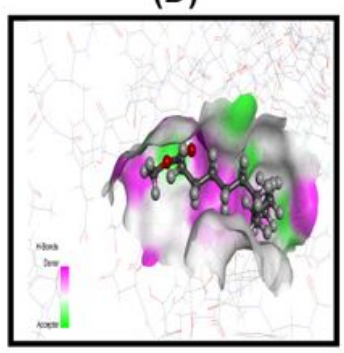

(I)

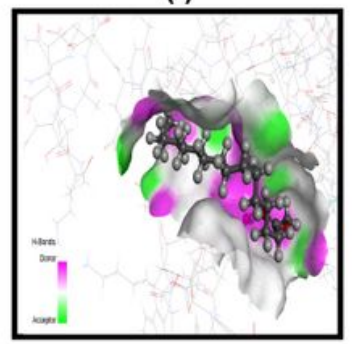

(N)



(Q)

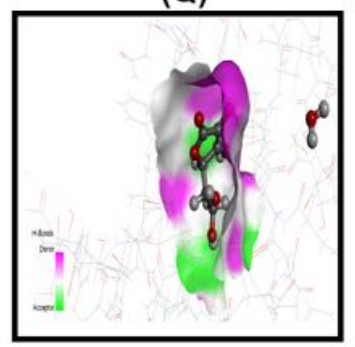

(E)

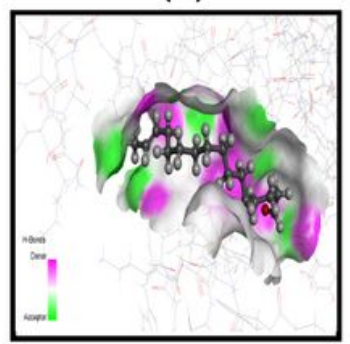

(J)

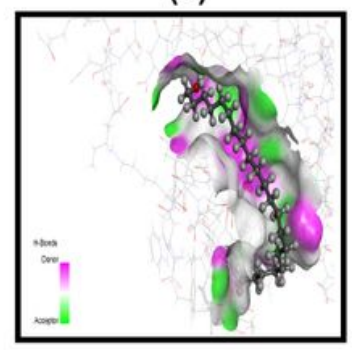

(0)

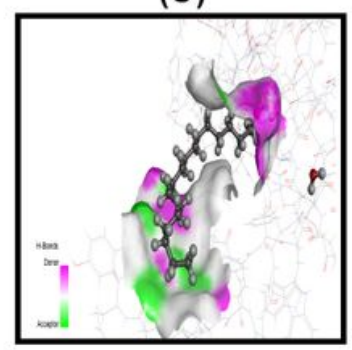

\section{Figure 9}

3D representation of molecular docking simulation between urate oxidase (PDB:1R4U) and (A) Cyclopropane, nonyl-; (B) 1-Tetradecene; (C) Phenol, 2,4-bis(1,1-dimethylethyl)-; (D) Dodecanoic acid, methyl ester; (E) E-14-Hexadecenal; (F) Tridecanoic acid, 12-methyl-, methyl ester; (G) E-15-Heptadecenal; (H) 9-Hexadecenoic acid, methyl ester, (Z)-; (I) Hexadecanoic acid, methyl ester; (J) 1-Heneicosanol; (K) nHeptadecanol-1; (L) 9,12-Octadecadienoic acid, methyl ester; (M) 9-Octadecenoic acid (Z)-, methyl ester; (N) 11-Octadecenoic acid, methyl ester; (O) Methyl stearate; (P) Nonacos-1-ene; (Q) Ascorbic acid. 
(A)

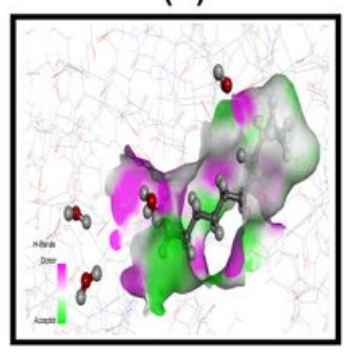

(F)

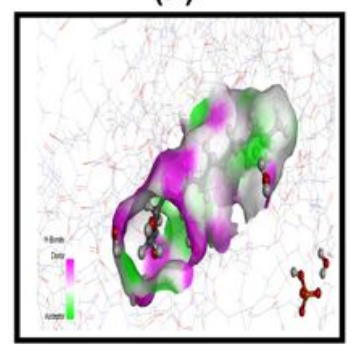

(K)

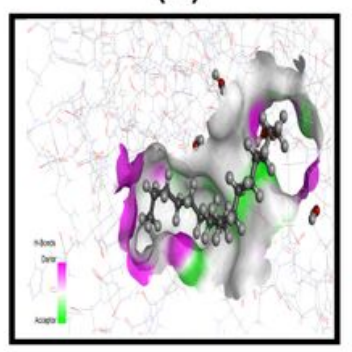

(B)

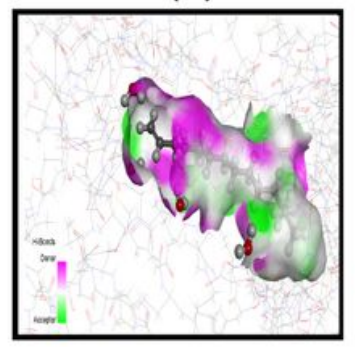

(G)

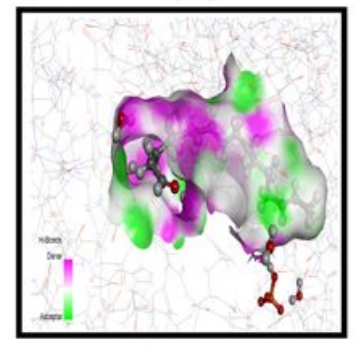

(L)

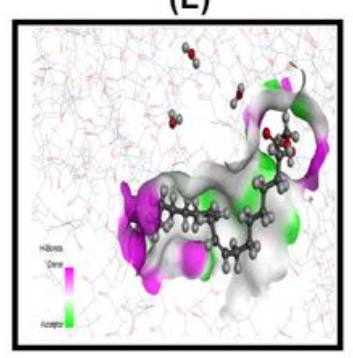

(C)

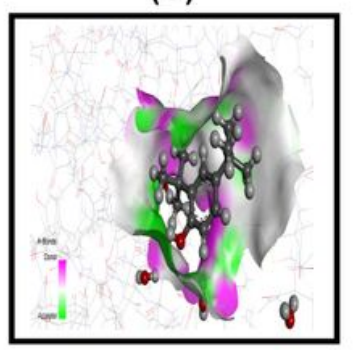

(H)

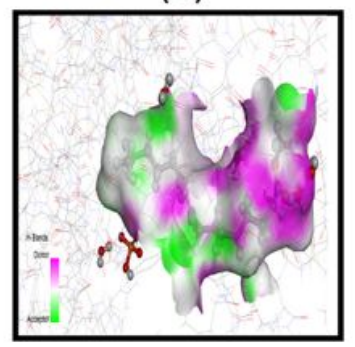

(M)

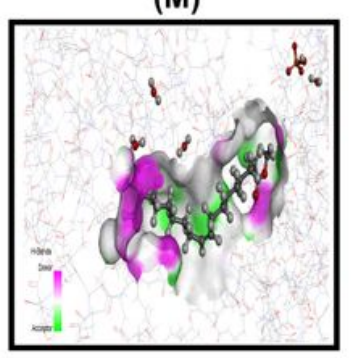

(D)



(I)

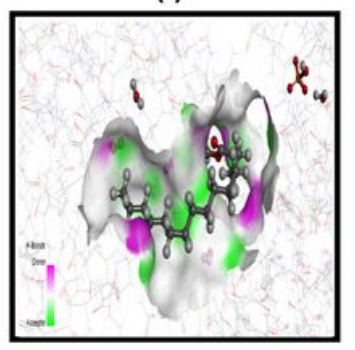

(N)

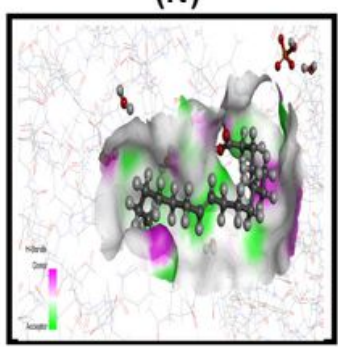

(Q)
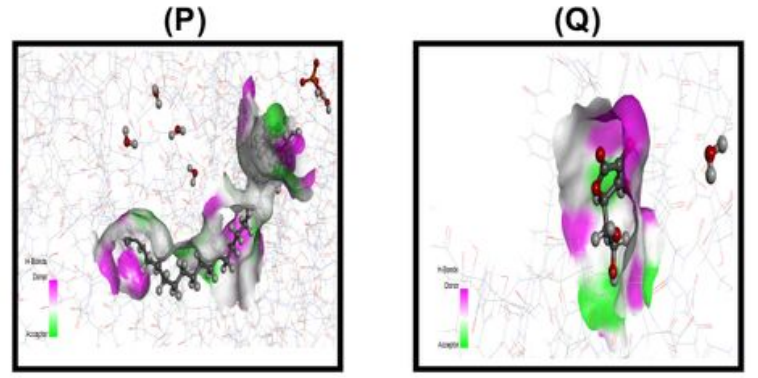

(E)

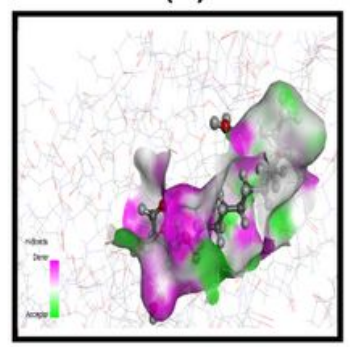

(J)



(0)

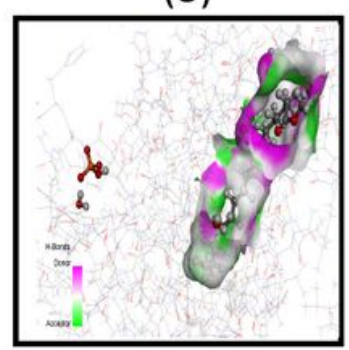

\section{Figure 10}

$3 \mathrm{D}$ representation of molecular docking simulation between glutathione reductase (PDB: 3GRS) and (A) Cyclopropane, nonyl-; (B) 1-Tetradecene; (C) Phenol, 2,4-bis(1,1-dimethylethyl)-; (D) Dodecanoic acid, methyl ester; (E) E-14-Hexadecenal; (F) Tridecanoic acid, 12-methyl-, methyl ester; (G) E-15-Heptadecenal; (H) 9-Hexadecenoic acid, methyl ester, (Z); (I) Hexadecanoic acid, methyl ester; (J) 1-Heneicosanol; (K) nHeptadecanol-1; (L) 9,12-Octadecadienoic acid, methyl ester; (M) 9-Octadecenoic acid (Z)-, methyl ester; (N) 11-Octadecenoic acid, methyl ester; (O) Methyl stearate; (P) Nonacos-1-ene; (Q) Ascorbic acid. 
(A)

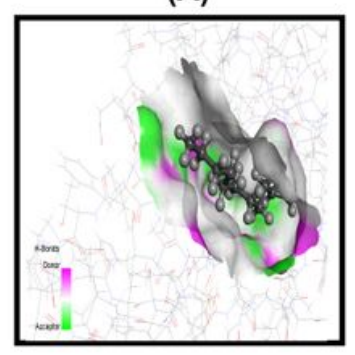

(F)



(K)

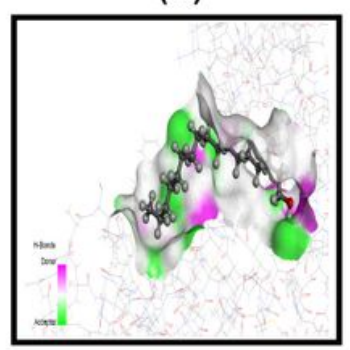

(B)

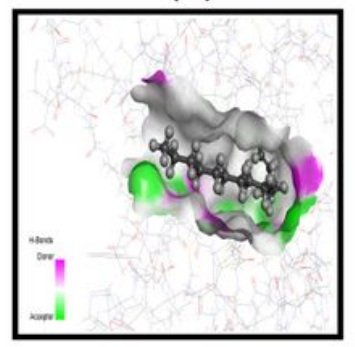

(G)

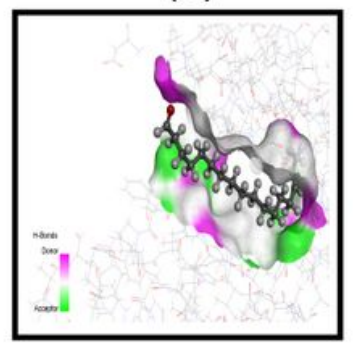

(L)



(C)

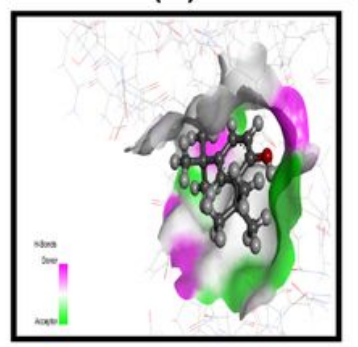

(H)



(M)

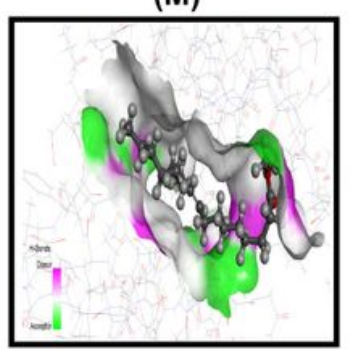

(D)



(I)



(N)



(Q)
(E)

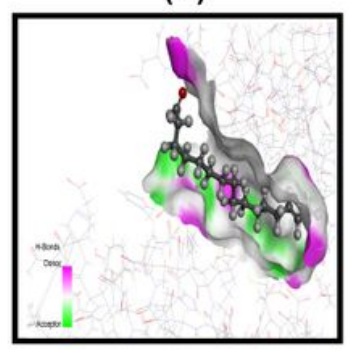

(J)

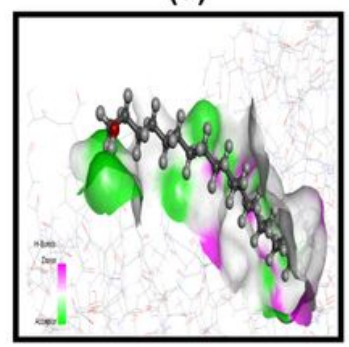

(0)

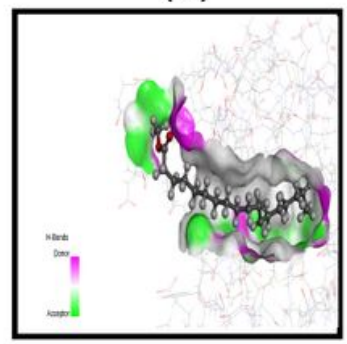

(P)

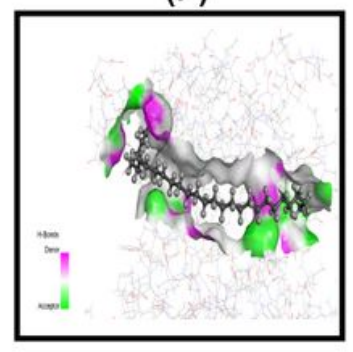

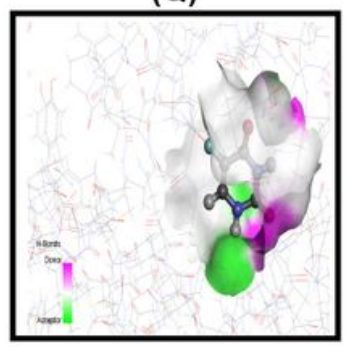

Figure 11

3D representation of molecular docking simulation between EGFR kinase domain (PDB: 2ITY) and (A) Cyclopropane, nonyl-; (B) 1-Tetradecene; (C) Phenol, 2,4-bis(1,1-dimethylethyl)-; (D) Dodecanoic acid, methyl ester; (E) E-14-Hexadecenal; (F) Tridecanoic acid, 12-methyl-, methyl ester; (G) E-15-Heptadecenal; (H) 9-Hexadecenoic acid, methyl ester, (Z); (I) Hexadecanoic acid, methyl ester; (J) 1-Heneicosanol; (K) nHeptadecanol-1; (L) 9,12-Octadecadienoic acid, methyl ester; (M) 9-Octadecenoic acid (Z)-, methyl ester; (N) 11-Octadecenoic acid, methyl ester; $(0)$ Methyl stearate; $(P)$ Nonacos-1-ene; (Q) 5-fluorouracil 
(A)



(F)



(K)

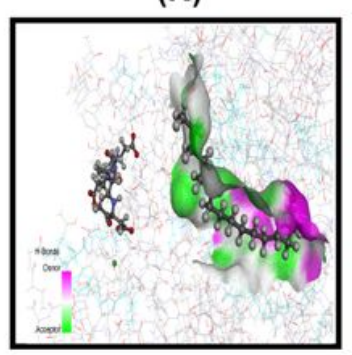

(B)



(G)

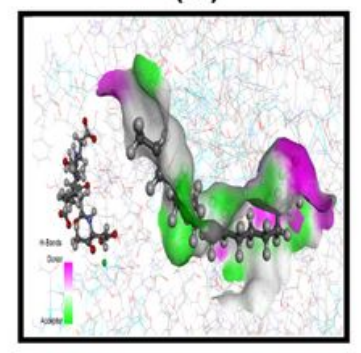

(L)

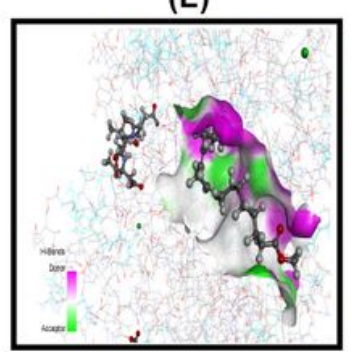

(C)

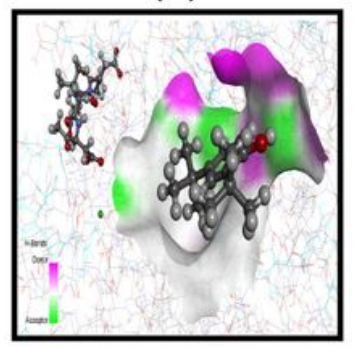

(H)

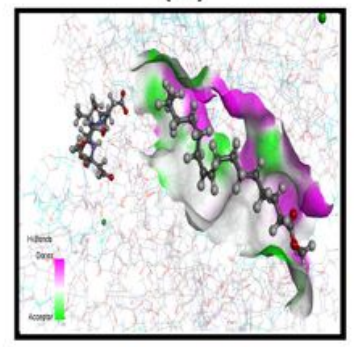

(M)

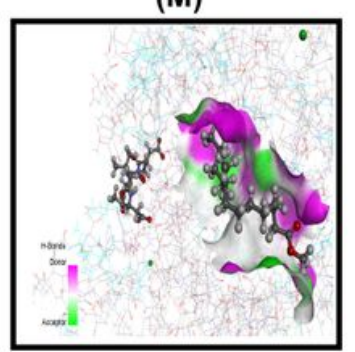

(P)



(D)



(I)

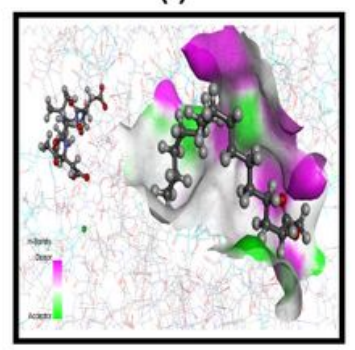

(N)



(Q)



(E)



(J)



(0)

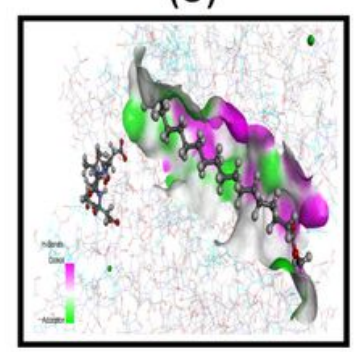

\section{Figure 12}

3D representation of molecular docking simulation between caspase 3 (PDB: 5IAE) and (A) Cyclopropane, nonyl-; (B) 1-Tetradecene; (C) Phenol, 2,4-bis(1,1-dimethylethyl); (D) Dodecanoic acid, methyl ester; (E) E14-Hexadecenal; (F) Tridecanoic acid, 12-methyl-, methyl ester; (G) E-15-Heptadecenal; (H) 9-

Hexadecenoic acid, methyl ester, (Z)-; (I) Hexadecanoic acid, methyl ester; (J) 1-Heneicosanol; (K) nHeptadecanol-1; (L) 9,12-Octadecadienoic acid, methyl ester; (M) 9-Octadecenoic acid (Z)-, methyl ester; (N) 11-Octadecenoic acid, methyl ester; $(\mathrm{O})$ Methyl stearate; $(\mathrm{P})$ Nonacos-1-ene; $(\mathrm{Q})$ 5-fluorouracil 